\title{
La responsabilidad internacional del transportista aéreo en caso de muerte o lesión de pasajeros: 'forum shopping' y futuro del Convenio de Montreal de 1999. Análisis jurídico y económico
}

\author{
Santiago Areal Ludeña \\ Profesor titular de Derecho Internacional Privado \\ Universidad Carlos III de Madrid \\ $\mathrm{y}$ \\ Jorge Alberto Fierro Abella \\ Doctorando en Derecho Privado \\ Universidad Carlos III de Madrid
}

Recibido: 09.02.09

Aceptado: 04.05.09

Resumen: Lo que años después se denominó el Sistema de Varsovia alcanzó un nivel considerable de insatisfacción entre académicos y aplicadores del Derecho, debido principalmente a la disparidad de textos legales y a la diversidad interpretativa. Tales falencias proporcionaron un escenario ideal para un litigio desafortunado, fenómeno descrito como forum shopping. La comunidad internacional se apresuró en la búsqueda de una solución, la cual parecía proveer un nuevo texto internacional. La respuesta vino con la Convención de Montreal de 1999. No obstante, discrepante conceptualización de rubros del daño entre los países de Derecho Civil Codificado y del Common Law, terminó por reintroducir un nuevo reto a la estandarización perseguida por la Convención. El análisis debe incluir los diversos modelos de responsabilidad previstos para los supuestos de muerte y lesión de pasajeros, por cuanto las soluciones difieren según el riesgo creado por el transportista aéreo internacional de pasajeros se base en culpa o en intención. Con el objetivo de evitar teorizaciones innecesarias, en consideración a que la Convención es norma en sentido material, cualquier estudio del ejercicio legal deberá basarse en su literalidad. A su vez, el análisis económico de la jurisprudencia invita a juristas a aceptar su validez en la corrección de los modelos legales, así como en la aprehensión de los principios y valores del Instrumento Internacional. El presente trabajo busca, en efecto, compatibilizar los métodos jurídico y económico desde una perspectiva comparativa; para determinar el futuro de la Convención, sus aciertos y fracasos.

Palabras clave: Sistema de Varsovia, forum shopping, Convenio de Montreal de 1999.

Abstract: What after years became the so-called Varsovia System reached a level of insatisfaction among academics and law applicants, due to the disparity of legal instruments and diverse interpretation. The gaps provided an ideal scenario for malpractice of litigation, a phenomenon described as forum shopping. International Community rushed to reach a solution that a new International Law seemed to provide. The answers came with the Convention of Montreal 1999. Nevertheless, the discrepant conceptualization of damage between codified-civil- 
law and Common Law countries introduced a new challenge to the standardization pursued by the Convention. The analysis must be extended to the various models of liability given to the cases of death and injury of passengers, as solutions differ whether the risk created by international air carriers of passengers is based on fault, strict liability and intention. As a mean to prevent unnecessary further theorization, any research of law application should be based on the literalness of the Convention. Economic interpretation of jurisprudence welcomes jurists to accept a unique point of view in the correction of the legal models and the apprehension of the principles and values of the Instrument. The following text attempts to make legal and economic methodologies compatible under comparative grounds; in order to determine the future of the Convention, its achievements and failures.

Key words: Varsovia System, forum shopping, Convention of Montreal 1999.

\section{Sumario:}

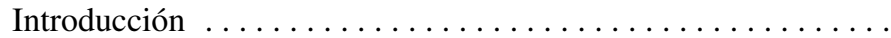

1. Del carácter internacional del transporte aéreo ...........

2. Reseña histórica: del Sistema de Varsovia al Convenio de Montreal de 1999 .............................

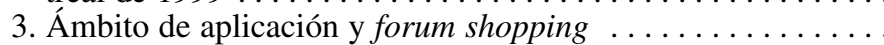

4. Descripción normativa y reglas de responsabilidad: del SV al CM 1999 . . . . . . . . . . . . . . . . . . . . . . . . . . .

4.1. Responsabilidad objetiva ...................

4.2. Responsabilidad limitada $\ldots \ldots \ldots \ldots \ldots \ldots \ldots$

4.3. Supuestos no regulados por la norma convencional .....

4.3.1. Conflictualismo frente a legeforismo ..........

4.3.2. Supuestos de responsabilidad del transportista aéreo internacional no regulados en los regímenes

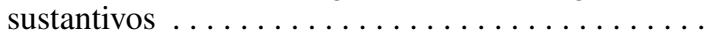

5. Análisis económico del daño intencional .............

5.1. Introducción al análisis económico de la responsabilidad .

5.2. Hacia una definición económica de intencionalidad ....

5.2.1. Consciencia del siniestro, pero sin Ánimo de causación ni deseo de lucro consecuencial ..........

5.2.2. Ánimo de provocar un resultado dañino, pero sin consciencia de ilegitimidad ................

5.2.3. Ánimo y consciencia de provocar un resultado que se sabe es ilegítimo ....................

5.3. Hacia un modelo del daño intencional . . . . . . . . . . . .

5.4. Tratamiento jurídico del daño intencional $\ldots \ldots \ldots \ldots . \quad 57$

5.5. El daño punitivo frente al error intencional ......... 61

5.6. Procedibilidad de la acción .................. 63

5.7. Causales de exoneración en el daño intencional ........ 65

5.8. Cómo medir eficientemente el daño punitivo ......... 69

5.9. De los posibles correctivos a la incertidumbre ....... 76

5.9.1. La aplicación de un múltiplo punitivo, capaz de medir la improbabilidad en la aplicación de la norma . 
5.9.2. La fijación del estándar de responsabilidad en el punto intermedio entre el coste marginal y utilidad .

5.9.3. Corrigiendo la incertidumbre a través de mecanis-

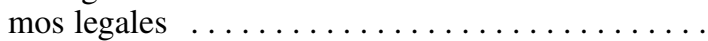

6. Eficiencia económica de las reglas de responsabilidad conven-

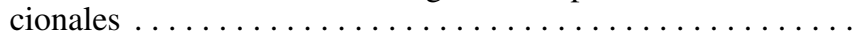

7. Conclusiones: futuro de la convención y propuestas de reforma

\section{Introducción}

Diversos son los intereses que la comunidad internacional ha debido conciliar durante las más de ocho décadas de regulación uniforme del transporte internacional aéreo. La complejidad legislativa se acentúa ante factores tales como el heterogéneo desarrollo económico entre los Estados negociadores, la especial naturaleza del mercado y la necesidad pública de delimitar reglas de competencia que incentiven la liberalización comercial, los retos tecnológicos implícitos en la industria aeronáutica, su alta siniestralidad, la indefensión del pasajero durante la ejecución del contrato y la correspondiente necesidad de cobertura de los riesgos aeronáuticos, el surgimiento y consolidación de bloques regionales de Estados, con intereses y competencias propias, la creciente preponderancia de organizaciones multilaterales de índole supraestatal o sectorial, etc.

Paralelo a los intereses descritos se encuentra la interdependencia de la industria aérea con las dinámicas globalizadoras, que a su vez imponen la necesidad de una uniformidad normativa que garantice la protección de los usuarios, con independencia de criterios territoriales propios del Derecho Internacional Privado. A pesar de los logros obtenidos, se revelan claros los retrocesos históricos de origen estatal, supraestatal y sectorial, importantes a la hora de valorar las perspectivas de éxito de la actual normativa convencional.

Las reglas de responsabilidad por muerte y lesiones a los pasajeros, objeto del presente estudio, constituyen el epicentro de lo que la doctrina ha denominado como «cisma» del sistema responsabilidad del Sistema de Varsovia (en adelante, SV 1929), vigente hasta el año de 1999, fecha de celebración del actualmente imperante Convenio de Montreal (en adelante, CM 1999).

La primera parte del trabajo se destinará al análisis del fenómeno aeronáutico; su especial connotación internacional; los distintos intereses en juego que han dificultado (y aún lo hacen) la tarea de uniformidad de los diversos instrumentos normativos vinculantes, sus alcances jurídicos según el origen convencional, supraestatal, sectorial o interno de la regulación; la evolución, retos y retrocesos del proceso codificador, los fenómenos de regionalización y autorregulación regulatoria; la posibilidad de escape de la Convención, las distorsiones resultantes del denominado forum shopping, la 
eventual aplicación de normas de conflicto propias del Derecho Internacional Privado, y el alcance de las soluciones jurídicas legeforistas.

Posteriormente, se intentará valorar la eficiencia económica de las distintas reglas y regímenes de responsabilidad, de origen convencional, actualmente vigente (CM 1999) para los supuestos de muerte y lesiones personales de pasajeros. Lo anterior, dentro de un contexto de mercado que demandará una previa delimitación del objeto de estudio del análisis económico del Derecho, su relación con otras disciplinas cognoscitivas y sus falencias metodológicas.

Es necesario resaltar la mayor preponderancia de algunos Estados, no solo en la configuración del sistema convencional, sino como garantes de su éxito. Debe anticiparse que Estados tales como EE. UU., Japón, Reino Unido, y los pertenecientes a la Comunidad Europea (es decir, los más poderosos) provocaron la ruptura del octogenario Sistema de Varsovia, debido en parte a la inflexibilidad de dicho instrumento para adaptarse a nuevas coyunturas sociales, políticas y económicas; pero, principalmente, debido a la divergencia jurídica y axiológica entre los países del Common Law y los del Derecho Continental (o civilistas). Tales divergencias se clarifican mejor con la ayuda del método económico, que intentaremos emplear para demostrar que, muy a pesar de los loables avances del actual CM 1999, sus pronósticos de éxito son reservados, al menos desde esta perspectiva.

Finalmente, debe adelantarse que la imperatividad del CM 1999 relativa a los límites resarcitorios no excluye que, acreditando la víctima elementos de imputación subjetiva contra el transportista-agente, puedan reconocerse rubros mayores. Se buscará resolver la disyuntiva acerca de si los regímenes de responsabilidad convencionales son indemnizatorios o si, por el contrario, viabilizan la materialización de políticas públicas de prevención que suelen emplear los cauces civiles para tal efecto, en referencia concreta al daño punitivo (daño intencional). No obstante, y con independencia de la respuesta que se dé a tal interrogante, resulta conveniente que, al menos en un plano meramente académico, se definan las posibles acepciones del concepto «daños punitivos», para así compatibilizar su aplicación con el principio de reparación integral del daño, común a los sistemas del Common Law y de Derecho Continental.

\section{Del carácter internacional del transporte aéreo}

La caracterización del transporte aéreo como internacional exige, en primera medida, entender su importancia dentro del fenómeno de la globalización ${ }^{1}$. Desde esta perspectiva, y apelando a criterios comerciales, todo trans-

${ }^{1}$ La recíproca incidencia que la globalización ejerce sobre en el transporte aéreo merece un doble enfoque. Por una parte, incentiva el desarrollo tecnológico de la industria aeronáutica, al tiempo que favorece prácticas corporativas basadas en economías masivas (de 
porte aéreo tiene algún elemento internacionalizador ${ }^{2}$. A similar presunción se llega desde un enfoque meramente jurídico ${ }^{3}$, habida cuenta de la complejidad de la industria aeronáutica, en la cual confluyen relaciones y criterios de diversa índole: espaciales, territoriales, materiales, subjetivos y objetivos ${ }^{4}$.

La complejidad subyacente a las relaciones jurídicas que estructuran el transporte aéreo internacional sugirió, desde la génesis misma de la aviación, un tratamiento legislativo no solo «supranacional», sino también independiente de las respuestas iusprivatistas clásicas ${ }^{5}$. El Derecho Aeronáutico Internacional encontró en organizaciones internacionales ${ }^{6}$, de origen estatal (Organización de la Aviación Comercial Internacional, OACI) y sectorial (Asociación del Transporte Aéreo Internacional, IATA), espacios de negocia-

escala, de gama, etc.), sinergias, políticas de cooperación (la cual va desde el simple outsourcing hasta el joint venture); lo que repercute en un incremento de la eficiencia, y por ende, del beneficio que reporta finalmente el pasajero. Un segundo enfoque se relaciona con la positivización normativa de dichas nuevas realidades por parte del Derecho Convencional; ejemplo de ello es la extensión del modelo de responsabilidad del transportista contractual, contenido en el SV, al de hecho, verificada a través del la Convención de Guadalajara de 1961; y la valoración de las escalas como criterio utilizado para delimitar el ámbito de aplicación de la norma internacional, entre otras.

${ }^{2} \mathrm{El}$ «mercado», como ámbito de interconexión de procesos productivos, presupone que todo bien o servicio está pensado para satisfacer intereses, con independencia de límites espaciales, personales o temporales.

${ }^{3}$ De PAZ Martín, Jesús. La responsabilidad en el transporte aéreo internacional: de Varsovia (1929) a Montreal (1999). Universidad de Castilla-La Mancha. Madrid: Ed. Marcial Pons, 2006, p. 33: «Si se manejara la presunción amplia consistente en la atribución, en sentido contrario, del carácter interno a todas aquellas relaciones jurídicas que carezcan de cualquier elemento de internacionalidad, podría concluirse que en el transporte aéreo la práctica totalidad de las relaciones que se derivan de él son internacionales».

${ }^{4}$ Innumerables son las relaciones jurídicas que configuran el transporte aéreo, entre las que pueden ejemplificarse las relativas a la fabricación de la aeronave, las de índole laboral respecto del personal aeroportuario, las de naturaleza contractual privatista (origen de las partes, modalidades de contratación, lugares de ejecución del transporte, etc.) y pública (licencias de funcionamiento, de control y tráfico aéreo, de seguridad pública, etc.), y demás que configuran de plano obligaciones extracontractuales como en relación con los terceros de superficie.

${ }^{5}$ Entiéndanse, por una parte, las clásicas reglas de conflicto recogidas en el Derecho Internacional Privado para determinar la ley aplicable y la jurisdicción competente en relaciones jurídicas no internas (es decir, con algún elemento internacional); así como el abandono del modelo iusprivatista liberal, por una regulación pública de mercados. Sin reparar en matices propios de la transición vivida por cada Estado, lo cierto es que debido a los intereses en juego (económicos, políticos, de seguridad pública, etc.), la consolidación de la industria aeronáutica como fenómeno internacional coincidió, al menos temporalmente, con el surgimiento del modelo político del Estado interventor (si bien tal modelo se consolidaría posteriormente -sobre todo en Europa- con posterioridad al período de guerras).

${ }^{6}$ Entre los espacios de estudio y negociación regional destacan la Comisión Europea de la Aviación Civil (CEAC) y el Instituto Iberoamericano de Derecho Aeronáutico y del Espacio y de la Aviación Comercial (INIDAE). 
ción que incentivaron su desarrollo. El diseño de un instrumento regulatorio material y uniforme ${ }^{7}$-reglas y su interpretación-, indiferente de fronteras físicas o ideológicas, se estimó necesario para imprimir estabilidad a una industria naciente con alto contenido político ${ }^{8}$.

Más allá de la valoración que pueda efectuarse del contenido material de los distintos convenios y protocolos, conviene resaltar la siempre presente consciencia de la comunidad internacional relativa a la importancia de conciliar los más variados y contradictorios intereses ${ }^{9}$ en un único texto regulador $^{10}$. Dichos intereses se refieren, principalmente, a los Estados, individualmente considerados, o en bloque regional (soberanía); a las aerolíneas (viabilidad económica de la industria, limitación de responsabilidad, consideración de riesgos exógenos y endógenos específicos del servicio, etc.); a los usuarios, a los terceros en superficie (mayores garantías); así como al propio mercado (mayor liberalización, reglas más claras de competencia, incidencia de los actores privados -autorregulación-, etc.).

Los esfuerzos conciliatorios de los más variados actores de la relación aeronáutica se materializaron en múltiples protocolos modificatorios del Convenio de Varsovia de 1929 (en adelante, CV 1929), los cuales conformaron un sistema imperativo durante siete décadas. Sin demeritar los logros obtenidos en tales normativas (en cuya negociación, no sobra decirlo, con-

${ }^{7}$ «El Convenio Internacional no es la única solución a la necesidad de internacionalidad y uniformidad del Derecho Aeronáutico... ; hay otros, tales como la autorregulación en el seno de organizaciones gremiales, la adopción unilateral y voluntaria por parte de los Estados de reglamentaciones con cierto grado de uniformidad, y el cumplimento de los compromisos adquiridos en virtud de normas convencionales de carácter programático»; por ejemplo, los Anexos de la OACI elaborados en virtud del Mandato del Art. 37 del Convenio de Chicago de 1944 (DE PAZ Martín, Jesús, ob. cit., p. 69).

${ }^{8}$ La industria aeronáutica se erigió en estandarte de las economías nacionales, fomentando el inicial proteccionismo, y condicionando el desarrollo del Derecho convencional.

${ }^{9}$ Veremos en profundidad cómo la configuración de los regímenes convencionales de responsabilidad, en especial para los supuestos de muerte y lesiones de pasajeros, buscan equilibrar los intereses de estos, de las compañías transportistas, así como de los que eventualmente pudieran derivar daños en superficie; intereses a su vez condicionados por factores sui generis del transporte aéreo, principalmente los relativos a la actividad misma (siniestralidad entendida como el alto coste de los accidentes), a las partes del contrato (nivel de diligencia y retos tecnológicos), y al contexto de regulación pública en el cual se inserta (control del tráfico aéreo y medidas de seguridad).

${ }^{10}$ La uniformidad del Derecho Aeronáutico se orientó a tres sectores concretos: el público-organizativo, el privado y el penal. «Centrándonos en la regulación de las relaciones jurídico-privadas nacidas en el ámbito de la actividad aeronáutica, la clásica función del Derecho Internacional Privado, es decir, la localización y determinación del ordenamiento jurídico estatal aplicable a las relaciones de tráfico jurídico externo o situaciones privadas internacionales, se reorientó, desde los orígenes del Derecho Aeronáutico Internacional Privado, precisamente hacia la evicción de dicha función localizadora» (DE PAZ MARTín, Jesús, ob. cit., p. 68). 
fluyeron Estados jurídica y económicamente dispares), lo cierto es que su solapamiento, paralelo a los fenómenos de regionalización ${ }^{11}$ y autorregulación, terminaron por ahondar la fisuras del sistema convencional (Sistema de Varsovia), propiciando soluciones diferentes a una misma realidad, y por ende, atentando contra la tan anhelada seguridad jurídica del modelo uniformador.

Los mayores retrocesos experimentados durante la «vigencia» del Sistema de Varsovia (en adelante, SM) giran alrededor de las reglas de responsabilidad del transportista, principalmente los supuestos de muerte y lesiones personales de pasajeros, objeto del presente estudio. Esto obedece a la inflexibilidad del SM para adaptarse a nuevas realidades, concretamente la creciente consolidación financiera de las compañías aéreas licenciadas en Estados con economías fuertes y con tecnologías mejor desarrolladas.

Resulta interesante apreciar como una misma realidad fáctica (la aviación) es susceptible de las más disímiles interpretaciones. Ejemplo de ello es la denuncia estadounidense de la primera gran reforma del CV 1929 (Protocolo de la Haya de 1955; en adelante, PH 1955). La multiplicidad de reformas posteriores, ratificadas por un número desigual de Estados, aunado al impulso que ciertos Estados (y el propio gremio, de manera no siempre espontánea), tales como EE. UU., Reino Unido, Japón, y los miembros de la UE, dieron a la autorregulación, desembocaron en el fenómeno de la «especulación procesal» (forum shopping), aún existente, aunque con dinámicas distintas.

No obstante, sería injusto ignorar la importancia que el Derecho uniforme de origen convencional ${ }^{12}$, relativo al régimen de responsabilidad civil de las compañías aéreas, tiene para la materialización de políticas de liberalización del sector ${ }^{13}$. En sentido contrario, tales políticas liberalizadoras del sec-

${ }^{11} \mathrm{Si}$ bien la regionalización influyó en la ruptura del sistema convencional, tras la ratificación del Convenio de Montreal es plausible su función extensiva, al acuñar el concepto de «compañía comunitaria» como criterio subjetivo de aplicación de los respectivos reglamentos; los cuales, a su vez, reconocen la supremacía del instrumento internacional (CM 1999). Sobre este punto se volverá más adelante, cuando expliquemos los fenómenos de uniformidad y coherencia del Derecho convencional, como contrapuestos al de ruptura. Acerca de la compleja relación entre ambos sistemas y el eventual «solapamiento de normas», ver DE PAZ MARTín, Jesús, ob. cit., p. 54: «La regularización comunitaria también tiene efectos ad extra en cuanto a que su contenido se solapa con el contenido de las normas convencionales de las cuales son partícipes -por su ratificación- los Estados miembros que integran la CE. Esto ha provocado una especial situación jurídica».

${ }^{12}$ Podría considerarse más acertado hablar de uniformidad y no de unificación, ya que este último término implica un grado de unión jurídica difícilmente accesible en el marco jurídico internacional. Esto es así puesto que, a falta de una organización judicial internacional que unifique la interpretación de las normas que lo integran, por muchos esfuerzos normativos que se empleen a nivel internacional, siempre aparece el problema de su interpretación localista.

${ }^{13}$ Proyecto de Declaración de principios universales para el transporte aéreo internacional, Conferencia Mundial de Transporte Aéreo: Retos y oportunidades de la liberalización (OACI), Montreal, 24-29 de mayo de 2003, ATConf/5-WP/19, 6/3/03. 
tor aéreo han cumplido una notoria función promotora del Derecho unifor$\mathrm{me}^{14}$.

Con la llegada del CM de 1999, se superan muchas de las inconsistencias del anterior sistema. Su mayor logro fue el haber superado la nefasta identificación de los conceptos «uniformidad» y «universalidad»; al dar un mejor enfoque a las soluciones legeforistas, en claro reconocimiento de la connotación internacionalidad- Derecho uniforme del transporte aéreo, sin desmedro de los particularismos de los operadores jurídicos (Tribunales del foro) insertos en sistemas jurídicos disímiles.

\section{Reseña histórica: del Sistema de Varsovia al Convenio de Montreal de 1999}

El método histórico resulta fundamental a la hora de valorar las perspectivas de éxito del actualmente vigente CM 1999, no solo porque este recoge modificaciones ya introducidas en el anterior SV, tanto por vía de la regulación regional como por la autorregulación, sino también porque es posible apreciar la permanencia de las causas que dieron lugar a las distintas modificaciones del original CV 1929. Es más, tal método sirve para coadyuvar el análisis económico que de las normas de responsabilidad se efectuará en la segunda parte de este escrito, a través del cual se intentará demostrar la ineficiencia tanto del modelo previo como del actual; si bien resultará claro para el intérprete que otros criterios (en especial el político y el sociológico) han podido ser más determinantes en su evolución.

El origen del Derecho Internacional Aéreo puede remontarse a las Conferencias de París de 1925 (en las que se creó la Comisión Internacional de la Navegación Aérea, CINA), como preámbulo del CV $1929^{15}$ (que a su vez

${ }^{14}$ Entre los distintos reglamentos que explican la promoción que del Derecho cconvencional ha efectuado el Derecho comunitario, pueden mencionarse los R. 2407/92/CE (sobre la concesión de licencias a los transportistas aéreos), R. 2408/92/CE (sobre el acceso de los porteadores aéreos de las rutas intracomunitarias), R. 2409/92/CE (sobre las tarifas aéreas para el transporte de pasajeros y mercancías), R. 2027/97/CE (sobre protección de intereses patrimoniales de los usuarios), R. 2410/92/CE y 2411/92/CE (modificatorios de los R. 2975/87 y R. 3976/87), R. 2320/2002/CE (sobre normas comunes para la seguridad de la aviación civil), y el R. 847/2004/CE (sobre la «dimensión exterior», o negociación y aplicación de acuerdos de servicios de trasporte aéreo entre Estados miembros y terceros países). Una mejor descripción de la influencia recíproca entre ambos sistemas jurídicos (el comunitario y el convencional) en Calvo Caravaca y Carrascosa González. Desregularización del sector aéreo y Derecho comunitario, CDP, N. ${ }^{\circ} 4,1998$, pp. 9 y ss.

${ }^{15}$ Otros trabajos preparatorios del CV 1929 se llevaron a cabo en las Conferencias de Bruselas (1927) y Madrid (1928). Un recuento histórico conciso puede encontrarse en DIEDERIKS-VERSCHOOR. An Introduction to Air Law. Ámsterdam: Ed. Kluwer Law International, 8. ${ }^{\mathrm{a}}$ ed., 2006, pp. 2-6. 
dio origen al Comité Internacional Técnico de Expertos Jurídicos Aéreos, CITEJA).

Tal y como se ha anticipado, el CV 1929 responde fundamentalmente a la consciencia internacional ${ }^{16}$ de uniformidad de una actividad considerada desde entonces pilar de desarrollo y unión de las naciones; así como de protección de una industria incipiente, caracterizada por la incertidumbre tecnológica y los altos riesgos derivados de la siniestralidad. Su masiva aceptación, tanto por parte de Estados, muchos de los cuales extendieron directa e indirectamente las soluciones convencionales a sus respectivas ordenamientos internos; como de las compañías aéreas, le auguró éxito al Convenio.

El desarrollo tecnológico, la consolidación financiera de la industria, así como un mayor sentido de protección a los usuarios, tornaron nugatorias las reglas convencionales, en especial las referidas a los distintos regímenes de responsabilidad del transportista. En efecto, el modelo de culpa presunta y los bajos límites indemnizatorios en supuestos de muerte y lesiones personales de pasajeros, contenido en el CV 1929, y que será objeto de un posterior análisis, provocaron su revisión; bajo la apremiante necesidad de mantener la vigencia del instrumento internacional en Estados que, como EE. UU., marcaban inexorablemente el derrotero de la uniformidad.

La primera reforma, surtida a través del Protocolo de la Haya de 1955, fue sentenciada a muerte por la denuncia que de ella hizo EE. UU.; mayor propulsor de la autorregulación, técnica cuya trascendencia quedó demostrada en el Acuerdo de Montreal de 1966 (acordado en el seno de la IATA; en adelante, AM 1966). Como era apenas previsible, en dicho acuerdo se consagró un modelo de responsabilidad objetiva, dentro de unos límites resarcitorios significativamente más elevados. A pesar de su limitado ámbito de aplicación (aerolíneas que operaban desde o hacia EE. UU.), el AM 1966 influyó notoriamente, no solo en posteriores reformas convencionales, regionales y gremiales, sino también en la necesidad de flexibilizar el sistema.

Un año antes de celebrar el AM 1966, EE. UU. retira la denuncia del CV 1929, como muestra de su interés por auspiciar una nueva negociación internacional, esta vez en el seno de la OACI. Esto desencadena la negociación del Protocolo de Guatemala de 1971 (en adelante, PG 1971), el cual, pese a no entrar en vigor debido a su insuficiente ratificación estatal, consagró importantes reformas al SV, entre las que destacan el incremento sustancial del límite indemnizatorio (en relación con pasajeros y sus equipajes), su revisión periódica y automática, una nueva clasificación de conductas dañinas

${ }^{16}$ Concretamente, consciencia «de necesitar un régimen armonizado en el transporte aéreo internacional (especialmente, en lo relativo al régimen de responsabilidad); el esfuerzo de los Estados por alcanzar un instrumento lo más universal posible; y, estrechamente ligado a lo anterior, la superación de las particularidades jurídicas nacionales a favor de la generalización del instrumento normativo surgido». DE PAZ MARTín, Jesús, ob. cit., p. 72. 
(v.gr., el retraso), un modelo de responsabilidad objetiva en el transporte de personas, así como un sistema indemnizatorio complementario basado en la concertación de un seguro ${ }^{17}$.

La ruptura del sistema varsoviano se evidencia en el tres fenómenos concomitantes (el primero de los cuales recibirá un mejor análisis posterior): el desconocimiento (si bien excepcional) de los límites convencionales por parte de los tribunales norteamericanos (algunas de las sentencias fueron revocadas en apelación), los que, apelando a la connotación «niveladora» del daño punitivo, y en supuestos de dolo o culpa cualificada (daño intencional), terminaron por aplicar reglas (si bien de manera soterrada) forales del régimen común (Common Law); el desarrollo de la normativa comunitaria resultante de la materialización de políticas integracionistas y liberalizadoras; y la consolidación de la autorregulación, la mayoría de las veces producto de dinámicas intrínsecas del mercado relativas a un reforzamiento de las garantías como mecanismos de competencia, así como de diversas operaciones concentracionistas (especialmente en Europa y EE. UU.).

En cuanto a la regulación comunitaria del transporte aéreo internacional, puede afirmarse, sin temor a equívocos, que se erige como respuesta a la grave crisis del Sistema de Varsovia ${ }^{18}$; no solo en relación con los límites indemnizatorios del transportista por muerte o lesiones personales de pasajeros, sino también respecto de otros problemas específicos no regulados por el texto internacional ${ }^{19}$. No obstante, debe admitirse la existencia de dinámicas propias del proceso comunitario ${ }^{20}$ (en especial, la consolidación de las liber-

${ }^{17}$ De Paz Martín, Jesús, ob. cit., p. 75.

${ }^{18}$ Respecto de la responsabilidad del transportista por muerte y lesiones personales de pasajeros, el Derecho comunitario abandonó completamente el régimen convencional con el R. 2027/97/CE (reemplazado por el actualmente vigente R. 889/2002/CE); modificando los límites indemnizatorios. Tal abandono no fue casual ni mucho menos original. Los límites contenidos en el SV ya habían sido desconocidos (aunque parcialmente) en distintos acuerdos privados suscritos entre compañías aéreas, o entre estas y Estados miembros. En la Propuesta de Decisión del Consejo sobre la aprobación por la Unión Europea del CM 1999, 446 final, de 14 de julio de 2000 (citado por De PAZ MARTín, Jesús, ob. cit., p. 89), se ponía de manifiesto la necesidad de reforma, en estos términos: «(...) Para los cánones actuales, estos límites -a la responsabilidad por daños en caso de lesión y muerte de pasajeros y de pérdida de equipaje- resultan muy bajos e incluso los establecidos en los diversos acuerdos modificatorios que componen el denominado Sistema de Varsovia ofrecen una compensación muy poco adecuadas a las víctimas de accidentes y a sus derechohabientes».

${ }_{19}$ Ejemplo de esto es el R. 295/91/CE, por el cual se establecen normas comunes relativas a un sistema de compensación por denegación de embarque en el transporte aéreo regular (reglamento, a su vez, modificado y reemplazado por el R. 261/2004/CE, el cual adaptaba las soluciones dadas por el CM 1999).

${ }^{20}$ AREAL LudEÑA, Santiago, ob. cit., p. 766: «Su importancia -la del R. 2027/92- ... radica en que no solo introduce, como veremos... una importante batería de interesantes novedades legislativas, sino que, además, unifica, en el espacio aéreo comunitario, las normas aplicables a la responsabilidad de las compañías aéreas, eliminando la distinción entre 
tades europeas), que impusieron la necesidad de encontrar mecanismos jurídicos que homogeneizaran las normativas nacionales, muy dispares entre $\mathrm{Si}^{21}$.

La fractura del SV se hizo palpable en el ámbito comunitario con el R. 2027/97/CE, el cual no solo elevaba los límites de responsabilidad, de manera aparentemente ilegal ${ }^{22}$, sino que obligaba al pago de indemnizaciones anticipadas en caso de lesión o muerte de pasajeros.

Debe ahora explicarse la influencia recíproca que ejercen la regulación convencional y la comunitaria. Por una parte, las innovaciones comunitarias fueron directa e indirectamente recogidas por el CM 199923; al tiempo que la comunidad adaptó su normativa al Convenio, condicionando su eficacia a la de aquel ${ }^{24}$. Como corolario de lo anterior, puede sostenerse que, además de su intrínseca función unificadora ${ }^{25}$, la regionalización ha servido al Derecho convencional como canalizador e inductor de las reformas reseñadas,

accidentes domésticos y no domésticos y, de este modo, contribuyendo a la creación de un nuevo concepto: el cielo único».

${ }^{21}$ En efecto, la multiplicidad de textos reformatorios del CV 1929, no todos ratificados por algunos Estados miembros, provocó el solapamiento de normas que imposibilitaban la consolidación del Mercado Común. En este sentido, debe resaltarse el hecho de que la política Europea de Mercado Común, en procura de la mayor libertad contractual, limita la intervención pública al mero equilibrio entre derecho de los pasajeros y los intereses gremiales; situación que, evidentemente, ha estimulado la autorregulación, sobre todo en aquellos aspectos no previstos por el Derecho. Lo anterior para concluir que el abandono comunitario del SV no puede ser totalmente imputado a falencias intrínsecas del sistema convencional, más que a los factores reseñados.

${ }^{22}$ El SV permitía que, a través de la autorregulación, las compañías aéreas aumentasen los límites de responsabilidad convencionales, a través acuerdos entre ellas, respecto de Estados o grupos de Estados, bien en el seno de organizaciones multilaterales; sin embargo, la facultad no se hacía extensiva a los Estados.

${ }^{23}$ Concretamente, la facultad que el CM 1999 reconoce a los Estados signatarios para consagrar (y regular) el pago anticipado obligatorio de montos pecuniarios predefinidos (aunque bajo el límite material de que dicho anticipo no implica un reconocimiento tácito de la responsabilidad del transportista); así como incrementar los límites de responsabilidad.

${ }^{24}$ Con la finalidad de alcanzar una mayor uniformidad, la UE conminó a los Estados miembros (en adelante, EM) a que ratificasen conjuntamente el CM 1999. Sin embargo, y en consideración a que algunos EM no lo hicieron, resulta claro que el SV continúa vigente en aquellos asuntos no regulados expresamente por la normativa comunitaria; y hasta que CM 1999 no equipare en extensión geográfica la ratificación que en su momento alcanzó el CV 1929. Esto lleva a DE PAZ MARTín, Jesús, ob. cit., p. 89, a rechazar la técnica rupturista; la cual sugiere la denuncia previa de los distintos instrumentos integrados en el SV, como requisito para ratificar el CM 1999.

${ }^{25}$ Principalmente, en su función de unificar la interpretación de las distintas soluciones materiales, no solo respecto de la normativa comunitaria, sino también, y por extensión, de la convencional, a través del Tribunal de Justicia de la Comunidad Europea. 
complementando su contenido material ${ }^{26}$; suplantando su imperatividad ${ }^{27}$, e incluso extendiendo su aplicación a transportes no definidos como internacionales según las normas dadas por el propio CM $1999^{28}$.

Por su parte, el papel que la autorregulación ha desempeñado en la configuración del Derecho convencional ha sido de tal trascendencia, que muchos autores han hablado de una «nueva lex mercatoria aeronáutica» ${ }^{29}$. Como se ha anticipado, la autorregulación ha sido auspiciada por algunos Estados que, como EE. UU., han desconocido, explícita o implícitamente, la imperatividad del Derecho convencional; sobre todo en lo relativo a los regímenes de responsabilidad del transportista en los supuestos de estudio.

En efecto, aunque el fenómeno de la autorregulación pueda ser entendido en el marco de la competencia empresarial, como quiera que el mayor reconocimiento de garantías y derechos de los pasajeros, como política comercial repercute positivamente en un mejor posicionamiento de la compañía aérea en el público referenciado; resulta indiscutible su definición como causa-efecto del vacío normativo característico de la ruptura del SV. El modelo plasmado en AM de $1966^{30}$, fue incorporado al unísono por las aerolíneas en las condiciones generales de contratación ${ }^{31}$, provocando lo que la doctrina describe como «bicefalia normativa $»^{32}$.

${ }^{26}$ En asuntos no regulados por el CM 1999, tales como, por ejemplo, los «grandes retrasos»; y la obligación de contratar seguros de responsabilidad, referenciados en los límites convencionales de responsabilidad, como requisito para la concesión de licencias de explotación.

${ }^{27}$ En lo relativo a la denegación de embarque y cancelación de vuelos, cuando no sea aplicable el CM 1999.

${ }^{28}$ La extensión es tanto material (como en su momento lo hizo el R. 2027/97/CE, en relación con las reglas de responsabilidad en los supuestos de retraso y pérdida de equipajes), como espacial (a través del concepto de «compañía comunitaria», en el entendido de que el Régimen comunitario, y por asimilación el convencional, se aplica a los transportistas que operen bajo licencias de explotación concedidas por alguno de los EM, con independencia de criterios territoriales, tales como el lugar de salida y destino del vuelo; lo cual implicaba que su imperatividad podía alcanzar modalidades de transporte interno). La extensión es tal, que el propio R. 889/2002/CE obliga a que los EM, individualmente, extiendan la aplicación del CM de 1999 a aquellos supuestos no cubiertos por él, ni por la normativa comunitaria.

${ }^{29}$ De Paz Martín, Jesús, ob. cit., p. 82.

${ }^{30}$ Otras acuerdos autorreguladores son, principalmente, el Acuerdo de Malta de 1975 (entre empresas europeas y en el que se eleva el límite indemnizatorios a 100.000 DEG); la denomina «iniciativa japonesa» de 1999 (renuncia de los límites de Varsovia y de las defensas del art. 20 CV hasta los 100.000 DEG); el Acuerdo de Kuala Lumpur de 1995 (adecuación del límite indemnizatorio a la recomendación ECAC/16-1); y el Acuerdo de Miami (renuncia al límite de responsabilidad en materia de pasajeros y a la acción de defensa del art. $20 \mathrm{CV}$ hasta los 100.000 DEG; norma seguida por CM [1999])» (Paz, 85).

31 «Aunque la autorregulación se ha erigido como un elemento distorsionador del proceso de unificación estatal, no ha dejado de suponer un elemento unificador» (Paz, 83).

${ }^{32}$ Areal LudeÑA, Santiago. «El Contrato Internacional de Transporte Aéreo», en Curso de Contratación Internacional (A. L. CAlvo CARAvaca y J. CARRascosa González -dirs.-). Madrid: Colex, 2003, p. 765. 
La importancia de organismos internacionales de naturaleza sectorial, como por ejemplo la IATA ${ }^{33}$ (International Air Transport Association), es indiscutible; no solo porque en su seno se auspiciaron distintos acuerdos entre las compañías transportadoras, sino también por su amplia competencia regulatoria. Esta competencia fue indirectamente reforzada por la normativa convencional, desde el CV 1929 hasta el CM $1999^{34}$, en que se reconoce validez a la autorregulación que no la contraríe.; "plus adicional de validez» frente a la posibilidad de que los Estados declaren su nulidad en aplicación de las normas imperativas forales (esto debe matizarse en el entendido de que los principios y demás normas de orden público forales solo ceden -en principio, debiéndose valorar cada caso concreto-, ante la imperatividad directa del Convenio).

La lógica tensión entre regulación y autorregulación puede resumirse del siguiente modo: 1. La intervención pública del transporte aéreo es «de mínimos», o sea, limitada a lo esencial para preservar el equilibrio de las partes, así como de los intereses legítimos de otros actores extracontractuales implicados. 2. La influencia recíproca entre las mencionadas técnicas legislativas produce efectos ex ante (en sede normativa), y ex post (posibilidad de aumentar contractualmente los límites indemnizatorios; eliminar cláusulas exonerantes preestablecidas, etc.). 3. La autorregulación es pilar fundamental de la competencia, además de coadyuvar el mejoramiento natural y sostenible en las condiciones de seguridad. 4. La autorregulación sirve para reforzar políticas públicas, por ejemplo, condicionando la concesión de licencias de explotación a la suscripción, por parte de los interesados, de acuerdos que desarrollen normativas marco de los Estados, individualmente considerados o en bloque (ejemplo de ello son los denominados «códigos de conducta interempresariales» auspiciados por la UE) ${ }^{35}$.

A manera de conclusión, la autorregulación ha incidido en la configuración del sistema como motor de impulso de los cambios, en relación sobre todo con los límites de responsabilidad, las causales de exoneración, las condiciones de validez de las cláusulas de no responsabilidad y su adecuación a la norma convencional, etc.

${ }^{33}$ La IATA nace en 1945 en la Conferencia de la Habana y reemplaza a la International Air Traffic Association (antigua IATA), creada a su vez en La Haya en 1919. Es una organización que agrupa a las empresas de transporte aéreo de personas o mercancías que prestan servicios regulares. Actualmente, aglutina empresas que representan el $94 \%$ del transporte aéreo mundial. Sus resoluciones no son vinculantes, aunque sí mayoritariamente seguidas. Ver DIEDERIKS-VERSCHOOR, ob.cit, pp. 10 y 11.

${ }^{34}$ CM 1999, art. 27: «Ninguna de las disposiciones del presente convenio impedirá al transportista negarse a concertar un contrato de transporte, renunciar a las defensas que puede invocar en virtud del presente convenio, o establecer condiciones que no estén en contradicción con las disposiciones del presente convenio».

${ }^{35}$ Sobre la influencia recíproca entre regulación y autorregulación, ver DE PAZ MARTín, Jesús, ob. cit., pp. 81 y ss. 
En consecuencia, conviene sintetizar las principales causas, tanto intrínsecas como extrínsecas, que suscitaron la crisis y posterior ruptura del CV 192936:

1. Inadecuados criterios de política legislativa en la valoración de soluciones jurídicas forales, regionales y autorreguladas (adaptativas, extensivas e interpretativas).

2. Su inflexibilidad para adecuarse a nuevas realidades, económicas y políticas. En efecto, el original CV 1929 no contemplaba (como sí lo hace el CM 1999) mecanismos de revisión periódica de los límites indemnizatorios; además de su poca claridad conceptual.

3. Disparidad en la ratificación de los distintos instrumentos que configuran el SV. Como consecuencia de ello, algunos Estados optaron por la incorporación material de los principios y reglas convencionales a su normativa interna, pero ajustándolos a sus propios criterios.

4. Divergencia interpretativa entre los Estados parte del SV. Esto se debe, principalmente, a la poca claridad de las reglas convencionales, así como a la ausencia de un operador judicial internacional.

5. Ausencia de versiones oficiales del Convenio en otros idiomas distintos del francés.

6. Lagunas jurídicas (por ejemplo, en la definición de los plazos establecidos para el ejercicio de las acciones judiciales de reclamación).

7. Ausencia de uniformidad en los criterios de cuantificación de los montos resarcitorios (el sistema original preveía la conversión del franco-oro como patrón de referencia; modelo sustituido por el de Derecho Especial de Giro, en adelante, DEG).

8. La no adecuación de los límites indemnizatorios resultante, principalmente, del «sistema de compensación suplementaria» incorporado en el PG 1971.

9. La compartimentación o fragmentación derivada de las sucesivas modificaciones del texto original (la ratificación desigual de los diversos protocolos constituyó la principal amenaza ${ }^{37}$ ), la autorregulación y regionalización; fenómenos que hicieron más compleja su aplicación.

Finalmente, debe plantearse el interrogante relativo a si CM 1999 implica una ruptura definitiva del SV. La doctrina esgrime el carácter compilador (función unificadora) del CM 1999, para sostener que tal ruptura no es definitiva; todo lo contrario, puede considerarse como la culminación del dilata-

${ }^{36}$ De Paz Martín, Jesús, ob. cit., p. 71.

${ }^{37} \mathrm{Tal}$ disparidad obedece a las «desigualdades económicas interestatales entre el Norte y el Sur surgidas especialmente en el período de post-guerra, que, a su vez, provocaba la divergencia de los intereses económicos, políticos y jurídicos» (DE PAZ MARTín, Jesús, ob. cit., p. 78). 
do proceso de revisión del CV 1929. No obstante, las amenazas de un nuevo cisma del Derecho convencional siguen latentes, mucho más ahora que el mundo experimenta una reacomodación de poderes ante el ocaso de las potencias económicas del s. Xx y el surgimiento de Oriente y Sudamérica. No será extraña una eventual reivindicación de los intereses que dieron origen al CV 1929; en esencia, un mayor proteccionismo de la industria aeronáutica en detrimento de las garantías a usuarios, la mayor injerencia pública en el sector y, posiblemente, un abandono del modelo actual.

\section{3. Ámbito de aplicación y 'forum shopping'}

Forum shopping (también llamado bad forum shopping) es un concepto acuñado por la doctrina iusprivatista internacional para referirse a aquella técnica procesal a través de la cual conscientemente se somete una determinada realidad jurídica a jurisdicciones y/o normativas más favorables a las pretensiones accionadas. Lo que en principio no debería ser mal visto, adquiere una connotación negativa cuando se atenta contra la uniformidad perseguida por regulaciones uniformes; es decir, cuando el interés particular es valorado, de manera tecnicista, como preferente a la seguridad jurídica que inspira un modelo estable, predecible y armonizado.

El forum shopping es causa-efecto del cisma del Derecho Aéreo Internacional Privado ${ }^{38}$ como sistema autónomo y uniforme; desde el anterior SV, se proyecta como amenaza latente del actual CM 1999 y condiciona sus posibilidades de éxito.

Diversos y complejos son los factores que incentivan el forum shopping; entre los que pueden mencionarse los relativos al ámbito material de aplicación, a la estructura misma de la actividad, a la coexistencia de otras normativas, a las remisiones convencionales hacia soluciones legeforistas (tanto de reglas como de interpretación), a la ausencia consciente o inconsciente de regulación (mal denominadas como lagunas jurídicas) y, por supuesto, a la simple especulación suscitada por la presión ejercida por distintos grupos y colectivos $^{39}$. Debe aclararse que los factores relacionados con la remisión que el propio texto convencional realiza a lo largo de su articulado, en especial hacia la Lex Fori, y los vacios normativos, serán estudiados en detalle en el acápite siguiente.

38 «El orden terminológico obedece a la especificidad de la realidad jurídica aeronáutica y a las características de los instrumentos normativos que lo componen» (DE PAZ MARTín, Jesús, ob. cit., p. 35).

39 «Pensemos, por ejemplo, en el poder que tienen las asociaciones -americanas- de consumidores, tradicionalmente contrarias, por entender que la Normativa Convencional contienen unos límites indemnizatorios anormalmente bajos» (AREAL LudEÑA, Santiago, ob. cit., p. 760). 
Ahora bien, los criterios para delimitar el ámbito de aplicación del instrumento convencional en los supuestos de responsabilidad del transportista aéreo internacional, por muerte o lesiones personales de pasajeros, son territoriales y personales ${ }^{40}$. Así, el primer supuesto fáctico es el de vuelos con lugar de salida y destino en dos Estados parte del CM 1999 (art. 1.2). Debe mencionarse que, tratándose de compañías aéreas comunitarias ${ }^{41}$, el CM 1999 es imperativo, con independencia del criterio territorial, dado que el propio R. 2027/97 (y luego el R. 889/2002) lo hace extensivo ${ }^{42}$. El segundo supuesto es cuando el lugar de salida y destino estén en el territorio de un mismo Estado parte y se hubiese previsto una escala en otro Estado, con independencia de que este se hubiera adscrito o no al mencionado Convenio. En los demás supuestos, deberá atenerse el intérprete a la nacionalidad de la compañía y a los lugares de salida y destino del transporte, como foros generales de las reglas iusprivatistas de conflicto (ver acápite $\mathrm{V}, 3.2$ ).

\footnotetext{
${ }^{40}$ Junto con los criterios territoriales, en la delimitación de las reglas convencionales de responsabilidad aplicables al transporte aéreo internacional de personas, deberá atenderse a otros de carácter subjetivo (nacionalidad de las compañías aéreas), y materiales (debido a la regulación comunitaria expresa de algunos supuestos de responsabilidad regulados en el régimen convencional, como los «grandes retrasos», la muerte o lesiones personales de pasajeros); junto a la también regulación comunitaria de supuestos no regulados en el régimen convencional, como la denegación de embarque y las cancelaciones de vuelo (DE PAZ MARTín, Jesús, ob. cit., p. 290).

${ }^{41}$ Por compañía aérea comunitaria deberá entenderse «toda empresa de transporte aéreo que posea una licencia de explotación válida concedida por un EM de conformidad con el presente Reglamento»; en el cual se consagran como requisitos para el otorgamiento de tales licencias, el que las empresas a) tengan su principal centro de actividad o, en caso, su domicilio social en dicho Estado miembro y, b) su actividad principal sea el transporte aéreo, bien de forma exclusiva o bien en combinación con cualquier otra explotación comercial de aeronaves o de reparación y mantenimiento de aeronaves» (art. 4).

${ }^{42}$ En virtud de los arts. 1 y 3.1 del R. 889/2002, el CM 1999 se hace extensivo a todos los vuelos operados por compañías aéreas comunitarias, incluidos los «vuelos internos» (o «de cabotaje»). No sobra advertir que la normativa comunitaria será, en primer lugar, aplicable por los Estados miembros de la UE y, en segundo lugar, por aquellos Estados que, en virtud de normas de conflicto, apliquen la normativa de alguno de ellos. Es importante resaltar que la obligación que el R. 889/2002 impone a las compañías comunitarias de incorporar en los respectivos tiquetes resumen del régimen de responsabilidad convencional es apenas informativo y no puede fundamentar una reclamación de indemnización ni podrá ser utilizada como criterio interpretativo; lo que conlleva sostener que tal obligación informativa no implica una extensión del Convenio a terceros Estados (a través de las condiciones generales de contratación); a menos, claro está, que el Tribunal del foro les confiera fuerza vinculante (distinto a lo que establecía el R. 2027/97, en el que no se matizaba tal carácter meramente informativo, sino que se obligaba la publicidad de las condiciones de responsabilidad ilimitada y pago anticipado). Lo que tal información sí implica es la posibilidad de que el pasajero prefiera una compañía comunitaria sobre otra que no consigne similares garantías.
} 
La descripción anterior se debe a que, al ser el texto convencional, Derecho Material Uniforme (al igual que el anterior SV), resulta imperativo en los supuestos que regula; y no se admite solapamiento legítimo alguno. El forum shopping se da, en primera medida, por el desconocimiento del anterior principio. No obstante, es necesario analizar dos situaciones que podrían llegar a dificultar los criterios del art. 1, CM 1999, arriba descritos: el transporte sucesivo único, y el de hecho.

El primero de ello, no es otra cosa que la concurrencia de varios contratos para la ejecución final del traslado de pasajeros (o de mercancías); los que, no obstante, se tienen como uno solo, cuando las partes lo han considerado, expresa o tácitamente, «como una única operación». La regla convencional define que la responsabilidad no será solidaria, sino que recaerá en el transportista que haya efectuado el transporte durante el cual se hubiese producido el accidente; excepto que, por estipulación expresa, alguno de los trasportistas la hubiera asumido durante todo el viaje (art. 36.2, CM 1999).

Por su parte, el régimen convencional del transportista de hecho está contenido en los arts. 39 a 48 del CM 1999. De manera sucinta, puede explicarse que la responsabilidad de ambos transportistas (el contractual y el de hecho) será solidaria; pero matizada por la no extensión de una mayor responsabilidad del transportista contractual en virtud de una cualificación del elemento subjetivo de este respecto del transportista de hecho. Ahora bien, los límites indemnizatorios, en caso de muerte o lesión de pasajeros, se obvian cuando se pruebe culpa grave del transportista contractual, al tiempo que dicha cualificación de la culpa del transportista de hecho sí afecta al contractual (obviamente, lo afecta a él mismo).

Un segundo factor que incentiva el bad forum shopping se relaciona con la imperatividad misma del Derecho convencional; concretamente, el principio de Unidad de Culpa (el cual ha desencadenado flagrantes violaciones durante la vigencia del anterior SV, proyectables al actual CM 1999, en ordenamientos jurídicos de tipo continental); y la teoría de Jerarquía Normativa (auspiciada en Europa por dinámicas de regionalización jurídica; y en EE. UU. por un histórico imperialismo legislativo).

El análisis del principio de Unidad de $\mathrm{Culpa}^{43}$ debe empezarse por la afirmación de que la tradicional distinción entre responsabilidad contractual

43 «(...) Existen pronunciamientos judiciales españoles que siguen abriendo la posibilidad de que, en el ejercicio de esa libertad otorgada en virtud de la teoría jurisprudencial de la opción y al amparo del principio de unidad de culpa, el reclamante opte por una pretensión basada en la normativa específica contenida en el Derecho Convencional Uniforme o por una pretensión basada en la normativa general común (contractual o extracontractual)» (De Paz Martín, Jesús, ob. cit., p. 134). El autor cita la sentencia SAP de Barcelona de 11 de octubre de 2000, AC 2001/2, como ejemplo para demostrar como otros principios jurídicos han sido utilizados por la jurisprudencia española para fundamentar tal concurrencia de regímenes (el convencional y el interno), como el principio de reparación integral del 
y extracontractual (no obstante resultar insulsa para algún sector de la doctrina $^{44}$ ), debe valorarse en la relación jurídica del transporte aéreo internacional, fácilmente encuadrable en una u otra ${ }^{45}$.

Como trasfondo de los múltiples argumentos esgrimidos por la jurisprudencia civilista (partiéndose de la española, aunque aplicable a la de otros países), para defender la unidad de culpa ${ }^{46} \mathrm{y}$, en consecuencia, la acumulabilidad o alternatividad de regímenes (contractual o extracontractual), se halla la necesidad de materializar la justicia material ${ }^{47}$ a favor de las víctimas. Por loable que pueda resulta una eventual reivindicación de los derechos e intereses de los pasajeros, no puede obviarse la inseguridad jurídica ${ }^{48}$ resultan-

daño, según el cual los límites indemnizatorios establecidos en el Convenio no deben ser seguidos. El principal inconveniente de preferir la ley interna es el desconocimiento de la responsabilidad cuasi-objetiva.

${ }^{44}$ DíEZ-PICAZO, L. El Derecho de daños. Madrid: Ed. Civitas, 1999, pp. 246-249; y SANTOS BRIZ, «Unidad del concepto de culpa civil», en Perfiles de la responsabilidad civil en el nuevo milenio. Madrid, Dykinson, 2000, p. 596: «Siempre con la idea fundamental de acordar un resarcimiento de daños suficiente y justo en el caso concreto, viene a hacer pasar a un segundo término la dicotomía culpa contractual-culpa extracontractual».

${ }^{45}$ Los daños infligidos al pasajero pueden encuadrarse entre los incumplimientos contractuales que dan lugar a la responsabilidad contractual (art. 1101, C.C. Español), bien entre los incumplimientos del deber general -no convencional- de cuidado (art. 1902, C.C. Español).

${ }^{46}$ El principio de Unidad de Culpa se fundamenta en criterios de rango constitucional (tutela judicial efectiva) y legales (iuris novit curia). En definitiva, implica la posibilidad judicial de adaptar los fundamentos en Derecho a la acción respectiva, siempre que su naturaleza no se vea modificada, ni los hechos sobre los que el accionante la ejercita.

${ }^{47}$ «La jurisprudencia española, basada en la no consideración de la vida y la integridad física como objetos contractuales, se ha manifestado, con relación a los daños corporales, a favor de la calificación extracontractual (y por ende, extraconvencional) de la responsabilidad derivada de su producción en el transporte aéreo internacional de personas» (DE PAZ MARTín, Jesús, ob. cit., p. 127).

${ }^{48}$ La jurisprudencia española se ha pronunciado (sentencia SAP Baleares, de 2 de mayo de 2000, citada por DE PAZ MARTín, Jesús, ob. cit., p. 136) en el sentido de permitir al actor, en caso de probar culpa del agente, acogerse al régimen indemnizatorio general, incluso cuando ha incoado dentro del término de eficacia de la acción contenido en la Ley de Navegación Aérea -LNA-. Según dicha jurisprudencia, la eficiencia de la normativa específica depende del mayor o menor esfuerzo probatorio que realice el demandante; nada más contrario a la finalidad de uniformidad y permanencia de la normativa convencional. En otro pronunciamiento (sentencia SJPI de Bilbao N. ${ }^{\circ} 10$ de sept. 22 de 2003, AC 2003/1102, citada por De PAZ Martín, Jesús, ob. cit., p. 123), se llega al absurdo de descartar los límites resarcitorios convencionales, sin mayor argumento que el que la imperatividad del SV -aún no había entrado en vigor el CM 1999- solo recaía sobre la jurisdicción contencioso-administrativa, por ser dicha norma de Derecho público: «el contrato suscrito por las partes, muy intervenido, tiene naturaleza civil y por tanto las consecuencias administrativas pueden estar disciplinadas por el CV, pero en ningún caso la modulación de la indemnización procedente del incumplimiento contractual, reservada a los Tribunales civiles». Otros ejemplos no son menos desestimulantes; especialmente, las sentencias SAP Barcelona, de 
te de la «difuminación de la línea divisoria entre uno y otro régimen ${ }^{49}$ ». La ambivalencia de la doctrina respecto de la aplicación de uno u otro régimen de responsabilidad del transportista depende en últimas del sistema jurídico desde el cual cada autor razona ${ }^{50}$. Si bien es clara la naturaleza extracontractual de la responsabilidad del transportista frente a terceros en superficie ${ }^{51}(\mathrm{o}$, en su caso, la del fabricante de aeronaves respecto del pasajero), serán las peculiaridades de cada caso las que en últimas definan el régimen aplicable en supuestos de muerte o lesión de pasajeros ${ }^{52}$.

Ahora bien, el régimen convencional prescinde de la calificación de la responsabilidad de cara al ejercicio de las acciones; las cuales, a su vez, «se someten a unas condiciones (caducidad o prescripción, art. 29 del CM 1999), y a un régimen sustantivo específicos (límites indemnizatorios concretos,

13 de abril de 2002, AC 2002/2010 (en la que se desatiende el carácter internacional de la relación jurídica y se aplica el sistema autónomo cuando correspondía aplicar el convencional); la SAP Barcelona, de 20 de marzo de 2003, AC 2003/1354 (en la que se aplica uno u otro régimen dentro de un mismo supuesto, sin justificar dichas vacilaciones); la SAP Baleares de 9 de dic. de 2003, JUR 2003/92386 (en la que se insertan concepciones autónomas del ordenamiento jurídico español que resultaban de dudoso ajuste en el contexto normativo convencional, etc. (citadas por DE PAZ MARTín, Jesús, ob. cit., p. 123). En consecuencia, es fácilmente apreciable el papel especialmente distorsionador que ha desempeñado la jurisprudencia española durante la vigencia del anterior SV; falta ver si los yerros comentados se repiten bajo la actual normativa internacional.

49 Término acuñado por De PAz MARTín, Jesús, ob. cit., p. 127, en reemplazo del de «yuxtaposición» preferido por DíEZ-PICAZo, L. ob. cit., p. 262, para explicar que lo que en realidad se aprecia por parte de jurisprudencia española es un «traslado interesado» de un régimen a otro, con miras a una mayor defensa de las víctimas.

${ }^{50} \mathrm{Un}$ argumento esgrimido por quienes identifican la responsabilidad del transportista (en todos los supuestos) como extracontractual, es «la consideración de que la responsabilidad contractual nunca puede calificarse como subjetiva con inversión de carga de la prueba por la propia naturaleza de la relación contractual» (DE PAZ MARTín, Jesús, ob. cit., p. 130).

${ }^{51}$ Como intento de regulación internacional material de los riesgos a terceros se dio el Convenio de Roma de 1933 ( «Sobre la unificación de ciertas reglas relativas a los daños causados por las aeronaves a terceros en la superficie»), no vigente hoy. Hoy está el Convenio para la Unificación de Ciertas Reglas Relativas a los Daños Causados por las Aeronaves a Terceros en la Superficie (Conferencia Internacional de Derecho Privado Aéreo de Roma de 1952, la quinta de su clase, después de la de París [1925], Varsovia [1929], Roma [1933] y Bruselas [1938]; y del que forman parte 47 Estados (no EE. UU., Reino Unido, Francia, Japón). En su Preámbulo se consagran como principios el garantizar una reparación equitativa de las víctimas, pero «limitando cuantitativa y razonablemente la responsabilidad del transportista con la finalidad de no entorpecer el desarrollo del transporte aéreo internacional» (De Paz Martín, Jesús, ob. cit. p. 42). Hoy se busca modernizar tal instrumento, debido a su lenta implantación por parte de los Estados signatarios, la necesidad de eliminar los límites indemnizatorios, etc.).

52 «La vinculación de la conducta del causante del daño con la ejecución del contrato y la vinculación de daño con los intereses que el perjudicado ha concretado al contratar con el causante del mismo» (De PAZ MARTín, Jesús, ob. cit., p. 129). 
art. 22 del CM...), con independencia de que la fundamentación sea contractual o extracontractual, o de la naturaleza de los daños que pretendan ser resarcidos $^{53}$. Sin embargo, tal identidad no conlleva aceptar la aplicación cumulativa, subsidiaria o alternativa de las normativas convencional, foral, o conflictual, lo cual está expresamente prohibido por el CM $1999^{54}$, debiendo prevalecer los principios de legalidad, seguridad jurídica y iuris novit curia (especialidad) sobre el de justicia material.

En efecto, «sea cual sea la naturaleza de la acción y la calificación que el intérprete pueda otorgar a la responsabilidad dimanante, la yuxtaposición de la responsabilidad y las opciones de ejercicio de acciones no deben constreñir la determinación de las normas sustantivas aplicables, incluidos los límites indemnizatorios ${ }^{55} \gg$. En conclusión, esta ambivalencia fomenta el forum shopping, si consideramos que el modelo resarcitorio suele ser más benévolo en algunos Estados que en otros.

Por otra parte, la imperatividad del Derecho convencional se fundamenta en la Teoría de la Jerarquía Normativa, aplicable tanto en la esfera del Derecho Internacional Público como en el Privado. A nivel comunitario, es frecuente encontrar comentarios que alegan un «solapamiento de normativas». Ya se ha explicado la influencia recíproca entre la regulación de la realidad aeronáutica convencional y regional, así como el esfuerzo comunitario por adaptarse al nuevo CM 1999. Solo resta mencionar un hecho evidente: la liberalización comunitaria podría, eventualmente, revivir el cisma vivido durante el SV, toda vez que la autorregulación es entendida como necesaria para dicho propósito.

Finalmente, el «imperialismo legislativo» norteamericano ${ }^{56}$, propulsor del cisma irreconciliable resultante del CM 1966, se fundamenta en una idiosincrasia sobreproteccionista de los consumidores, en este caso, de los pasajeros. Deben precisarse algunas nociones.

En primer lugar, las notoriamente más elevadas condenas por parte de tribunales estadounidenses no implican, en sí mismas, un desconocimiento del Derecho convencional, si bien estimulan el fenómeno del bad forum shopping. En efecto, ni el SV ni el CM 1999 consagran criterio alguno de inclusión o exclusión de rubros del daño. Tal y como fueron diseñados tales instrumentos, los límites resarcitorios eran superables a través de un mayor

${ }^{53}$ De Paz Martín, Jesús, ob. cit., p. 131.

${ }^{54}$ La redacción del art. 29 CM (1999) (... solamente podrá iniciarse con sujeción a condiciones y límite de responsabilidad como los previstos en el presente Convenio», ha llevado a algunos a aceptar la teoría iusprivatista de la «equivalencia de resultados» según la cual, el Convenio aceptaría tácitamente el concurso normativo cuando la solución material que contienen den lugar a un resultado idéntico o equivalente». En este sentido, DE PAZ MARTín, Jesús, ob. cit., p. 231.

${ }^{55}$ De Paz Martín, Jesús, ob. cit., p. 133.

${ }^{56}$ AREAl LudeÑa, Santiago, ob. cit., p. 760. 
esfuerzo probatorio de las víctimas (que debían probar dolo o culpa cualificada en el SV), o de los agentes (en el CM 1999 que, se recuerda, diseña un régimen de culpa presunta simple por encima de tales límites); pero se dejó a la lex forum el reconocimiento de rubros que correspondiesen con realidades jurídicas autóctonas. Si bien es argüible que el modelo de responsabilidad convencional del transportista (para todos los supuestos; no solo para los de muerte y lesiones personales de pasajeros) es de naturaleza resarcitoria, no por ello puede desprenderse una clasificación rígida del daño.

En segundo lugar, debe refutarse la creencia según la cual el «daño punitivo» está inexorablemente prohibido por el régimen convencional. No obstante, y aunque se dejarán para la segunda parte de este trabajo, las matizaciones que, desde el análisis económico del Derecho pueden hacerse de esta peculiar manera de entender la responsabilidad; debe anticiparse que el «daño punitivo», más allá de la literalidad del vocablo, no siempre entraña una finalidad ejemplificante o sancionatoria de carácter penal. Es más, cuando esto ha sido asín ${ }^{57}$,

${ }^{57} \mathrm{El}$ único antecedente jurisprudencial norteamericano que, lamentablemente y en consideración a la lejanía de fuentes bibliográficas, se ha podido encontrar, relativo al reconocimiento de «daños punitivos» en los cuales, se persiga sancionar la conducta cuasi-dolosa del demandado (wilful misconduct), en abierto desconocimiento de la imperatividad del Régimen convencional (SV), es la referenciada como In re Korean Air Lines Disaster of September 1, 1983, 932 F.2d 1475 (D.C.Cir.1991), y analizada por LARSEN, Paul B; SweENEY, Joseph C.; y GuILlick, ob. cit., p. 405 (obtenible on-line en la dirección $<$ http://bulk.resource.org/courts.gov/c/F2/932/932.F2d.1475.89-5415.html>. -fecha de consulta, Nov. 15, 2008-). El actor apeló a lo expuesto en este trabajo, según el cual el SV remite a la Lex Forum, la inclusión de rubros del daño que respondan a realidades jurídicas autóctonas. Dada la naturaleza del daño punitivo, que, según se comprobará en la segunda parte de este estudio, no es siempre bien asimilada por los jurados norteamericanos; resulta claro la intención del actor: conseguir la mayor condena posible (nada más característico del bad forum shopping). En este caso se da obvia preferencia por el CM 1966; es decir, se predica un modelo de responsabilidad objetiva sujeto a las limitaciones que dicho instrumento recoge; pero apelando al SV (CV 1929 modificado por el PH 1955), en lo relativo a la posibilidad de superar los límites convencionales en presencia de dolo o culpa cualificada. El a quem se limita a la literalidad del art. 17 del SV, que establece un modelo de responsabilidad exclusivamente resarcitoria (liable for damage sustained); lo que, excluye, in limine, la posibilidad de reconocer rubros del daño con naturaleza diferente. Es interesante ver cómo, lo que se excluye, es la connotación preventiva del daño punitivo (Punitive damages as recognized by federal courts as retributive and deterrent in nature, Cons. 6); dejando abierta la posibilidad del daño punitivo, en su connotación compensatoria. Resalta también la irrelevancia que en el Common Law tiene la calificación de la responsabilidad como contractual o extracontractual, dado que «lo que importa es la reparación del daño... tal es el sentido de la Convención»-Cons. 10-, traducción no oficial). Basa la Corte, igualmente, su decisión en el análisis comparado de otros ordenamientos que, como el inglés y el alemán, admiten daños punitivos, pero se abstiene de ello en aras de salvaguardar la uniformidad del texto convencional. Esta sentencia abre las puertas al daño punitivo de connotación sancionatoria y preventiva, cuando no se configuren los criterios de aplicación del SV; es decir, cuando lo que se aplique sea el Régimen General («si el transportista destruye su propia aeronave, con el propósito fraudulento de cobrar el seguro, no podrá cobijarse de la 
el propio sistema judicial norteamericano ha corregido tal distorsión en salvaguarda del Derecho convencional ${ }^{58}$.

El problema está en la ausencia de límites previsibles de esta herramienta (propia de un ordenamiento que, como el Common Law, depende de la jurisprudencia para elaborar sus reglas); circunstancia que hace aún más compleja la figura. En efecto, es defendible, al menos desde un plano meramente académico, la inclusión de rubros del daño, denominados como punitivos, y compatibles con la finalidad reparadora del CM 1999; aunque tales constituyan mecanismos forales a través de los cuales se materialicen políticas públicas correctivas de muchas de las falencias del Modelo Civilista Continental del Derecho de Daños; como quiera que el formalismo procedimental de tal Modelo, la mayoría de las veces, contraviene la plena reparación de perjuicios.

No obstante, debe considerarse la amenaza de que, habida cuenta de la especial influencia (no solo académica, sino también de muchos de los operadores jurídicos) que la disciplina económica ejerce sobre el Derecho en EE. UU., se pudiese desvirtuar la eficiencia económica de las reglas convencionales de responsabilidad del transportista aéreo internacional, en especial en supuestos tan sensibles como los de muerte y lesiones personales de pasajeros; se suscita un nuevo rompimiento similar al ya experimentado respecto del SV.

\section{Descripción normativa y reglas de responsabilidad: del SV al CM 1999}

Entre los mayores aciertos del CM 1999 se encuentra el haber compilado en un único texto el Derecho convencional ${ }^{59}$ (tan disperso en el anterior

protección que le proporciona la Convención de Varsovia, toda vez que no se configura el elemento material de conexión definido como accidente»-Cons. 20-, traducción no oficial. Finalmente, y muy a pesar de la contundencia que caracteriza este pronunciamiento, permanece la duda acerca de si esta interpretación constituye regla jurisprudencial. En efecto, en el Salvamento de Voto se cita un pronunciamiento de la Supreme Court para sostener todo lo contrario: en esencia, que la inclusión de cualquier rubro del daño es discrecional del jurado, al cual la propia Convención le permite remitirse a criterios legeforistas de interpretación (se cita el caso Smith v. wade, 462 U.S. 30, 36 n. 5, 103 S.Ct. 1625, 1629 n. 5, 75 L.Ed.2d 632 -1983- ). Lamentablemente, no se ha podido encontrar esta sentencia.

${ }^{58}$ Corrobora esta afirmación el detallado análisis jurisprudencial que hace LARSEN, Paul B; Sweeney, Joseph C.; y Guillick, John E. Aviation Law: Cases, Laws and Related Sources. New York: Ed. Transnational Publishers, Inc, 2006, pp. 277-294.

${ }^{59}$ De PAz MARTín, Jesús, ob. cit., p. 390: «Es necesario advertir que dicha seguridad -la derivada de un régimen unificado de responsabilidad-puede volverse en contra de los intereses... -de las víctimas-, ya el automatismo judicial en las reclamaciones y en el otorgamiento de las indemnizaciones atendiendo al límite de 100.000 DEG puede transformar esa cantidad en un referente inalterable, incluso en los supuestos en los que los daños ocasionados y probados superan dicha cifra». 
$\mathrm{SV}$ ), respetando los principios que inspiraron otros instrumentos normativos nacidos en sede autorreguladora y supranacional ${ }^{60}$.

De manera sucinta, puede describirse el modelo convencional de la responsabilidad civil del transportista aéreo internacional en caso de muerte y lesiones personales de pasajeros como objetivo reforzado (en consideración a las causales de exoneración), hasta el límite pecuniario fijado en 100.000 DEG; por encima del cual se convierte en subjetivo con inversión de carga probatoria. De lo anterior, sobresalen las aristas fundamentales del sistema: objetividad y limitación. Analizaremos a continuación los diferentes matices del régimen instaurado por el CM 1999, sin obviar las reglas previas del SV.

\subsection{Responsabilidad objetiva}

La configuración de la responsabilidad del transportista como objetiva tiene como fundamentación política un criterio de justicia distributiva, esto es, «la reparación del daño provocado como consecuencia de una actividad profesional que entraña unos riesgos específicos ${ }^{61}$ tiene como verdadera finalidad la de dar respuesta a una exigencia de equilibrio entre el usuario y el empresario transportista ${ }^{62} \gg$. En efecto, a pesar de que los avances tecnológicos han aminorado el riesgo aeronáutico, la alta siniestralidad de los accidentes (junto a ciertas prácticas específicas -overbooking, retrasos-) sigue siendo un factor determinante en la regulación del transporte aéreo.

Ahora bien, la objetividad definida por el CM 1999, si bien es reforza$d a^{63}$, no es total. En primer lugar, se admite la culpa del pasajero (no el hecho) como causal de exoneración o atenuación de responsabilidad del

${ }^{60}$ En estricto sentido, el CM 1999 fue poco innovador, por cuanto recoge modificaciones ya incorporadas en instrumentos normativos previos.

${ }^{61}$ No cabe duda de que los riesgos aeronáuticos son cualitativamente cualificados en relación con los de otros medios de transporte. En efecto, no solo debe valorarse la alta siniestralidad de la actividad, sino también la interdependencia de otros operadores privados y públicos, tales como las autoridades de control, los controladores de vuelo, etc.

${ }^{62}$ De Paz Martín, Jesús, ob. cit., p. 138.

${ }^{63}$ La teoría clásica de la responsabilidad predica como causales de exoneración a los que puede apelar el agente demandado diversas modalidades de causa extraña; entre las que figuran el hecho o la culpa exclusiva (o concurrencial, según la exoneración sea parcial) de la víctima, la fuerza mayor, el caso fortuito, el hecho de un tercero, y el estado de necesidad (entendido de manera muy distinta a como lo hace el Derecho penal). No sobra advertir que la causa extraña rompe lo que la doctrina denomina «presunción de responsabilidad» (que no es igual a la presunción de imputación subjetiva o culpa, cuya primera defensa es la diligencia); es decir, destruye el nexo causal. Salvo algunos matices (que no vienen al caso analizar), lo anterior se aplica indistintamente a la responsabilidad contractual y extracontractual, en especial si aplicamos principios procesales y constitucionales ya explicados en relación con la unidad de culpa. Ver TAMAYO JARAmillo, Javier. Tratado de responsabilidad civil, Tomo II. Bogotá: Ed. Legis, 2007, pp. 59 y ss. 
transportista aéreo (art. 20 CM 1999), independientemente de los límites resarcitorios. En segundo lugar, la objetividad se atenúa considerablemente más allá de los límites mencionados, permitiéndosele al agente demostrar su diligencia $^{64}$. En tercer lugar, el Convenio diferencia los regímenes en los que la diligencia tiene como efecto exonerar o disminuir la responsabilidad del transportista; concretamente los supuestos de retrasos (en los que la diligencia exigida es cualificada, Art. 19 CM 1999), y muerte o lesiones de pasajeros (diligencia simple por encima de los límites reparadores, art. 21, a). En cuarto lugar, y en consideración a la especial naturaleza del riesgo asumido, se autoriza al transportista para negarse a contratar (o ejecutar lo pactado, según cada caso) cuando estime, razonablemente ${ }^{65}$, que se pude incrementar dicho riesgo.

La evolución de las reglas de responsabilidad por muerte y lesiones a los pasajeros ha sido, dentro del sistema de responsabilidad en el transporte aéreo, la más destacable si se atiende a las modificaciones sufridas ${ }^{66}$. El CV 1929 consagraba un sistema de responsabilidad subjetiva con inversión de carga de la prueba ${ }^{67}$, y sujeto a límites pecuniarios (art. 20.1 CV 1929), excepto en casos de dolo o culpa grave ${ }^{68}$, para los que debían atenderse criterios legeforistas ${ }^{69}$. Su modificación no se hizo esperar. En el seno de orga-

${ }^{64} \mathrm{Si}$ bien parece un contrasentido describir el régimen convencional de responsabilidad contenido en el art. 21 del CM 1999, por encima de los 100.000 DEG, como objetivo (tradicionalmente la doctrina habla de un régimen de culpa presunta), no podría explicarse de otra forma su literal $b$, en el cual se describe una causa extraña (culpa -no el hecho- de un tercero). En efecto, el régimen de culpa presunta presupone la eficacia de todas las causales de exoneración de responsabilidad; por cuanto, si se permite al agente demostrar su diligencia, mal haría el legislador en limitar un esfuerzo probatorio mayor, como quiera que tal supone el desvirtuar el nexo causal. Es así como puede pensarse en el evento en que el transportista obre con negligencia en la valoración de los efectos de un caso fortuito, pero pueda a su vez demostrar que es este el que finalmente desencadena el siniestro. Si se analiza con rigor científico el texto convencional, en tal evento el transportista deberá ser condenado más allá de los límites indemnizatorios; situación que contradice el régimen de presunción de culpa. Por ello se estima mejor describir el modelo, por encima de tales límites, como objetivo atenuado, y no como subjetivo con inversión de carga probatoria, como tradicionalmente suele hacerse.

${ }^{65}$ Si bien el CM 1999 no condiciona dicha facultad, es claro que las modalidades de incumplimiento contractual siguen las soluciones legeforistas.

${ }^{66}$ De Paz Martín, Jesús, ob. cit., p. 377.

${ }^{67} \mathrm{La}$ regla del art. 17 del CV 1929 fue incorrectamente incorporada por algunos Estados (caso español), hasta el punto en que el modelo de responsabilidad del transportista se asimiló al del fabricante, es decir, se interpretó como objetivo, y se distorsionó así la finalidad unificadora del SV, hecho que contribuyó a su posterior ruptura.

${ }^{68}$ Antes del CM 1999, el daño intencional se configuraba como la única cláusula de escape de las limitaciones indemnizatorias.

${ }^{69}$ En los arts. 17, 20, 21 y 22 del texto original del CV 1929 se preveía que a la víctima correspondía probar el daño (la prueba no era necesaria en caso de allanamiento por parte del demandado, según criterio acuñado por la jurisprudencia de algunos Estados, como el 
nizaciones internacionales de origen interestatal (CITEJA y luego OACI) y sectorial (IATA) se impulsaron reformas que vinieron a materializarse en los Protocolos de la Haya de $1955^{70}$, y de Guatemala de 1971. No obstante, y como ya se había anticipado, tales protocolos no lograron satisfacer los intereses de algunos Estados que, de manera directa e indirecta, los desconocieron $^{71}$. Otros Estados, como EE. UU., Japón y Reino Unido, impulsaron dos reformas en el marco de procesos de autorregulación.

Retomando el modelo instaurado por el CM 1999, la doctrina lo define como «dual» (two-tier system). Esto significa que, hasta un límite de 100.000 DEG (equivalente hoy a $135.000 €$ ), la responsabilidad es objetiva reforzada; por encima del cual se instaura un régimen de culpa probada ${ }^{72}$ no cualificada $^{73}$. Esto implica que cuando el daño probado sea menor al límite, la objetivización juega paralelamente a favor de la víctima ${ }^{74}$. El nuevo mode-

español) y el nexo causal (que este se resultaba de un accidente acaecido en el curso de «todas las operaciones de embarque o desembarque»); mientras que al demandado (transportista, y respecto de sus dependientes), para efectos de eximir su responsabilidad, competía demostrar su diligencia cualificada («todas las medidas necesarias para evitar el daño o que les fue imposible tomarlas»), o bien la culpa concurrencial de la víctima (exoneración total o parcial de responsabilidad). En cuanto a los límites, se consagraba, salvo en caso de dolo o culpa grave del transportista o sus dependientes, el de 125 mil francos-oro, aunque tal límite podía ser contractualmente desconocido por las partes.

${ }^{70}$ Son tres las principales reformas incorporadas por el PH 1955: 1. Se duplica el límite indemnizatorio (art. 11 modificatorio del art. 22 CV 1929). 2. Se define las nociones de dolo y culpa grave, anteriormente dejadas a la interpretación legeforista (art. 13: «El daño es resultado de una acción u omisión del transportista o de sus dependientes, con intención de causar daño, o con temeridad y sabiendo que probablemente causaría daño»). 3. Se permite una condena adicional en costas procesales, cuando el demandado no se hubiese aprestado a transar extrajudicialmente. Sobre el PH 1955, se sugiere consultar DiEDERIKS-VERSCHOOR, ob. cit. p. 151.

${ }^{71}$ El PH 1955 no modificó el régimen de culpa presunta del texto original, para supuestos de daños personales de pasajeros (muerte y lesiones). Su único avance relativo a la objetivización de la responsabilidad del transportista se da con relación al transporte de mercancías y equipajes (AREAl LudeÑa, Santiago, ob. cit., p. 433). La verdadera ruptura normativa, si bien no conceptual (por cuanto esto se da a través del AM 1966), respecto del CV 1929, se dio a través del Protocolo de Guatemala (en adelante, PG 1971), a través del cual se consagra un régimen de responsabilidad objetiva para supuestos de muerte o lesiones personales de pasajeros; posteriormente recogido, en lo sustancial, por el CM 1999. Lamentablemente, El PG 1971 tuvo poca acogida internacional (España, por ejemplo, no lo ratificó).

${ }^{72}$ Ver pie de página $\mathrm{N}^{\circ} 50$.

${ }^{73}$ Cuando «el daño no se debió a la negligencia o a otra acción u omisión del transportista o de sus dependiente» (art. 21.1 CM 1999). A pesar de la literalidad del texto transcrito, algunos autores han entendido que la diligencia exigida al transportista para eximir su responsabilidad, por encima del límite establecido, es «máxima» (o cualificada; similar a la descrita en el art. 19 del CM 1999 para eventos de retraso). Ver De PAZ MARTín, Jesús, ob. cit., p. 380.

${ }^{74}$ Por esto puede hablarse de un sistema de responsabilidad «delimitado», y «no limitado», en función de la cuantía de los daños personales reclamados y probados por el pasajero (De Paz Martín, Jesús, ob. cit., p. 381). 
lo se diferencia del anterior SV precisamente por el carácter ilimitado de la responsabilidad cuando el transportista no pueda desvirtuar la presunción de culpa que sobre él recae ${ }^{75}$ (recuérdese que la superación de los límites contenidos en el anterior SV solo era posible si la víctima lograba demostrar dolo o culpa cualificada del agente).

Se procederá ahora a profundizar en el análisis de aspectos puntuales de las reglas descritas, concretamente el de los daños indemnizables, la especial connotación del nexo causal ${ }^{76}$ y el período durante el cual el transportista asume los riesgos de su actividad.

El CM 1999 no se limita al resarcimiento de los daños físicos ${ }^{77}$, sino también a los morales ${ }^{78}$. Si bien es recomendable acudir a la lex fori ${ }^{79}$ para incluir rubros no materiales del daño ${ }^{80}$, no por ello puede suponerse abierta

${ }^{75}$ El modelo de responsabilidad del CM 1999 disminuye la judicialización de controversias, por cuanto admite la posibilidad de una condena en costas al demandante que no se hubiese prestado a resolver extra-juicio las reclamaciones (art. 22.6 del CM 1999).

${ }^{76}$ Descrito brillantemente por AREAL LudEÑA, Santiago, ob. cit., p. 776: «Así, no existirá verdadera relación de causalidad si pueden convivir de manera independiente daños a la persona y accidente, es decir, si se le asigna al transportista la responsabilidad, por las consecuencias de aquellos accidentes, acaecidos fuera del curso habitual en la ejecución del contrato. Con otras palabras, si el daño no es más que una reacción física a unas conductas ya conocidas que se realizan durante el vuelo, no se puede hablar de cause of accident como sucede, por ejemplo, en los supuestos de aerofobia».

${ }^{77}$ Con relación al reconocimiento de daños psíquicos, AREAL Ludeña, Santiago, ob. cit., p. 772, es partidario de la no inclusión de tales rubros en el CM 1999, por analogía de la solución arribada por un grupo de expertos de la OACI en el año de 1951, respecto del SV.

${ }^{78}$ De Paz Martín, Jesús, ob. cit., p. 382

${ }^{79}$ Se ha estudiado cómo la valoración legeforista de los rubros del daño indemnizables incentiva el bad forum shopping, sobre todo cuando el transportista no consigue desvirtuar la presunción de negligencia que le endosa la norma convencional, habida cuenta de que los límites convencionales devienen inaplicables. No obstante, existen otros criterios que, si bien no son tan abiertamente aceptados, ronda en la mente de juristas y estudiosos: la nacionalidad de las víctimas. Tal criterio, discriminatorio a simple vista, ha sido constantemente «camuflado» por tribunales donde es natural encontrar elevadas condenas. El matiz radica en la interpretación que pueda hacerse del concepto «lesiones personales» (bodily injuries), acuñado por el CM 1999. Si bien es uniforme (tanto en la jurisprudencia continental como del Common Law) la aceptación de lesiones a la salud mental, al igual que otros tipos de angustia psíquica o moral, directamente asociadas a «daños físicos», es igualmente frecuente encontrar ambivalencias en la aceptación de tales rubros, cuando se presentan aisladamente. En el caso Beck et al. V.KLM Royal Airlines and Ritz Travel, la Corte del Estado de New York, apartándose de su propia jurisprudencia (ver el análisis que del derrotero jurisprudencial sobre este punto hace DIEDERIKS-VERSCHOOR, ob. cit., p. 142), e interpretando restrictivamente el art. 17 de la CM 1999, deniega las pretensiones del accionante, bajo el argumento de que los daños inmateriales solo son indemnizables cuando se presentan asociados con los físicos. Las dudas surgen cuando se aprecia la nacionalidad de las víctimas (Hungría). En similar sentido, ArEal LudeÑa, Santiago, ob. cit., p. 760.

${ }^{80}$ De Paz Martín, Jesús, ob. cit., p. 383. 
la posibilidad para desconocer los límites resarcitorios convencionales. No obstante, parece debatible, al menos en algunos ordenamientos del Common Law, la posibilidad de incluir rubros del daño no necesariamente resarcitorios; se puede incluso interpretar (como en efectos se ha hecho), que el texto convencional no cercena la facultad del Estado signatario para limitar el alcance de sus políticas de control social, máxime si el sistema de responsabilidad coadyuva tales políticas ${ }^{81}$.

Debe aclararse que el hecho dañino debe ser el resultado de un «accidente» para que se configure la responsabilidad. El alcance conceptual de «accidente» está implícitamente delimitado en la propia Convención ${ }^{82}$. En efecto, la única ${ }^{83}$ causa extraña que contempla el CM 1999 como válida para desvirtuar el vínculo objetivo de imputación jurídico de responsabilidad del agente, por encima de los límites pecuniarios del Art. 17, es la culpa de un tercero $^{84}$ (art. 21.2, b). Ahora bien, del propio Convenio se desprende el

${ }^{81}$ En el caso Pescatore v. Pan Am, 2d Cir., 1996, citado por DiEDERIKS-VersChoor, ob. cit., p. 141, la Corte de Nueva York (EE. UU.), apelando a sus reglas de conflicto, admitió la aplicación de la Normativa Civil del Estado de Ohio, en la cual se reconocían los denominados «daños a la sociedad» (Loss of Society), a través de los cuales se canalizan políticas públicas de protección a intereses colectivos de especial connotación.

${ }^{82}$ No se comparte la interpretación «rígida» que del concepto «accidente» hacen algunos autores (definido como «todo hecho que, además de ser ajeno a la esfera de actuación del pasajero, sea inesperado, inusual, repentino»; ver DE PAZ MARTín, Jesús, ob. cit., p. 384). La regla objetivizada de responsabilidad por encima de los límites resarcitorios convencionales, no se vería desvirtuada en caso de que la propia Convención, directa o indirectamente (por ejemplo, remitiendo la definición de «causa extraña» a la ley del foro) aceptase causales de exoneración que rompiesen el nexo causal de la relación indemnizatoria. Lo que sucede es que la Convención, al incluir únicamente la «culpa de un tercero», establece una cláusula de cierre al intérprete respecto de otras «causas extrañas». Tal interpretación debe estimarse excesiva y alejada de la literalidad del texto convencional. En sentido contrario, ver Botana AgRa, M., La ilimitación de la responsabilidad del transportista aéreo comunitario por daños a los pasajeros en caso de accidente: un estudio del Reglamento (CE) 2027/1997. Madrid: Ed. Marcial Pons, 2000, p. 45, que interpreta el concepto «accidente» como inclusivo de supuestos propios de la navegación aérea (causas extrañas tales como la turbulencia).

${ }^{83}$ La complejidad técnica y la especial connotación del comandante de la aeronave fueron, bajo la vigencia del anterior SV, frecuentemente esgrimidas como causales exonerativas de responsabilidad por parte de transportistas y académicos. Veremos, en la segunda parte de este estudio, cómo la dificultad probatoria relativa a factores técnicos justifica el modelo de responsabilidad objetiva (es económicamente eficiente que la prueba recaiga sobre quien tiene el control del riesgo); al tiempo que el control público de pilotos («regulación del mercado» como mecanismos de «socialización» del daño») fue tenido en cuenta en CV 1929 (art. 20) para exonerar al transportista («falla náutica»), en supuestos de responsabilidad del transportista por pérdida de equipajes.

${ }^{84}$ Dado que la culpa de la víctima, causa extraña por antonomasia, exonera, total o parcialmente, la responsabilidad del transportista, en todo momento, con independencia de los límites del art. 17 (art. 20, del CM 1999). 
carácter no concurrencial (solo exonera totalmente) de la culpa (no hecho) de un tercero (art. 21,2, b). Esto nos prueba la anterior aseveración de que el régimen delimitado por el CM 1999 es objetivo reforzado, por cuanto excluye causales que en la teoría general de la responsabilidad (al menos en el Derecho civil codificado) servirían de exonerantes, tales como la fuerza mayor y el caso fortuito.

Esto de no debe confundirse con la diligencia (y por ende, la ausencia de dolo o culpa grave) que, predicable también respecto de dependientes y agentes del transportista ${ }^{85}$, exime su responsabilidad por encima de los límites resarcitorios (art. 21.1 del CM 1999).

En relación con el lapso durante el cual asume los riesgos de su actividad, la Convención delimita el «período de responsabilidad» del transportista como aquel que va desde las operaciones de embarque hasta las de desembarque. Esto no supone la irresponsabilidad del operador aéreo en estadios extemporáneos, sino simplemente la aplicación del régimen general. Ahora bien, tal período se concreta a aquel en el cual el transportista tiene control $^{86}$ de la actividad del pasajero. Dicha «esfera de actividad» determina no solo el régimen legal aplicable (convención o ley material aplicable en virtud de normas de conflicto), sino también la culpa concurrencial del pasajero como limitativa de la responsabilidad del transportista.

\subsection{Responsabilidad limitada}

El desarrollo de la industria aeronáutica se estimó, a comienzos del s. Xx, estrechamente relacionado con el desarrollo económico de los Estados ${ }^{87}$. Esto,

${ }^{85}$ La modulación que hace el art. 22.5 del CM 1999, relativo al dolo o culpa cualificada del transportista, sus dependientes o agentes, como requisito para obviar los límites indemnizatorios en los eventos de retraso e incorrecto transporte de equipaje, en el entendido de que estos han debido actuar en el «ejercicio de sus funciones», no es extensible a los de muerte y lesiones personales de pasajeros.

${ }^{86}$ Esto significa que si, por ejemplo, el daño ocurriese durante el período de espera, en eventos de retraso, suspensión o cancelación de vuelos, dicho accidente estaría inserto en el ámbito temporal de aplicación de la Convención (considérese «embarque») siempre que el transportista pudiese influir de manera determinante en el comportamiento del pasajero, con independencia de que luego alegase como exonerante de su responsabilidad su culpa concurrencial.

${ }^{87}$ Entre otros argumentos aportados por la doctrina para limitar, e incluso disminuir los límites convencionales, destacan los siguientes: 1. La naturaleza externa de los riesgos implícitos en la actividad aeronáutica, en especial las condiciones meteorológicas. 2. La necesidad de homogeneizar legalmente situaciones personales y materiales dispares. 3. La compensación del beneficio probatorio que conlleva un régimen de responsabilidad objetiva. 4. Mayor seguridad jurídica (predecibilidad del daño) para evitar el forum shopping. 5. El previo conocimiento de los riesgos por parte del pasajero. 6. El mayor beneficio para los pasajeros ante una disminución de las tarifas, por cuanto una menor responsabilidad disminuiría los costes de la industria. 7. La mayor liberalización del sector, dado que los lími- 
unido a la efectiva ${ }^{88}$ protección de los pasajeros, fundamentó la limitación de la responsabilidad; la cual, se ha visto, no se dio en el texto original del CV 1929. Como es apenas lógico, esta limitación, entendible como mecanismo de «intervencionismo público directo de mercados» conlleva un reparto o socialización de los riesgos inherentes a la actividad aeronáutica.

Los límites indemnizatorios convencionales no vulneran (ni el SV ni el CM 1999), per se, el principio de reparación integral del daño ${ }^{89}$; toda vez que no suponen una tasación automática de este, por cuanto solo se aplican cuando el daño real los supere ${ }^{90}$. Por el contrario, se ha esgrimido la posibilidad de flexibilizar tales límites en supuestos de daños intencionales (dolo o culpa equiparable ${ }^{91}$ ).

tes evitaban que los Estados no subsidiasen a sus compañías como mecanismo para asumir los altos riesgos. 8. Equivalencia entre las prestaciones de los contratantes el carácter conmutativo del contrato de transporte. 9. La evicción de demandad temeridad (menor litigiocidad). (De Paz Martín, Jesús, ob. cit., p. 149).

${ }^{88}$ No puede perderse de vista que la limitación de la responsabilidad repercute directamente en el aseguramiento de los riesgos inherentes al transporte aéreo internacional. En efecto, la alta siniestralidad de la actividad impedía que aseguradoras los cubriesen de manera ilimitada. Para no abandonar las garantías de los usuarios a la suerte financiera de una industria naciente, más que para hacer viable el éxito de las compañías aseguradoras, fue que se valoró la importancia de limitar la responsabilidad de los transportistas aéreos como mecanismo de socialización de tales riesgos.

${ }^{89}$ Debe advertirse que la posibilidad de superar los límites indemnizatorios en los supuestos del art. 21,2 del CM 1999 solo se aplica a la responsabilidad del transportista por muerte o lesiones personales de pasajeros.

90 «En definitiva, a priori, se desconoce si puede darse una reparación integral o parcial del daño» (DE PAZ MARTín, Jesús, ob. cit., p. 147).

${ }^{91}$ La graduación de la culpa responde, necesariamente, a criterios legeforistas. Mientras que en sistemas jurídicos codificados la culpa grave o inexcusable equivale al dolo; en los de Common Law se diferencian conceptos tales como gross negligence (nuestro equivalente a «culpa grave»), y wilful misconduct; el cual es «completamente diferente a la negligencia, y la supera con independencia de la graduación que se le dé» (caso Goepp v. American Overseas Airlines, New York Supreme Court, Appellate Division, 16 Dec. 1952; citado por DiEDERIKS-VERSCHOOR, ob. cit., p. 153). La precisión terminológica resulta fundamental para efectos de admitir el reconocimiento de daños punitivos, dado que, y como se verá en la segunda parte de este trabajo, estos rubros del daño pueden eventualmente coincidir con finalidades complementarias a la reparación misma. En efecto, en relación con el daño intencional, debe anticiparse que el concepto de wilful misconduct no es la única modalidad de imputación subjetiva de aquel (sino que también lo configura la gross negligence). Si de buscar su equivalente en el Sistema Continental de corte «civilista» se trata, podría sostenerse que la wilful misconduct comparte elementos definitorios tanto del dolo, como la culpa grave: a conscious intent to do or to omit doing the act from which harm results to another, or intentional omission of a manifest duty. There must be a realization of the probability of injury from the conduct, and a disregard of the probable consequences of such conduct (DIEDERIKS-VERSCHOOR, ob. cit., p. 154). 
Una crítica recurrente en la doctrina tiene que ver con la inadecuación económica de los límites convencionales, a modo de déjà vu del anterior SV: «(...) si el principal argumento para la limitación de la cuantía indemnizatoria en 1929 era el de la problemática situación económica a la que se hubieran visto abocadas las originarias compañías aéreas, cuando las circunstancias evolucionaron favorablemente hacia los intereses de esas y su asentamiento económico fue una realidad, debe plantearse el por qué los Estados han mantenido un sistema de responsabilidad limitada y con modificaciones puntuales de las cuantías indemnizatorias que no se han ajustado a dicha evolución: quizás por los excesivos riesgos vinculados con la navegación aeronáutica, por la existencia de las denominadas compañías bandera y los aportes económicos de estas a las distintas economías nacionales, o quizás por la fuerza "mediática" de las compañías aéreas privadas respecto de los diversos legisladores nacionales ${ }^{92} \gg$.

Acerca de la adecuación o no de tales límites, puede defenderse su función niveladora de los beneficios que el régimen objetivo proporciona al pasajero; de allí que, a través de mecanismos autorreguladores, las compañías aéreas hayan obviado tales límites, pero condicionándolo a la prueba de la negligencia del transportista ${ }^{93}$.

Más allá de justificar o no la limitación de la responsabilidad que ha caracterizado el Derecho aéreo convencional, lo que sí deviene claro es que ello constituyen el epicentro del fracaso histórico del anterior SV. Su inadecuación obedece, además de a fundamentaciones de índole económica, a la «rigidez» consecuencial de la ausencia de mecanismos eficaces de corrección. Con independencia de los argumentos jurídicos que la jurisprudencia de distintos países habría podido esbozar ${ }^{94}$, no se debe incurrir en el error de incorporar tendencias «sobreproteccionista»-de usuarios- foráneas (coma la que se impone con fuerza en el modelo norteamericano), en desmedro de limitaciones connaturales al régimen legal de reparación, como, por ejem-

${ }^{92}$ De Paz Martín, Jesús, ob. cit., p. 150.

${ }^{93}$ Hay autores que consideran sensato modificar el actual régimen convencional, por uno subjetivo (con o sin inversión de carga probatoria) e ilimitado. Ver Mapelli, E. El contrato de transporte aéreo internacional. Comentarios al Convenio de Varsovia. Madrid: ed. Tecnos, 1968, p. 312.

${ }^{94}$ La jurisprudencia española apeló a diversos argumentos para obviar los límites resarcitorios durante la vigencia del SV, pero sin apartarse formalmente del sistema. El primero de ellos es el de la primacía constitucional del principio de reparación integral del daño (en la sentencia SJPI, de Bilbao, de 14 de marzo de 1997, AC 2003/253, comentada por DE PAZ MARTín, Jesús, ob. cit., p. 152; se definen los límites como «mínimos», cuando la finalidad del SV era establecerlos como «máximos»). Un segundo argumento es el de la teoría de la clasificación de los rubros del daño (en la sentencia SJPI de Barcelona, N. ${ }^{\circ}$ 31, de 13 de diciembre de 2001, AC 2001/921, comentada por De PAZ MARTín, Jesús, ob. cit., p. 153; se circunscriben dichos límites a los daños «materiales directos»; si bien se trataba de un supuesto de responsabilidad del transportista por extravío de equipaje). 
plo, la prohibición del enriquecimiento sin causa, imperante en sistemas civilistas.

Equivocado sería defender la tesis abolicionista de los límites convencionales ${ }^{95}$. En efecto, tal eliminación atentaría contra, no solo la viabilidad económica de la industria aeronáutica (más en la actualidad, ante los riesgos latentes del terrorismo internacional); sino también contra la cobertura de riesgos, pues como se ha explicado, son precisamente los límites indemnizatorios los que posibilitan su socialización. Es por ello por lo que el CM 1999 optó, por incrementarlos y actualizarlos ${ }^{96}$ (art. 24), en lugar de abolirlos.

Por su parte, la teoría niveladora parece sostenible; habida cuenta de la protección complementaria de los intereses del pasajero, a través de mecanismos tales como el régimen objetivizado de responsabilidad, la obligación de aseguramiento de los transportistas que aspiren obtener licencias de explotación ${ }^{97}$ (al menos es así en la UE), y la posibilidad de superar dichos

${ }^{95}$ Areal LudeÑA, Santiago, ob. cit., p. 762, analiza el actual contexto económico de la industria aeronáutica europea, a la luz del llamado que hace la Asociación de Líneas Aéreas Europeas, relativa a una serie de «necesidades mínimas» para que «el sector salga a flote»; entre las que figuran el reforzamiento de un sistema estable de seguros contra acciones de guerra y terrorismo, disminución de las tarifas de aeropuertos y centros de control de tráfico aéreo, etc. Lo anterior, para enfatizar que, si bien ya se han superado las históricas precariedades del sector aéreo que justificaron los primeros intentos normativos internacionales, su actualidad dista mucho de estar plenamente consolidada.

${ }^{96}$ El CM 1999, art. 24, dota al sistema de mecanismos «ordinarios» y «extraordinarios» de ajuste, con base en el índice inflacionario ponderado entre los Estados signatarios con monedas vinculadas a los DEG (Estados miembros del Fondo Monetario Internacional, FMI), y con periodicidad quinquenal. Con relación al referente monetario, el originario franco-oro fue sustituido en los Protocolos de Montreal (1 y 3) por el DEG, el cual fue ratificado por el CM 1999. Para aquellos Estados que no pertenezcan al FMI, el Convenio establece el oro como referente subsidiario (art. 23 CM 1999).

${ }^{97}$ La necesidad de garantizar el buen funcionamiento del seguro aeronáutico ha sido una de las razones para la consagración de un régimen de responsabilidad limitada. En efecto, el seguro funciona como diversificador por antonomasia de los riesgos propios de la actividad aeronáutica, y las aerolíneas son las llamadas a transmitir los costes de tales riesgos a los usuarios a través de las tarifas. El establecimiento de límites indemnizatorios cuantitativos de la responsabilidad ha supuesto que las compañías aéreas pudieran conocer de antemano, aunque no de manera taxativa, los riesgos que, en términos cuantitativos y vinculados con los sujetos u objetos transportados, asumían. La limitación también servía como criterio a considerar por las aseguradoras, para cubrir riesgos asociados a la siniestralidad de la actividad, de otra manera difícilmente asegurables (riesgos derivados del contrato de transporte). En el CM 1999 (art. 50), se exige a los Estados parte que obliguen a sus respectivas compañías aéreas a cubrir los riesgos que crean, y el modelo convencional de responsabilidad es el único parámetro. Es más, aún no considerándose una compañía aérea estatal, es decir, con licencia de vuelo otorgada por el Estado correspondiente, se «podrán» exigir «pruebas de que mantiene un seguro adecuado, que cubre su responsabilidad en virtud del presente convenio». Esta remisión nos lleva a la normativa comunitaria contenida en el R. 2407/92/CE, en el cual se establece como requisito para el otorgamiento de las licencias aéreas la suscripción de seguros, en particular, respecto a los pasajeros, el equipaje, la carga; 
límites cuando medie negligencia del agente ${ }^{98}$ (al igual que la de condena en costas que consagra el CM 1999 en su art. 22,6).

\subsection{Supuestos no regulados por la norma convencional ${ }^{99}$}

El principal reto de toda normativa internacional es el conciliar, de manera armónica y coherente, tradiciones jurídicas divergentes y, la mayoría de las veces, contradictoria. La complejidad intrínseca y extrínseca del transporte aéreo dificulta aún más la ya ardua tarea conciliatoria del Derecho convencional.

La técnica legislativa más recurrida para hacer frente a las discrepancias naturales entre sistemas jurídicos es la de regular lo estrictamente necesario, permitiéndoles a los Estados, grupos de Estados y organizaciones privadas, el desarrollo, aplicación e interpretación del modelo axiológico básico, marco definido por el instrumento uniforme.

No obstante, dicha técnica es de casi imposible aplicación. A continuación se analizarán las inconsistencias regulatorias del CM 1999, sus implicaciones relativas al bad forum shopping, los mecanismos jurídicos de ajuste, bajo una perspectiva general de valoración de su éxito futuro.

\subsubsection{CONFLICTUALISMO FRENTE A LEGEFORISMO ${ }^{100}$}

Más allá de interpretar las remisiones normativas convencionales como lagunas jurídicas, puede afirmarse que las cuestiones no reguladas por el

y se remiten a la normativa de cada Estado miembro las condiciones para cumplir estas medidas. Finalmente, debe recalcarse la especial coyuntura internacional actual. El riesgo de terrorismo, a partir del 2001, fue prácticamente inasumible por las aseguradoras, lo que demandó una maximización de la intervención pública para sostener la industria (asumiendo los propios Estados tales riesgos o el incremento en las pólizas -sobre tales subsidios o ayudas públicas y su conciliación con el Mercado Común, el R. 785/2004/CE-). Más sobre el seguro aeronáutico en De PaZ MARTín, Jesús, ob. cit., pp. 53 y ss.; y ArEal LudeÑa, Santiago, El seguro aeronáutico. Especial referencia a la responsabilidad del fabricante de productos defectuosos. Madrid: ed. Colex, 1998.

${ }^{98} \mathrm{Sin}$ desconocer los riesgos de aplicar posturas jurisprudenciales tales como la de «unidad de culpa», que distorsiona la finalidad perseguida por el Derecho convencional.

${ }^{99}$ La regulación indirecta se da por remisión expresa del CM 1999 a la lex fori, por ejemplo, en los arts. 22.6 (reconocimiento de costas procesales e intereses, independientemente de los límites indemnizatorios), 33.4 (cuestiones de procedimiento), 35.2 (cómputo de los plazos de las acciones) y 45 (denuncia de juicio que el demandado, transportista contractual o de hecho, hiciere contra el otro, no demandado); o la ley del prestador característico, art. 28 (pago -o prestaciones- anticipado en los supuestos de lesión o muerte de pasajeros para cubrir las necesidades económicas urgentes de quien tuviere derecho a incoar acción de responsabilidad, si así lo exigiere la ley nacional del transportista). Por su parte, el art. 56.3 del CM 1999 prevé que la remisión debe hacerse a la «ley de la unidad territorial pertinente de ese Estado», en especial consideración del Derecho comunitario.

${ }^{100}$ Expresión tomada de De PaZ MarTín, Jesús, ob. cit., p. 112. 
Derecho uniforme son básicamente de índole interpretativa, y que «están vinculadas con otras cuestiones que sí están reguladas en dichos convenios ${ }^{101} »$; por ejemplo, la definición de «retraso», o «accidente», la valoración del nivel de diligencia requerido para efectos de exoneración de responsabilidad, la extensión de daños indemnizables (rubros cubiertos), o la propia naturaleza de la responsabilidad (si se incluye la responsabilidad meramente «resarcitoria», «niveladora» o incluso «punitiva»o «correctiva»).

Es aquí donde surge el debate acerca del mecanismo más idóneo para solucionar las eventuales «deficiencias» $\mathrm{o}$ «carencias que pudiesen presentar los textos convencionales a nivel interpretativo: legeforismo o conflictualismo» ${ }^{102}$. La doctrina se inclina por la primera solución, es decir, aquella que aplica un mismo marco interpretativo en el sistema jurídico donde se discuta el caso (foro). Esta solución, que parece acertada, incrementa el riesgo del bad forum shopping, tal y como se ha explicado.

Ahora bien, no deben interpretarse como «lagunas» aquellas conceptualizaciones «abiertas», propias de todo texto convencional con expectativa de universalidad (o uniformidad); sino, todo lo contrario, como indispensables para que más Estados se adhieran a tal norma, al tiempo que puedan desarrollar sus propias concepciones de justicia material. Adicionalmente, más allá de la particularización interpretativa de conceptos abiertos, y en relación con las verdaderas lagunas, la solución legeforista «garantiza la homogeneidad interpretativa ad intra ${ }^{103} \gg$.

\subsubsection{SUPUESTOS DE RESPONSABILIDAD DEL TRANSPORTISTA AÉREO INTERNA- CIONAL NO REGULADOS EN LOS REGÍMENES SUSTANTIVOS}

El Derecho convencional del transporte aéreo internacional se refiere a incumplimientos contractuales relativos a supuestos de inejecución parcial. Tanto el CV 1929 como el CM 1999 «presuponen, al menos, la voluntad inicial del transportista de cumplir con sus obligaciones contractuales adquiridas, dejando por fuera de su regulación los supuestos de inejecución total del transporte ${ }^{104} \gg ;$ lo cual no significa, per se, el descarte de daños intencionales directos o por conexión (culpa cualificada).

101 «El problema, respecto a esas cuestiones, es determinar no la ley aplicable, sino el ordenamiento jurídico bajo el cual debe realizarse la interpretación», por tratarse de cuestiones sustantivas reguladas pero «abiertas» a distintas interpretaciones (DE PAZ MARTín, Jesús, ob. cit., p. 113).

${ }^{102}$ Solución que implica encontrar el ordenamiento jurídico que está detrás de la relación jurídica específica que da lugar a la responsabilidad, con independencia de si es o no la ley del foro. De Paz MarTín, Jesús, ob. cit., p. 114.

${ }^{103}$ Por lex fori debe entenderse tanto la lex contractus como la ley Extra-contractus, DE PAZ MARTín, Jesús, ob. cit., p. 116.

${ }^{104}$ De Paz Martín, Jesús, ob. cit., p. 116. 
En relación con estos supuestos, adquiere relevancia el régimen conflictual iusprivatista establecido a través del Convenio de Roma de 1980 (en adelante CR 1989), y el R. (CE) 44/2001, relativos a la ley aplicable, la competencia judicial internacional y la ejecución de resoluciones judiciales en material civil y mercantil, respectivamente.

Antes de aplicar las referidas reglas conflictuales, el operador jurídico deberá calificar la responsabilidad como contractual o extracontractual ${ }^{105}$, en aquellos supuestos no incluidos en el ámbito de aplicación material del texto convencional; que, como se ha explicado, se relacionan con conductas dañinas intencionales o cuasi-delictuales.

Posteriormente, surge la cuestión de la acumulación de acciones ${ }^{106}$; lo cual influye en aquellos ordenamientos con dualidad de regímenes, en lo relativo a la valoración del daño (y los supuestos objetivos y subjetivos que la afectan). Este punto cobra importancia no solo respecto de aquellos daños directos derivados de una conducta dañina calificada como extracontractual, sino también de los indirectos enmarcados en un incumplimiento de tipo contractual (lo que podría valorarse en última instancia como responsabilidad extracontractual). En ambos casos la solución es la misma: inaplicación

${ }^{105}$ El primer problema que plantea la calificación de la responsabilidad como contractual o extracontractual es el del ordenamiento estatal con arreglo al cual el juez debe hacerla. Más allá de que la solución legeforista se resuelva en España de manera legal (art. 12.1, C.C.); lo cierto es que, entre los criterios que permiten calificar la responsabilidad (seguidos mayor o menormente por cada ordenamiento estatal), figuran la existencia previa de un contrato, los fundamentos de la pretensión (rubros del daño que se reclaman), la conducta dañina del transportista (que la culpa contractual cualificada pueda asimilarse a dolo extracontractual o delictual), la previsión del daño en el momento de la contratación, etc. (DE PAZ MARTín, Jesús, ob. cit., p. 118).

${ }^{106}$ Existen dos teorías (al menos en la jurisprudencia española) opuestas relativas a la admisibilidad de acciones, según se rechace o no («teoría de la no acumulación» y «teoría de la opción»). No sobra advertir que el debate cobra vigencia solamente en aquellos ordenamientos en los que la diferenciación entre responsabilidad contractual y extracontractual deriva consecuencias dispares en relación con el daño resarcible (e incluso de naturaleza no resarcitoria). En caso de no existir diferenciación relevante respecto al monto del daño asociado a la previa existencia o no de un vínculo contractual, como, por ejemplo, en el sistema del Common Law (no se pretende afirmar que en el Common Law el régimen normativo no aplica reglas específicas a supuestos de responsabilidad contractual, sino que la calificación de regímenes no influye en la valoración objetiva del daño), la normativa aplicable a aquellos supuestos no reglados por el texto convencional será siempre la misma: el régimen común. En el caso español, la admisibilidad de ambas acciones, aunque no clara, parece desprenderse de la aplicación de principios de justicia material y no denegación de justicia (sentencia SAP de 24 de julio de 2002, JUR 2003/247105, comentada por DE PAZ MARTín, Jesús, ob. cit., p. 119. En dicha sentencia se admite el carácter alternativo del ejercicio de la acción; pero, en caso de haber sido ejercidas ambas acciones de manera conjunta, la contractual basada en la Convención y la extracontractual en el régimen común, se da preferencia a la primera). 
de los montos de responsabilidad convencionales, y favorecimiento del bad forum shopping.

Debido a que la aplicación de normas iusprivatistas de conflicto para los supuestos no regulados por la normativa convencional ${ }^{107}$ influye directamente en la práctica de bad forum shopping, se estima oportuno comentar sus principales características.

En relación con la competencia judicial internacional, debe explicarse que, en primer lugar, las reglas conflictuales parten del respeto a la autonomía de la voluntad de las partes, a la hora de señalar el tribunal competente ${ }^{108}$; y, claro está, atendiendo a la naturaleza contractual de la responsabilidad derivada del incumplimiento total del transportista. En ausencia de jurisdicción pactada, deberán atenderse los demás factores determinantes de los foros generales ${ }^{109}$, tales como el domicilio del demandado, o el lugar de cumplimiento de la obligación que da lugar a la acción. Ahora bien, tratándose de responsabilidad extracontractual (no ya de incumplimiento absoluto del contrato), o en el supuesto de yuxtaposición de regímenes, y concurrente con los foros generales, se encuentra el forum delicti comissi o del lugar del hecho dañino, contenido en el art.5.3 del R. 44/2001/CE ${ }^{110}$.

${ }^{107}$ El art. 33 del CM 1999 es la norma base para establecer el tribunal competente de aplicar el Convenio: «1. Una acción de indemnización de daños deberá iniciarse, a elección del demandante, en el territorio de uno de los Estados parte, sea ante el tribunal del domicilio del transportista, o de su oficina principal, o del lugar en que tiene una oficina por cuyo conducto se ha celebrado el contrato, sea ante el tribunal del lugar de destino.

2. Con respecto al daño resultante de la muerte o lesiones del pasajero, una acción podrá iniciarse ante uno de los tribunales mencionados en el párrafo $1 .^{\circ}$ de este artículo, o en el territorio de un Estado parte en que el pasajero tiene su residencia principal y permanente en el momento del accidente y hacia y desde el cual el transportista explota servicios de transporte aéreo de pasajeros en sus propias aeronaves o en las de otro transportista con arreglo a un acuerdo comercial, y en que el transportista realiza sus actividades de transporte aéreo de pasajeros desde locales arrendados o que son de su propiedad o de otro transportista con el que tiene un acuerdo comercial...».

${ }^{108}$ Esta libertad contractual no es absoluta. Tales cláusulas de elección de foro están sometidas a requisitos de forma y fondo, tales como aquellas garantías de equilibrio contractual (no abuso de la posición de dominio), aunadas a la normativa de protección del consumidor, que le imprimen una mayor protección al consumidor (proximidad de la jurisdicción pactada con el consumidor).

${ }^{109}$ R. 44/2001, art. 5.1 (con ámbito de aplicación exclusivamente europeo); y en caso español, el art. 22.3 de la LOPJ (forum celebrationis). Sobre la interpretación realizada por el TJCE del art. 5.1 del Convenio de Bruselas de 1968 (en adelante, CB 1968), en el que se establece el forum executionis, la sentencia STJCE de 28 de sept. de 1999, asunto C-440/97 (Rec. P. I-6307), apela a la denominada «doctrina Tessili». Más en De PAZ MarTín, Jesús, ob. cit., pp. 121 y ss.

${ }^{110}$ La LOPJ recoge un foro adicional al delictivo, a través del cual se reconoce competencia judicial a los tribunales españoles cuando el autor del daño y la víctima tengan residencia habitual común en España (definido por la doctrina como forum communis). Más en De Paz MarTín, Jesús, ob. cit., p. 121. 
Para determinar la ley aplicable ${ }^{111}$, el CR 1980 también recoge el principio de autonomía de la voluntad (art. 3). Lo expuesto en relación con las garantías formales y materiales relativas a la elección de jurisdicción es igualmente aplicable a la cláusula de ley aplicable. Igualmente, el CR 1980 presume como la ley más próxima al contrato la del prestador característica, lo cual, matizado al contrato de transporte internacional de pasajeros, hace referencia a la del lugar donde el transportista tiene su establecimiento principal ${ }^{112}$.

\section{Análisis económico del daño intencional}

Tal y como se ha explicado en la primera parte de este trabajo, la imputación subjetiva cualificada (dolo o culpa grave), constituía la única posibilidad que consagraba el SV para superar los límites indemnizatorios. A pesar de las modificaciones introducidas por el CM 1999, relativas a la introducción de un modelo de culpa presunta, tales nociones perdieron relevancia jurídica. Sin embargo, del análisis económico de la responsabilidad civil se desprende que el daño intencional sí puede repercutir en la valoración del daño, especialmente en aquellos sistemas jurídicos donde se reconocen «daños punitivos». En este acápite, se procederá a repasar las diferentes doctrinas relacionadas con la valoración económica de las diversas reglas de responsabilidad legales, su adecuación comparativa entre ordenamientos jurídicos, las distintas connotaciones del daño intencional (sus mecanismos de medición y corrección), para posteriormente valorar, en concreto, la eficiencia del reglas convencionales del CM 1999.

\subsection{Introducción al análisis económico de la responsabilidad}

El análisis económico del derecho de daños parte de un enfoque ex ante o conductista, en el cual se le otorga escasa importancia al problema ex post de recompensar a las víctimas por el daño causado. La función resarcitoria puede ser adecuadamente cubierta por sistemas alternativos, como el de

${ }^{111}$ Con relación al transporte internacional de pasajeros, es conveniente precisar que, además de las reglas conflictuales establecidas en el CR 1980, existen ámbitos de responsabilidad regulados materialmente al margen de la normativa convencional; concretamente, supuestos de overbooking y cancelación de vuelos, regulados por el R. 261/2004, en el Derecho comunitario. En supuestos de responsabilidad extracontractual, y más ella de los esfuerzos comunitarios de armonización legislativa, es claro que la determinación de la ley aplicable recae en las reglas de conflicto nacionales. En el caso español, el art. 10.9 del C.C., prevé como aplicable la lex loci delicti comissi. De cualquier modo, la solución mayoritariamente aceptada por la doctrina (y jurisprudencia española) es la legeforista.

${ }^{112}$ Para el transporte de mercancías, el CR 1980, art. 4.4, prevé acumulativamente la ley del lugar de carga, la de destino, y la del establecimiento principal del transportista, a elección del expedidor. 
seguros. Se plantea como finalidad primordial de la norma, sea cual fuere su origen o forma, la provisión de incentivos, no solo para prevenir el daño, sino para hacerlo de manera socialmente eficiente, es decir, a un mínimo coste.

Son dos los agentes cuyo comportamiento puede verse alterado por este sistema de incentivos: la víctima y el causante. Se supone que entre ellos no existen vínculos contractuales y que los costes de negociación son prohibitivamente elevados, de manera que se obvia la cooperación como recurso. En consecuencia, se espera que la norma consiga que el agente y la víctima internalicen los costes producidos por sus actuaciones; ofrezca incentivos para la adecuada inversión en recursos de prevención; defina estándares óptimos de alocación de tales recursos; establezca mecanismos de disuasión cuando la prevención no sea posible; corrija la incertidumbre producida por eventuales fallas en la valoración de las diversas variables a aplicar; y provea causales de exoneración ante determinadas conductas dañinas pero socialmente beneficiosas, así como la eficiente externalización pública del coste.

Deben distinguirse dos categorías de accidentes: los unilaterales, definidos como aquellos para los cuales la víctima no puede alterar el riesgo, y los bilaterales. Se define prevención como el conjunto de medidas que cualquiera de las partes puede tomar para reducir la frecuencia de los incidentes o la magnitud de los daños ocasionados. Se plantea que tomar precauciones es una actividad que tiene coste. El resultado de multiplicar la probabilidad de ocurrencia del accidente $(p)$ por el daño ocasionado cuando este ocurre $(D)$ se conoce como daño esperado $(L)$.

En términos generales, se predica una relación decreciente entre los montos $(x, y)$ gastados en prevención y la probabilidad $(p)$ de ocurrencia de daños y, además, que los actores conocen esta relación. Así, se estima que tanto la probabilidad del accidente, $p(x, y)$ como el daño esperado $(L)$ son funciones decrecientes en $(x, y)$. La prevención se define por unidad de actividad y se señala que una segunda vía para alterar la probabilidad de algunos accidentes son los distintos niveles de actividad asociada con los riesgos.

El análisis económico de las reglas de responsabilidad no se limita a diferenciar, como lo hace el derecho civil, entre responsabilidad subjetiva (negligence) y objetiva (subjetiva); su mérito radica en profundizar sus estructuras para definir los mecanismos más apropiados en aras de dos objetivos centrales: prevención y disuasión.

Así, por ejemplo, hay modelos de culpa cualificada que no encuadra temáticamente en la regla subjetiva del daño, sino que, por su entidad propia, merece una respuesta correctiva; y según la gravedad de la conducta del agente, la corrección se dará por medio de una revaloración del estándar de cuidado, o de un aumento de los daños compensatorios, en algunos casos de gross negligence; bien por medio de verdaderos daños punitivos en los casos más extremos de insensibilidad preventiva, como los de recklessness.

Así, lo que prima facie será un caso típico de daño intencional, donde la regla aplicable resulta irrelevante, podría ser finalmente resuelto a través 
de mecanismos correctivos del nivel asumido de prevención. Igualmente, hay conductas verdaderamente dolosas en las que la disuasión no es prohibitiva por el beneficio social reportado. Aquí radica la complejidad del método económico, propio de sistemas basados en el precedente: las reglas se construyen con base en la casuística, sin verdades previamente reveladas.

Lo anterior no impide que puedan describirse casos típicos de cada regla. Por ejemplo, la responsabilidad será objetiva en aquellas situaciones donde la prevención solo puede ser eficientemente asumida por el agente, porque es él quien controla el riesgo creado por su actividad. Debido a que será el daño el único parámetro a considerar en la cuantificación de la condena, se predica que el agente solo internalizará los costes mínimos para que su daño no se convierta en intencional, es decir, para que no se reconozcan rubros sancionatorios del daño. Es así como la imputabilidad subjetiva solo tendrá importancia para efectos de daños no resarcitorios; contrario a sistemas de corte civilista continental, donde el comportamiento del agente jamás se tiene en cuenta.

Otro supuesto clásico de inaplicabilidad del principio de reparación integral es aquel de no responsabilidad. La ausencia de responsabilidad implica un panorama dual: por una parte, están los casos de externalización del daño, en los que son modelos de seguridad social los que asumen tales costes; o aquellos donde es la propia víctima la que internaliza el coste, debiendo internalizar exclusivamente niveles de prevención. Esta última hipótesis pugna contra los mínimos de justicia, razón por la cual es de esperar que solo procedan de errores en la valoración judicial de estándares de prevención, como uno de los muchos contextos generadores de incertidumbre.

Por su parte, la incertidumbre se erige como la principal causa de regulación pública, respuesta externa y alternativa de los correctivos que ofrece el Common Law, como por ejemplo, las causales de exoneración o atenuación de la responsabilidad. En consecuencia, solo frente a modelos ciertos, o sea, aquellos donde la norma de cuidado está eficientemente determinada por la disposición jurídica, y en los que su ejecución es plenamente predecible, las causales de exoneración carecen de relevancia práctica. El análisis económico del Derecho de daños es consciente de la imperfección del sistema en los órdenes expuestos, por lo que defiende mecanismos de corrección internos y externos.

Pero la incertidumbre no siempre es mala. Por ejemplo, solo en presencia de incertidumbre es justificable, desde una perspectiva económica, que la víctima asuma niveles mínimos de prevención. Esto es fácilmente comprobable: los arreglos legales de negligencia ofrecen incentivos para que los causantes adopten los niveles de prevención establecidos como estándares; en la medida en que el estándar legal coincida con el valor que minimiza los costes totales, el nivel de prevención adoptado será eficiente en términos económicos. Si la regla se ejecutara sin margen de error, el agente no care- 
cería de incentivos para asumir costes mayores; y la víctima, menores al estándar normativo. Esto desencadenaría dos posibles e indeseables resultados: que los actores asumieran costes insuficientes, o bien, excesivamente altos de prevención; desde todo punto de vista, ineficientes.

La incertidumbre en el modelo de culpa simple (negligence) hace previsible en la víctima la probable responsabilidad del agente, lo que la llevaría a internalizar costes eficientes de prevención; y por parte del agente, a limitar su confianza en mecanismos de exoneración (como por ejemplo, que la víctima sea negligente -contributory negligence-), incentivándole para que adapte su conducta a los niveles preestablecidos por la norma.

La complejidad del análisis no solo versa sobre el estándar óptimo de prevención (optimal due care), sino también en el daño a indemnizar. No existe, en la economía de los accidentes, una regla general sobre fijación eficiente de las indemnizaciones para todas las situaciones que implican un daño. Los criterios sugeridos para establecer tales montos dependen de la naturaleza del daño (y en particular si se afectan bienes reemplazables o irreemplazables), de la relación entre los actores, del tipo de riesgo, de las reglas de responsabilidad, de si la responsabilidad es individual o vicaria, término que se utiliza para aquellos casos en los cuales un tercero se hace responsable por los daños cometidos por el causante. También se tiene en cuenta si existen o no limitaciones de información, incertidumbre o insolvencia de los responsables.

Puede reconocerse que las mayores dificultades para determinar teóricamente un monto de las indemnizaciones que satisfaga criterios de eficiencia se da cuando el daño implica bienes no sustituibles, o prohibitivamente reemplazables. La doctrina civilista no es ajena a esta problemática cuando diferencia, aunque en un plano meramente teórico, entre resarcimiento y compensación como especies del género reparación. En efecto, la determinación eficiente del daño se relaciona con el nivel de actividad del agente, más que con la regla de la responsabilidad. Son diversos los métodos propuestos para valorar rubros empíricamente incuantificables, tales como el la regla de equivalencia del riesgo, la regla del la reciprocidad, la regla del incremento del daño, la regla del daño completo, etc. La dificultad aumenta según la finalidad económica perseguida: prevención o disuasión.

Muchas de las actuales tendencias de ordenamientos jurídicos de tipo continental, tales como la objetivización de nuevas realidades, la pretasación del daño o su limitación como mecanismo de homogeneización (v.gr. en supuestos de responsabilidad del fabricante por productos defectuosos, tratamiento del mal denominado daño ambiental, regulaciones de actividades transfronterizas como la del transporte aéreo, etc.), carecen, en su mayoría, de justificación económica (aunque su profundización exceda el objeto del presente estudio, no sobra decirlo). Lo único cierto es la influencia ideológica y política en la evolución interpretativa del Derecho, pasando de un pri- 
mer enfoque preventivo, contenido en las primeras codificaciones, a uno enfocado casi que exclusivamente en la reparación de las víctimas ${ }^{113}$.

No se quiere decir con esto que el Derecho deba estar ajeno a valoraciones ideológicas, sociales, de ética o de moral (las cuales deben necesariamente influir en su evolución); sino recalcar la importancia de objetivizar, en la medida de lo posible, su eficiencia en la consecución de objetivos de prevención y disuasión. El debate es álgido en ambos lados del Atlántico. En el sistema anglosajón, por ejemplo, son frecuentes las críticas a lo que la doctrina denomina contaminación estatutaria, a la cual culpan de incentivar la industria a costa de las víctimas, distorsionar la adecuada aplicación de reglas contenidas en el precedente o, contradictoriamente, impedir una adecuada redistribución de la riqueza. Por su parte, en el sistema continental, se critica la creciente punitividad del daño, vía incremento emotivo de ciertos rubros del daño ${ }^{114}$, lo cual afecta, para algunos, en el crecimiento económico, pero sin reparar consistentemente a las víctimas.

Finalmente, la predictibilidad del daño (lo cual es posible tanto legalmente como a través del seguimiento no distorsionado del precedente) es una

${ }^{113}$ Para la caricatura más simplista del conflicto de prioridades entre prevención e indemnización, se puede recurrir al enfrentamiento entre posiciones ideológicas de izquierda y derecha. Para la posición individualista extrema, el foco de atención debe ser el causante. Esta consideración se basa en la vieja noción de responsabilidad personal: cada quien debe comprometerse ante la ley por sus acciones; y tan solo pensar en abolir la idea de obligación por daño causado simplemente va en contra de uno de los pilares del sistema de intercambio liberal. Para la ideología de izquierda, preocupada por la solidaridad, por la seguridad de los trabajadores y por promover un Estado de bienestar, la atención debe, por el contrario, centrarse en las víctimas de los accidentes, quienes tienen derecho a algún tipo de beneficio, entendido como una simple extensión del sistema de seguridad social. Además se considera, bajo el prisma de la izquierda, que los daños son con frecuencia causados por grandes corporaciones o entidades públicas que deben mantenerse bajo control, haciéndoles pagar las consecuencias de sus excesos. Es, en efecto, importante filtrar el análisis del Derecho de ideologías cambiantes y limitadas; si lo que se persigue es entender reglas claras, objetivas y con alguna vocación de continuidad.

${ }^{114}$ La definición judicial de las indemnizaciones por daños morales, por ejemplo, genera una mayor disparidad en sus montos que puede acarrear como consecuencia un incremento en la litigiocidad. Además, se retrasa el momento del pago y se encarecen financieramente las indemnizaciones. Por parte de las compañías de seguros se argumenta que la incertidumbre sobre los pagos de indemnizaciones impide hacer un cálculo adecuado de las reservas y, por esta vía, se afecta la solvencia financiera del sistema. No menos importante, se considera ineficiente que, dependiendo del tribunal que se encargue del caso, se llegue, para incidentes de naturaleza comparable, a indemnizaciones radicalmente distintas. Además, parece inevitable la tendencia a un incremento permanente, sin ningún tipo de cota objetiva, tanto en el monto de las indemnizaciones que se conceden como en la lista de incidentes susceptibles de pagos por concepto de rubros inmateriales o sancionatorios del daño. Lo anterior afecta, de manera diferente, claro está, tanto al sistema jurídico anglosajón como al continental; de ahí la relevancia del análisis económico del daño, como instrumento científico de solución y adecuación de la norma a nuevas realidades sociales. 
necesidad más apremiante tratándose de daños sancionatorios. La doctrina reconoce, cada vez más, la eficiencia económica de mecanismos extrajudiciales de arreglo de diferencias, para lo que es fundamental el que los actores puedan anticiparse al daño, en cualquiera de sus esferas. No menos importante, se establecería un freno a condenas exorbitantes, que agrava más las diferencias entre ordenamientos jurídicos, y favorece el fenómeno del forum shopping.

\subsection{Hacia una definición económica de 'Intencionalidad'}

Tanto el Common Law como el Derecho estatutario de algunos Esta$\operatorname{dos}^{115}$ contemplan daños sancionatorios, adicionales a los resarcitorios o compensatorios, en conductas catalogadas como intencionales, sin mayor profundización. Corresponde por ello al análisis económico del Derecho establecer qué conductas, definibles legalmente como intencionales, no son susceptibles de corrección sancionatoria.

En efecto, deben estudiarse las distintas acepciones del vocablo, cada una con su respectiva consecuencia jurídico-económica:

\subsubsection{CONSCIENCIA DEL SINIESTRO, PERO SIN ÁNIMO DE CAUSACIÓN NI DESEO DE LUCRO CONSECUENCIAL}

$\mathrm{L}(x, y)=p(x, y) \mathrm{D}+\mathrm{A}(x)+\mathrm{B}(y)^{116} \rightarrow$ ecuación referida a una víctima específica. Si se tomase en consideración un número de víctimas indeterminado $^{117}(n)$, puede apreciarse que el nivel de cuidado debido por el agente,

${ }^{115}$ El caso del Código civil de California, en el que se ejemplifican la malicia, la opresión y el fraude como conductas intencionales en las que se deben declarar daños punitivos: «... As used in this section, the following definitions shall apply:

"...Malice means conduct which is intended by the defendant to cause injury to the plaintiff or despicable conduct which is carried on by the defendant with a willful and conscious disregard of the rights or safety of others.

"... Oppression means despicable conduct that subjects a person to cruel and unjust hardship in conscious disregard of that person's rights.

"...Fraud means an intentional misrepresentation, deceit, or concealment of a material fact known to the defendant with the intention on the part of the defendant of thereby depriving a person of property or legal rights or otherwise causing injury». Ver en $<$ http://law.justia.com/california/codes/civ/3294-3296.html>, 5 de Octubre de 2008.

${ }^{116} \mathrm{El}$ daño esperado por víctima es igual a la probabilidad del siniestro multiplicado por el daño efectivamente ocurrido, más el coste de prevención, tanto de la víctima A como del agente del daño B.

${ }^{117}$ El ejemplo traído por el autor es: «(...) si la probabilidad de no siniestro en un viaje es $(1-p)$, la de un solo accidente en $n$ viajes es $(1-p) n-a$ la $n-$, (asumiendo cada viaje como un evento independiente). Por lo tanto, la probabilidad de al menos un siniestro en el conjunto de viajes es $1-(1-p)$ n». P. 151 . 
en términos de prevención (reducir la probabilidad de accidentes) se mantiene inalterado y que, salvo en s de economías de escala aplicables ${ }^{118}$, el mayor o menor número de víctimas en nada repercute ${ }^{119}$; motivo por el cual esta acepción de intencional carece de relevancia jurídica.

Apréciese como esta acepción de intencional, como equivalente a altamente probable, no justifica reglas de responsabilidad más o menos automáticas o punitivas. Deben, por lo tanto, excluirse actividades que involucren un bajo nivel de probabilidad de daño, al tiempo que un coste desproporcionadamente bajo de prevención. En efecto, cualquier argumentación en contrario pierde sustento en el caso de actividades con bajo riesgo pero acometidas con el deseo de dañar, caso en el cual el resultado podría predicarse como «intencional», pero solo si se toman en cuenta otras variables (además de la probabilidad), tales como la severidad, el ánimo, el coste de prevención, etc.

En otras palabras, no deviene eficiente un incremento por parte del agente (destinatario último de la normativa intervencionista de prevención) en su nivel de cuidado, dado que, si bien el daño es anticipable, el coste beneficio en la relación actividad (se espera productiva) y víctimas resultaría injustificablemente alto (entendiendo que el número de víctimas por actividad también es predecible).

\subsection{2. ÁNIMO DE PROVOCAR UN RESULTADO DAÑINO, PERO SIN CONSCIENCIA DE ILEGITIMIDAD}

El nivel eficiente de cuidado se traslada del agente a la propia víctima. Un ejemplo típico lo encontramos en la legítima defensa ${ }^{120}$. Es apreciable que el nivel de cuidado que ha de emplear el agente para evitar el resultado dañino excede no solo el daño esperado, sino también, y por mucho, el nivel de cuidado de la víctima, dado que el análisis debe incluir el daño que el propio agente espera evitar defendiéndose.

Es por esto por lo que una adecuada política de prevención debe aumentar el input de prevención en la víctima, por ejemplo, exonerando de responsabilidad al agente. Dado que el coste de prevención de los actores es dema-

${ }^{118}$ En la sentencia citada por el autor (Conway v. O'Brien), se toma en consideración la prevención a escala de daños, en relación con actividades de la cuales se esperan daños. En dicha sentencia se sostiene que «(...) el nivel de cuidado esperado es una función que depende de tres variables: la probabilidad de daños a otros, la extensión del siniestro en caso de ocurrir, y el test de eficiencia en términos del sacrificio empleado en evitar el riesgo» (151).

${ }^{119}$ El nivel de cuidado debido por el agente, en relación con la probabilidad del daño, viene representado por la siguiente ecuación $-n p y D=n B y$, donde se aprecia que el número de víctimas potenciales no determina el input de prevención por parte del agente; o si lo hace, no de forma relevante para una eventual adopción de políticas de intervención pública.

${ }^{120}$ LANDES y Posner, ob. cit. pp. 35-40. 
siado bajo y que afecta positivamente al índice de probabilidad del daño, sería socialmente costeso adoptar otro tipo de políticas públicas disuasivas.

\subsection{3. ÁNIMO Y CONSCIENCIA DE PROVOCAR UN RESULTADO QUE SE SABE ES ILE- GÍTIMO}

Bajo esta acepción, si bien la probabilidad de ocurrencia del daño no es menor que en las anteriores, es claro que el coste social de disuasión exter$n a$ del daño es menor que el beneficio social reportado; considerándose todas las variables estudiadas, tales como los inputs de prevención del agente y de la víctima, la probabilidad de siniestro, su coste, el número de víctimas, etc.

\subsection{Hacia un modelo del daño intencional}

En los daños intencionales, debe considerarse la utilidad que el daño le reporta al agente (así como lo haría él mismo), así: $\mathrm{L}(x, y)=p(x, y)(\mathrm{D}-\mathrm{G})$ $+\mathrm{A}(x)+\mathrm{B}(y)^{121}$.

En supuestos de responsabilidad basada en la culpa, donde la ganancia es inexistente $(\mathrm{G}=0)$, la ecuación demanda un input de prevención tanto en el actor como en la víctima; en cambio, mediando dolo en la causación del daño, se parte del supuesto de que la ganancia esperada por el agente es positiva (quiere el daño e invierte recursos para ello $-p>0-$ ), es decir, $\mathrm{G}>0$, donde $G$ es el incentivo para producir el resultado ${ }^{122}$.

Ahora bien, deben diferenciarse dos situaciones distintas, según la ganancia esperada sea menor $(G<D)$, mayor o igual $(G \geq D)$ que el daño esperado. No se trata solo de un confuso juego de signos y números, sino de las bases para determinar una política pública de prevención eficiente. En el primer supuesto, es claro que la utilidad tendrá un carácter eminentemente privado, radicado en cabeza del agente; y que para que la probabilidad sea cero $(\mathrm{p}=0)$, siguiendo la ecuación en análisis, la inversión en prevención por los actores de la relación resarcitoria deberá también ser inexistente. En otras palabras, dado que para que la víctima neutralice la inversión positiva que el

${ }^{121}$ Donde $G$ es la utilidad que el agente espera reportar del daño.

122 Piénsese tan solo en signos numéricos: mediando culpa, $G=0$ y eso convierte a $p$ en un valor negativo, dado que todo daño $D$ se piensa a priori como una deducción. Ello hace necesariamente negativas las erogaciones en prevención que emplean los actores de la relación resarcitoria, entiéndanse víctima y agente, pues $L$ es, por definición, un valor negativo. Por su parte, si media intención del victimario, es decir, si este espera un beneficio del daño, $G>0$ (aunque no necesariamente mayor que el perjuicio en sí mismo), modificándose los signos anteriormente descritos, manteniendo como variables constantes una actitud al menos pasiva de la víctima, y el daño total esperado $L$ negativo; de lo cual concluimos que forzosamente la «erogación» en prevención que realiza el agente será un valor positivo, es decir, en lugar de invertir, lo que este espera es una utilidad neta de su actividad. 
agente realiza en la ocurrencia del daño deberá erogar -negativo- hasta el nivel de ganancia por este esperado $(G)$, incrementándose el daño esperado $(L)$, lo que significa ineficiencia social, la disuasión debe presentarse a través de un modelo legal que haga responsable al agente, en monto no inferior al daño esperado ${ }^{123}$. El segundo supuesto, un poco más complejo, versa sobre daños socialmente eficientes, y será estudiado con posterioridad.

El problema de la eficiencia social en la prevención de daños, parte del supuesto de que el daño es deseable en la medida en que la pérdida social (daño esperado o $L$ ) sea menor a lo que las partes han debido invertir en prevención, sumando el valor real de reparación ${ }^{124}$. Cuando la variable radica sólo en el agente, la situación cambia, y este solo velará por su propia utilidad, siéndole irrelevante lo que haga la víctima.

La eficiencia social, según la teoría clásica, parte de la maximización de resultados, excluyendo, claro está, un resultado negativo en quien padece directamente el daño. Pero, en relación con daños intencionales, al estar la utilidad circunscrita al agente, difícilmente podría hablarse de beneficio social, a menos que, a través de políticas públicas específicas, se lograse redistribuir el excedente positivo del siniestro.

Lo mejor es ilustrar lo anterior a través de un ejemplo traído por la doctrina ${ }^{125}$. Supóngase que, existiendo niveles óptimos de prevención, tanto de la víctima como del agente, y que la ganancia es menor que el daño esperado, se deben suponer dos situaciones: responsabilidad o irresponsabilidad. Si el daño esperado $p D$ es 50 , el ocurrido $L$ es 40 , la ganancia esperada $p G$ es 35 , los costes de prevención son 10 en la víctima, $(A x)$ y 15 en el agente $(B y)$, en ausencia de responsabilidad, la utilidad neta en favor de este último es 20 $(p G-B y)$, mientras que la utilidad social es el $-40(p G-A y-B y-L)$, es decir, el daño efectivamente ocurrido; por lo cual es necesario disuadir su ocurrencia, a través de una $p D \geq L^{126}$. En efecto, la utilidad que el agente podría esperar es una pérdida de $-30 / /-20(p D / / L-p G-B y)$; y la utilidad social de la disuasión es la suma del coste privado de prevención, en nuestro

${ }^{123}$ Este es un claro ejemplo de pasividad eficiente de la víctima, cuya negligencia jamás será tenida en cuenta.

${ }^{124}$ En otras palabras, el test de eficiencia que debe superar un agente a la hora de emprender una actividad riesgosa, es preguntarse simplemente si la utilidad que le genera el daño (no simplemente la actividad) es mayor a lo que tendría que pagar por concepto de reparación, y hasta qué punto resulta conveniente invertir en prevención. En condiciones normales de mercado, y sin impunidad normativa, debería ser siempre más rentable invertir en prevención. Pero, cuando las condiciones se distorsionan y el mercado no responde a la expectativa de utilidad social, la posibilidad de impunidad resarcitoria se convierte en un activo contable seguido por muchos actores de dicho mercado; momento en el cual deben implementarse políticas públicas de corrección (disuasión).

${ }^{125}$ LANDES y POSNER, ob. cit., p. 154.

${ }^{126} \mathrm{pD}>\mathrm{L}$ en casos de especial relevancia de ciertas sectores, que justifiquen una mayor disuasión en el agente a la hora de asumir riesgos. 
ejemplo de $25\left(A y+L^{127}\right)$. Nótese que, contrario al modelo subjetivo de responsabilidad, en el cual lo relevante es la prevención privada, en el de dolo, lo mejor es la disuasión pública.

Si bien no se encuentra mayor dificultad en la importancia de hacer responsable al agente, surge el interrogante de cuál es el destino más eficiente de lo que este ha de pagar; si el Estado, en forma de multa, o es la víctima, como perjuicio. Nótese que aún no se habla de daños punitivos, sino tan solo de cómo hacer frente a conductas dolosamente arriesgadas. Así, lo más eficiente en caso de no haberse consolidado el perjuicio será el destino público de los recursos, pues, además de apalancar el coste de la disuasión (por ejemplo, de un adecuado desempeño del engranaje judicial), incentiva a la víctima a invertir en su propia prevención ${ }^{128}$.

Solución distinta debe darse en supuestos de utilidad esperada mayor al daño esperado $(G>D)$, en decir, en eventos donde el daño es socialmente beneficioso. El ejemplo traído por la doctrina es el de un robo por necesidad para evitar la muerte del propio agente del daño ${ }^{129}$. Dado que el coste de la reparación (v.gr. pagar la comida robada) es menor al del bien jurídico salvaguardado (la vida del agente), no será necesario que el Estado invierta en políticas externas de disuasión, ni que la víctima invierta en la prevención del siniestro. Por consiguiente, el Estado no requerirá fondos (obviando costes de transacción) ni ayudas privadas (prevención de víctimas potenciales); resultando eficiente una reparación directa a la víctima.

Otra variable a considerar es el daño real o $L$, variable a relacionar con el nivel de prevención eficiente que el agente debe emplear. En efecto, si la víctima es resarcida, no invertirá en prevención sencillamente porque no derivará mayor utilidad que el propio valor del daño, y por ende, este no se incrementará en dicho coste de prevención. Igualmente, si $G>D$, el nivel óptimo de prevención en el agente, es decir, $B y$, será el que disminuya el daño real $L^{130}$ y no así el daño esperado $D^{131}$.

En otras palabras, mientras que la ganancia esperada por el agente sea menor o igual al daño esperado, y debido a que la utilidad será puramente privada, un modelo eficiente de responsabilidad debe hacer énfasis en una polí-

${ }^{127}$ Para LANDES y PoSNER, a este valor se le debe sumar el valor real del daño $L$.

${ }^{128}$ LANDES y POSNER, ob. cit., p. 157.

${ }^{129}$ LANDES y POSNER, ob. cit., p. 155.

${ }^{130} P y(D-G)+B y=0$. El agente invertirá en prevención en la medida en que pueda reducir el daño real $L$. LANDES y POSNER, ob. cit., p. 156.

${ }^{131}$ Recuérdese que estamos en presencia de daños socialmente beneficiosos o lo que en el Derecho penal llamaríamos estado necesidad (donde el bien jurídico sacrificado es menor al protegido), y que por lo tanto, la disuasión no debe provenir de una daño esperado mayor (por lo general, según vimos párrafos anteriores, la disuasión en tratándose de $D \geq G$ consiste en la no inversión de los actores de la relación resarcitoria en prevención, porque $D$ disuade suficientemente a la víctima, siendo $\mathrm{D}>\mathrm{L}$ ). 
tica resarcitoria que incremente el valor del daño que este pueda esperar, disuadiendo su ocurrencia y evitando costes de prevención en las partes; evento en el que el coste asumido por el agente en virtud del daño tenga como destino apalancar de alguna manera el sistema disuasorio (haciendo más eficiente el aparato de justicia, etc.). Por su parte, cuando la ganancia esperada por el actor es mayor al daño esperado, es decir, cuando el daño es socialmente beneficioso, no conviene disuadir su ocurrencia de manera externa sino solo haciendo responsable al agente hasta la medida del daño real (que este intentará disminuir mas no necesariamente evitar). Nótese que en ambos supuestos, no sería eficiente que la víctima invirtiera en prevención al no estar en presencia de responsabilidad por culpa sino de daños intencionales ${ }^{132}$ (dolo).

Ahora bien, no siempre que la utilidad es mayor que el daño esperado $(G>D)$ puede hablarse de daño socialmente beneficioso. Como se ha explicado en este último supuesto, el ordenamiento no persigue una disuasión total; y la maximización de la utilidad se consigue a través de mecanismos tales como la responsabilidad del agente (cuya prevención llega hasta el nivel del daño efectivamente ocurrido), la no adopción de políticas externas disuasorias, y por ende, la pasividad de la víctima, la cual se verá reparada hasta el monto del daño real.

Pero la solución se tornará compleja si se analizan otras variables relevantes para la teoría económica, tales como valor y mercado. Siguiendo a Posner, por valor debe entenderse aquello que incrementa eficiencia al mercado $^{133}$. En consecuencia, un daño solo podrá ser socialmente beneficioso si se erige como un valor sustituto, es decir, si incrementa, en circunstancias específicas, la eficiencia de un mercado inoperable de manera transitoria. El ordenamiento jurídico no puede comparar valores subjetivos de agente y víctima más que en situaciones donde medien bienes jurídicos relevantes; pues, al final, la política pública de disuasión explicada en el evento de $G>D$ no es más que una ficción normativa de mercados sustitutos, como en el ejemplo de quien roba comida para sobrevivir.

Surge ahora el interrogante sobre dónde puede ubicarse la culpa grave (reckeless fault, o gross negligence ${ }^{134}$ ), es decir, aquellos supuestos en que el

${ }^{132}$ En el modelo de responsabilidad por culpa, el nivel óptimo de disuasión adjudica precaución tanto al agente como a la víctima (la víctima debe prevenir porque su culpa concurrente alivia o exonera de responsabilidad al agente, y este, por su parte, debe hacer lo propio al no poder esperar culpa de la víctima, en una relación de prevención recíproca); al tiempo que en presencia de dolo, y dado que no todas las situaciones dañinas son indeseables por el ordenamiento jurídico (daños socialmente beneficiosos), solo es apreciable un nivel eficiente, más no total de disuasión.

${ }^{133}$ LANDES y POSNER, ob. cit., p. 157.

${ }^{134}$ Lo que el Derecho continental de la responsabilidad civil identifica como culpa grave, lo diferencia el Derecho anglosajón y la Teoría Económica del Derecho entre recklessness y gross negligence. En efecto, el primer supuesto se asimila al dolo, mientras que el 
coste de prevención es positivo y sustancialmente inferior en comparación al daño esperado. Aquí el agente, si bien no desea el daño (no invierte en su ocurrencia), puede evitarlo a muy bajo coste. El análisis económico de la culpa cualificada la asimila al dolo, para efectos de prevención, y a ella debe aplicarse el análisis previo. Piénsese, por ejemplo, en la fábrica cuya contaminación puede superarse a través de tecnología económicamente adquirible.

\subsection{Tratamiento jurídico del daño intencional}

Corresponde ahora justificar la viabilidad económica de rubros no resarcitorios de daños en supuestos de siniestros intencionales (o equivalentes). No sobra recordar que por daños intencionales partimos de la conducta del agente que tiene por finalidad la ocurrencia de un resultado que este entiende (o asume a través de un juicio gravemente culposo o injustificado) ilegítimo ${ }^{135}$; y que la solución varía según la ganancia esperada por la relación no transaccional sea mayor o menor al daño esperado (daños socialmente beneficiosos o no), al daño real (nivel de prevención del agente y destino del rubro resarcitorio), así como a la connotación sustitutiva de la acción dañina en términos de incremento de valor de mercado, según se ha expuesto.

Debe aclararse que por tales deben entenderse no solo los denominados daños punitivos (punitive damages), sino aquellos cuya cuantificación demanda una valoración en equidad ${ }^{136}$; muchos de los cuales han sido asimilados, no sin gran debate jurídico, por nuestros tribunales y académicos.

Es claramente justificable el reconocimiento de este tipo de rubros del daño cuando la probabilidad de encontrar al agente y esperar de este reparación es remota por circunscribirse la acción dañina, por lo general, en mercados accesibles. Es decir, cuando el daño no tiene como causa la imposibi-

segundo constituye un caso límite de la culpa simple. Si bien en ambos tipos de culpa el coste de prevención es bajo en relación con el daño esperado, la diferencia radica en la notoriamente mayor incidencia que el primero tiene frente a la probabilidad de siniestro con relación al segundo. Es decir, cuando hablamos de gross negligence, un incremento en la prevención por parte del agente no varía sustancialmente la probabilidad del daño; mientras que al hablar de recklessness, la incidencia de la prevención en la probabilidad sí que es sensible.

${ }^{135}$ LANDES y POSNER, ob. cit., p. 161.

${ }^{136}$ Algún sector de la doctrina reconoce la diferencia entre resarcimiento y compensación como especies diferentes y complementarias del género reparación. Los daños punitivos son entendidos no solo como propiamente ejemplificantes, sino también como compensatorios, en la medida en que persiguen corregir la imposibilidad de cuantificación de daño. En efecto, es posible apreciar en la jurisprudencia norteamericana, criterios tan disímiles en la tasación del rubro punitivo, llegándose a veces al absurdo de multiplicar por números fijos el quantum del daño moral, etc. Más en MAdEN, M, Stuart y Boston, Gerald W, Law of environmental and toxic torts, cases, materials and problems. Ed. Thompson West: Cambridge, 2005 , pp. 240 y ss. 
lidad o la excesiva onerosidad de evitarlo (en otras palabras, cuando añade valor al mercado siendo la utilidad mayor que el daño esperado). Si el agente del daño lo comete para evitar asumir un coste socialmente eficiente (robar para evitar trabajar), se espera que cometa otras conductas tendentes a evitar ser encontrado. Una fórmula es multiplicar los daños causados por la probabilidad de éxito que pueda tener el agente (evitar la acción del Estado), inclusive adicionando otras variables como el riesgo generado por quienes podrían reincidir, los costes de administración de justicia, etc.

Debe analizarse la diferencia entre compensación y punibilidad en la responsabilidad: la compensación es la diferencia entre daño real $L$ y daño esperado $D$. El mecanismo compensatorio es eficiente en situaciones en las que el modelo no pretende desincentivar el desconocimiento del mercado en situaciones socialmente beneficiosas, en las cuales el agente se limite a la causación de un daño que se aproxime al daño real.

Esto se consigue a través de presunciones tales como pretasaciones de daños inmateriales, por ejemplo. Es decir, haciendo responsable al agente por encima del daño efectivamente causado, pero permitiéndole probar que su conducta solo se encaminó a salvaguardar un bien jurídico de igual o mayor valor (robar por comida) y hasta dicha medida (sin considerar el análisis de eximentes de responsabilidad, pues en este caso hablaríamos de una causa extraña, pero que desde una perspectiva económica no puede prescindirse de la responsabilidad dado que no se puede dejar a la víctima desprotegida), este desconocerá el mercado únicamente cuando los costes de transacción sean demasiado elevados, o lo que es igual, la utilidad sea mayor que el daño esperado.

Por el contrario, la punibilidad persigue el acatamiento exclusivo del mercado, en clara asunción de que cualquier desviación de este sería ineficiente (o inverificable). En este último evento, cuando las variables del mercado son de difícil aprehensión por parte del juez (es decir, la determinación de la diferencia entre daño esperado $D$ y daño real $L$ ), se reconocen daños punitivos como mecanismo compensatorio, ante la dificultad probatoria de las variables de eficiencia del acatamiento o desconocimiento de un mercado específico.

El reconocimiento de daños punitivos, mayor en situaciones de intencionalidad del agente que de simple culpa de este, se explica en que es más probable que su conducta dolosa se dé en condiciones no prohibitivas de mercado; lo cual implica, según hemos explicado, que la transacción resarcitoria no es socialmente beneficiosa (aunque no siempre se da así). Lo cierto es que el elemento propio del dolo, como suele ser la violencia, es más fácilmente aprehensible que la culpa, lo que conlleva a determinar un menor coste de error (verificar si la conducta podría ser excepcionalmente admitida y asumir que la tasación de perjuicios es mejor cerca a $L$ que a $D$ ) en relación con el coste de no disuasión.

No obstante, es posible derivar similar conclusión respecto de daños intencionales circunscritos a mercados prohibitivos, cuando quiera que el 
coste de oportunidad haya de ser tenido en cuenta a la hora de ponderar posibles excepciones a la prohibición. No se quiere defender con esto que, mediando coste de oportunidad en su obrar, el agente se limite a resarcir los daños efectivamente generados, pues la solución dependerá de si la utilidad es mayor que el daño esperado, así como de los mecanismos redistributivos de esta.

Piénsese en la fábrica que vierte desechos tóxicos a un río. En condiciones normales de mercado, le será más rentable a la fábrica filtrar sus residuos que indemnizar a toda una comunidad. Porque en la práctica ocurre que muy pocas víctimas acuden a la administración de justicia y, por algún motivo (ej. carga de la prueba), no a todas les es reconocido el pago perjuicios. El panorama descrito incentivaría al dueño de la fábrica a ahorrar en tecnología de filtrado, dado que la utilidad de contaminar (que no de la actividad de la fábrica) alcanza y sobra para asumir el coste judicial.

En actividades comerciales con algún impacto medioambiental, la mejor manera de obviar costes de verificación de elementos subjetivos (culpa) es la intervención administrativa a través de reglamentación. Dicho mecanismo es independiente, pero no por ello necesariamente ajeno, a la figura de la responsabilidad objetiva (strict liability). Por ejemplo, si bien puede hacerse responsable de daños resarcitorios al agente ante la simple ocurrencia del daño (strict liability), solo ante la ocurrencia de otras variables se le condenará al pago de daños punitivos; variables que podrían ser un umbral de daños, o una relación objetiva de comparación entre la utilidad percibida por la actividad comercial o industrial y otra cantidad fija, etc.

El ejemplo expuesto, al tratarse de una actividad reglada, obvia la dificultad de cuantificación de los costes de mercado, si bien alienta la solución de la punibilidad del daño en virtud de la intencionalidad del agente, los bajos costes del mercado (la rentabilidad de un negocio debe contabilizar egresos necesarios en prevención), la magnitud del siniestro (según la normativa contemple este criterio o no, etc.). Empero, no obstante, sería imaginable una prohibición in limine de semejante insensatez; así, a través de mecanismos punitivos, es posible plantear situaciones en las cuales las condiciones de mercado se agravan súbitamente y una prohibición tajante se tornaría ineficaz.

Otro ejemplo ilustrará mejor el punto. Considérese una industria de extracción de carbón que, para explotar nuevos terrenos adyacentes, precisa de autorización gubernamental. De repente (como en efecto ocurre en la actualidad), los precios internacionales del carbón se disparan y la obtención del permiso se torna nugatorio, dado que la instalación de la tecnología ecológica tardaría mucho tiempo (estudios y predicciones del mercado esperan una continuidad de la bonanza durante tiempo suficiente como para que, al menos, se alcance un punto de equilibrio). Está claro que tal proceder generará perjuicios en el aire que respiran aldeas vecinas, pero también que la utilidad sería muchas veces mayor que el trasladar a sus habitantes a 
otro lugar; así como que el incumplimiento de la reglamentación acarreará perjuicios.

Surge el interrogante sobre la eficacia de una prohibición absoluta de la industria energética por medio, por ejemplo, de daños punitivos exorbitantes ante la simple mediación de los elementos referenciados (intención, mercado a priori no prohibitivo, indeterminabilidad del perjuicio, etc.). La solución en este caso es, en el plano exclusivo de la responsabilidad civil, la implementación de daños punitivos no muy superiores al daño esperado $D$.

Ahora bien, es eficiente la punibilidad civil en relación con la culpa gra$v e$. Recordemos que la gradación de la culpa es fundamental a la hora de derivar soluciones. En efecto, todo depende de la incidencia que un incremento en el deber de cuidado tenga en la probabilidad de ocurrencia del siniestro.

La doctrina económica diferencia entre culpa grave (gross negligence) y culpa dolosa (recklessness). Mientras la alocación de recursos es eficiente en la culpa simple, por cuanto se espera que el coste de prevención óptimo se distribuya entre agente y víctima (ideal de prevención), no así en los supuestos de culpa cualificada. La teleología económica de la responsabilidad civil parte, según se ha explicado, de la eficiencia en la alocación de recursos; es decir, lo que las partes invierten en prevención ha de ser proporcional a la disminución en la probabilidad del daño; tal será el parámetro para cuantificar el daño punitivo según la culpa sea más o menos grave.

A mayor desproporción entre el coste de prevención y el daño esperado, en términos de probabilidad del siniestro, mayor deberá ser el incremento del rubro punitivo del daño como elemento correctivo del mercado. No se olvide que si bien el tratamiento que suele darle la legislación a la culpa grave como equiparable al dolo es insuficiente desde una perspectiva económica, dado que no toda culpa cualificada merece igual tratamiento; si bien, es claro que tratándose de gross negligence la alocación de recursos preventivos involucra en alguna medida a la víctima; en relación con la culpa catalogada como dolosa (recklessness) es ineficiente alocar recursos en persona distinta al agente, por estar este como verdadero control de la situación dañina.

A esta altura del estudio es posible concluir que la diferencia entre daño intencional y daño culposo, para la teoría económica del Derecho de daños, estriba en dos criterios claros: la alocación de recursos de prevención (de manera que el agente pueda eximir total o parcialmente su responsabilidad alegando culpa de la víctima ${ }^{137}$ ) y el reconocimiento de daños punitivos ${ }^{138}$.

${ }^{137}$ Desde una perspectiva civilista, tal solución no deja de tener complicaciones. Para el Derecho de daños continental, la culpa de la víctima opera como eximente de responsabilidad, inclusive en regímenes de responsabilidad objetiva, por cuanto afecta el nexo causal. Pero, para el análisis económico del Derecho, la culpa (no exclusiva) de la víctima solo es tenida en cuenta en la medida en que falte a un deber de cuidado previamente endilgado a ella por el modelo de daños; tratándose de dolo o culpa dolosa del agente, una alocación 


\subsection{El daño punitivo frente al error intencional}

Debe ahora explicarse la respuesta que da la teoría económica a supuestos de daños intencionales según la segunda acepción del vocablo, arriba estudiada; es decir, cuando el agente persigue el daño ante el hecho de que el coste de prevención es igual o mayor al del daño esperado, con una probabilidad de ocurrencia casi absoluta.

Si el agente obra sin error (aparente) en su apreciación de las circunstancias descritas, o sea, que el daño es inevitable ante la salvaguardia de un bien jurídico de igual o mayor importancia (v.gr. legítima defensa), desde una perspectiva económica no solo es inapropiado reconocer daños punitivos sino que operaría una exoneración total o parcial de responsabilidad, según el caso; por el contrario, si dicha apreciación es negligentemente valorada por el agente (es decir, el coste de prevención es menor que el daño esperado y ante una probabilidad igualmente alta), no solo es procedente endilgarle responsabilidad, sino también reconocer daños punitivos en la medida en que la negligencia sea cualificada (cuando la inversión en prevención es desproporcionadamente inferior con relación al daño esperado, según se ha visto).

El problema radica en la probabilidad de siniestro que el error incrementa $^{139}$, así como en el coste de evitarlo. Tal como se ha explicado, si el coste de prevención es desproporcionalmente bajo en relación con el daño esperado, y la probabilidad alta, estaremos en presencia de culpa intencional (recklessness) y la solución óptima será el reconocimiento de daños punitivos; en cambio, cuando el coste de prevención es más ajustado al daño esperado y la probabilidad se optimiza a través de la alocación de dicho coste tanto en el agente como en la víctima, se estará en presencia de culpa simple o negligencia (negligence).

Sin embargo, cuando el agente se presenta como el más idóneo para prevenir el daño, por contar con los medios y el control de la situación (lowercost avoider), independientemente del coste de prevención, la solución más eficiente deviene con la responsabilidad objetiva del ofensor; pero sin punibilidad civil cuando no concurren las variables arriba estudiadas (alta probabilidad de encontrar al agresor, de que este asuma el daño, así como costes de transacción prohibitivos).

eficiente de los costes de prevención obvia la conducta de la víctima; es decir, no opera como destructiva del nexo causal, sino que es valorada desde el mismo componente subjetivo de la responsabilidad.

${ }^{138}$ LANDES y PoSNER, ob. cit., p. 162.

${ }^{139}$ La alta probabilidad del daño es condición necesaria pero no suficiente de intención en el agente, para efectos económicos. 
Es decir, la responsabilidad objetiva no contradice necesariamente la condena en daños punitivos al agente. Los criterios para diferenciar el daño intencional del no intencional son la sanción económica (remedy) y la negligencia contributiva como mecanismo de defensa del agente. Que el error sea considerado como intencional no implica que la solución óptima sea el daño punitivo, ni tampoco que el modelo eficiente sea la responsabilidad objetiva.

Debe aclararse conceptos. El daño punitivo, como remedio de errores intencionales, depende no solo de la probabilidad de ocurrencia del daño, sino también de que el coste de prevención sea muy bajo respecto del daño esperado, y que la conducta del agente permita prever que evitará de cualquier modo asumir las consecuencias resarcitorias de su obrar. Noción diferente, aunque no excluyente, es la de alocación eficiente de recursos de prevención; si la prevención en la víctima se erige como prohibitiva, se estará en presencia de responsabilidad objetiva, de lo contrario, regirá el modelo de culpa simple o contributiva. Lo que sucede es que la responsabilidad objetiva convierte en intencional determinados niveles no intencionales de culpa, como el descuido grave (careles negligence o gross fault); aunque el remedio no contemple daños punitivos.

El ejemplo que propone la doctrina para comprender mejor este intrincado juego de palabras es el atentado a la honra de las personas (defamation). Un periódico publica una historia injuriosa sobre un sujeto imaginario cuyo nombre es corriente en la sociedad destinataria de la información. Un sujeto con el mismo nombre del personaje inventado demanda al periódico alegando que vecinos suyos pensaron que se trataba de él. La justicia condenó al medio informativo al pago de perjuicios resarcitorios y punitivos. El periódico alega, en su defensa, que se trató de un error insuperable que no ameritaba condena alguna, y que, en el peor de los casos, no se justificaba el reconocimiento de daños punitivos.

El caso plantea un ejemplo de culpa intencional (recklessness) y de responsabilidad objetiva (strict liability). En efecto, dado que la posibilidad que tiene la víctima era remota o en exceso onerosa (esconderse durante algún tiempo; comprar todo el tiraje del día de la publicación, etc.), es económicamente predicable que el agente era el actor ideal de prevención. Así mismo, es claro que el coste de prevención es bajo en relación con el daño esperado (advertir al comienzo de la historia que esta era ficticia); y que la probabilidad de siniestro es casi absoluta (la probabilidad de que una persona se vea identificada con la historia es alta en cuanto que el volumen de ejemplares y el porcentaje de individuos en la comunidad destinataria también es alta).

La alta probabilidad del daño, unida al bajo coste de prevención, describe el caso como un claro ejemplo de culpa intencional, y por ello justifica la condena al pago de perjuicios. Por su parte, el coste prohibitivo de prevención en la víctima sugiere el modelo de la responsabilidad objetiva (que solo el agente adopte medidas de prevención). No obstante, no se configuran los 
demás requisitos económicos del daño punitivo, por cuanto el ofensor es fácilmente identificable, es predecible que este asuma el resultado dañino, y el coste de sustitución de mercado es también prohibitivo (el periódico no podía conciliar con alguien que no existe).

La categorización de la conducta como intencional cobra relevancia en la determinación del nivel de prevención esperada en el agente. Tratándose de una responsabilidad equivalente, o conversión (el agente paga solo y nada más que el daño), propio del modelo de culpa simple (contributory negligen$c e$ ), el agente invertirá en prevención en la medida en que pueda complementar la prevención de la víctima, y solo hasta el valor del daño efectivo. Pero, tal y como se explicó en párrafos anteriores, la variable a considerar en este caso es el daño esperado, pues lo que resulta eficiente es que el agente se aproxime al nivel óptimo de prevención. En nuestro ejemplo del periódico, el carácter intencional del error justifica, no la admisibilidad del daño punitivo, sino el incremento del daño esperado como variable de comparación que tenga el agente al momento de invertir en prevención.

\subsection{Procedibilidad de la acción}

Bajo el modelo de culpa simple, suele exigirse a la víctima probar que la conducta negligente del actor carece de justificación (reasonableness). Ello no implica, claro está, que pruebe la ausencia de causa extraña; lo cual sería excesivo y conllevaría por defecto a la casi siempre exoneración del agente. Por el contrario, la acreditación del elemento subjetivo por la víctima incluye, en un estadio de procedibilidad de la acción, su diligencia; es decir, que el ofensor no pueda alegar concurrencia de culpa o contributory negligence. Recuérdese que, desde una perspectiva de law and economics, la prevención eficiente se logra a través de una alocación equilibrada de costes entre las partes; y que tal requisito de procedibilidad es independiente de la posterior valoración que el juez realice del acervo probatorio aportado ${ }^{140}$.

Ahora bien, la prima facie del daño intencional depende de la acreditación de mínimos elementos condenatorios, tales como el incremento de la probabilidad, un coste de prevención negativo (que el agente ha invertido en la generación del siniestro) o desproporcionalmente inferior respecto del daño esperado. La irrazonabilidad que debe desvirtuar el demandado (presunción) es diferente en esencia a la del régimen de culpa simple; nótese que lo que espera el agente no es la mera condena en perjuicios al ofensor, sino el reconocimiento de daños punitivos, de ahí que incremente su esfuerzo probatorio ${ }^{141}$.

${ }^{140}$ LANDES y Posner, ob. cit., p. 167.

${ }^{141}$ Mientras que en el modelo de contributory negligence la víctima acredita culpa irrazonable del agente a través de su propia diligencia; cuando alega daño intencional debe aprehender variables cuantificables tales como una mayor probabilidad del daño, el bajo o negativo coste de prevención, etc. Igualmente, superada esta etapa procesal, se incrementa 
Corresponde ahora analizar la prima facie de algunos de los típicos casos de daños intencionales, al menos aquellos en los cuales la doctrina admite, por unanimidad, el reconocimiento de daños punitivos: externalidad (tort of nuisance), robo con agresión física (battery); asalto (assault) y transgresión de propiedad privada (trespass).

Los daños físicos a las personas suelen dividirse en battery y assault. Battery es definido como «unlawful beating or wounding of a person or mere touching in a hostile or offensive manner ${ }^{142}$ ». Pero ¿hasta qué punto es eficiente en causar todos los «contactos físicos hostiles o no consentidos» como típicos? Para efectos, la acción (independientemente del resultado del proceso) es económicamente eficiente la elaboración prima facie de las variables descritas: la conducta ha incrementado la probabilidad de un daño (deseado o no), el coste de prevención en el agente es bajo o negativo, y prohibitivo en la víctima (depende de si el modelo de responsabilidad adoptado es culpa simple o responsabilidad objetiva).

Apréciese que otras variables no son tenidas en cuenta. En consecuencia, la concesión de daños punitivos depende tanto de la existencia de un mercado sustituto eficiente, como de la relación utilidad-daño (si la utilidad es menor); es decir, de si el daño es socialmente beneficioso. La intencionalidad, se repite, no depende del deseo de obtención del daño, y puede inferirse del simple error culposo (recklessness).

Pero, no siempre que hay daño es económicamente eficiente endilgar responsabilidad y, en consecuencia, el razonamiento de prevención explicado para el tort of battery es improcedente. Tal es el caso del assault (amenaza o asalto), así no vaya acompañado de una agresión física. En efecto, debe recordarse al lector cómo prevención y disuasión son finalidades económicas independientes del derecho de daños; mientras la prevención agrava el resultado dañino en lo que la doctrina reconoce como daño esperado, partiendo del reconocimiento social implícito de perjuicios excepcionalmente beneficiosos, la disuasión demanda una política económica externa o no resarcitoria como respuesta a la conducta del agente.

Dicha independencia explica por qué es frecuente encontrar decisiones judiciales donde los daños punitivos otorgados a la víctima superan, en múltiples veces, los daños resarcitorios. Igualmente, existen decisiones que cuantifican este rubro correctivo, a través de daños compensatorios, como suele ser el moral. Piénsese en la variedad del assault denominada

el coste de defensa del agente bajo el modelo de intencionalidad, dado que la razonabilidad de su conducta no depende de la conducta de la víctima, sino de factores externos tales como el carácter prohibitivo del mercado principal.

${ }^{142}$ Collins Dictionary \& Thesaurus. Tercera edición, Reino Unido: 2005. 
tort of intentional infliction or emotional distress (daño al equilibrio emocional).

Resulta evidente, además, que no toda amenaza de una consecuencia dañina merece una política de disuasión, dado que en la práctica existen numerosas situaciones de amenaza legítima (la propia descripción de norma como silogismo jurídico). Así como no todo daño debe ser reparado (incluso bajo el modelo de strict liability existen causales externas de exoneración), no siempre que el daño es intencional se deben reconocer daños punitivos. Cuando el coste de establecer la necesidad de disuasión es muy alto (si el nexo causal es incierto, o si las condiciones de mercado son prohibitivas, etc.), lo eficiente por defecto es la prevención. El equilibrio del mercado no se da, entonces, vía daños punitivos, sino mediante daños compensatorios correctivos (algo corriente entre nuestros tribunales a la hora de cuantificar el daño moral u otros rubros no compensatorios del daño con base en la equidad, cuando, por ejemplo, los daños personales no devienen tan claros).

Por último, conviene analizar el daño denominado trespass to land. Este es un claro ejemplo de la diferencia entre prevención y disuasión que se concretiza o materializa en la distinción entre strict liability e intencional tort. Como no toda invasión a la propiedad privada es socialmente indeseada, el daño punitivo se presenta como una reacción excesiva al problema.

Sin embargo, es conveniente que el ordenamiento canalice en el mercado el uso de ajeno de la propiedad privada, por cuanto es pilar del liberalismo la defensa del coste de oportunidad implícito en el derecho real de propiedad, así como la alocación de prevención en la víctima es por definición ineficiente (quien realmente puede, a un menor coste, evitar el daño, es el propio agente); la solución tradicional que da el Derecho de la responsabilidad es el modelo de la strict liability, y medidas correctivas externas solo cuando se presenten las demás variables ya explicadas, como el deseo de producir el resultado dañino (intención bajo la tercera acepción del vocablo), una utilidad desproporcionadamente inferior al daño esperado, un coste de prevención irrisorio y un incremento significativo del riesgo, etc.

\subsection{Causales de exoneración en el daño intencional}

Se ha explicado cómo el reconocimiento de daños punitivos o ejemplificantes carece de justificación económica en algunos eventos de perjuicio intencional. Si en los casos de culpa grave (recklessness) o conciencia y deseo del resultado dañino (deliberate wrongdoing, tercera acepción de intencional), el ordenamiento asume, como implícitamente aceptables, algunas conductas socialmente beneficiosas a través de modelos de responsabilidad compensatoria (objetiva o subjetiva según su eficiencia en la alocación de recursos de prevención); con mucha mayor razón tratándose de culpa 
intencional $^{143}$. Y es que la prima facie de daños intencionales es mucho más flexible que la posterior valoración probatoria de la eficiencia económica de los comportamientos dañinos. El Common Law contradice por definición la aplicación indeterminada de supuestos normativos. Las reglas elaboradas por la jurisprudencia admiten en el juez un análisis contextual de la viabilidad económica de ciertas conductas ${ }^{144}$. Esto es importante a la hora de entender los mecanismos de defensa del demandado respecto o frente a daños punitivos.

La defensa del demandado debe partir de la consideración de la conducta como no susceptible de prohibición in limine por parte del ordenamiento jurídico. En efecto, como argumentos comunes a los supuestos típicos de consentimiento (consent), defensa propia (self defense) y defensa de la propiedad (defense to property), se encuentran el carácter prohibitivo del mercado específico; la utilidad mayor que el daño esperado $(G>D$; o que el daño es eficiente o value-maximizing); los mecanismos redistributivos de dicha utilidad (que esta tiene una connotación pública); que la mayor probabilidad responde a la escala de la propia actividad, o que el daño es, por su propia naturaleza, inevitable -primera acepción de intencional- (scale of activity); que los daños ejemplarizantes no tendrían por efecto desincentivar el mercado privado de prevención; y que las causales específicas operan dentro de los límites reglados de la razonabilidad.

El consentimiento (consent), como causal tipificada de exoneración, transforma la coerción en intercambio voluntario; finalidad última del derecho como prevención, desde una perspectiva económica, pero justificado en su aplicación como norma de corrección ${ }^{145}$ (tort law), tal y como se anticipó en la introducción de este estudio ${ }^{146}$.

${ }^{143}$ Las estadísticas recogidas por LANDES y PoSNER, ob. cit., p. 184, hasta el año de 1987, muestran cómo en el $72 \%$ de los casos, típicamente admitidos como deliberate wrongdoing (fraud, retaliatory discharge, libel, battery, etc.), se reconocen daños punitivos, contra apenas un $23 \%$ respecto de daños, apriorísticamente admitidos como culposos (negligence). Igualmente, mientras el número de apelaciones es de apenas un $15 \%$ en el primer supuesto, en el segundo llegan al 75\%.

${ }^{144}$ LANDES y POSNER, ob. cit., p. 184. La regla de daños punitivos descrita en relación con la deliberate wrongdoings dice «where the defendant's wrongdoing has been intentional and deliberate, and has the character of outrage frequently associated with crime, all but a few courts have permitted the jury to award in the tort action punitive or exemplary damages»; para la culpa cualificada, «such a conscious and deliberate disregard of the interests of others that the conduct may be called wilful or wanton... -reckless-as proceeding with knowledge that the harm is substantially certain to occur, and the mere unreasonable risk of harm to another involved in ordinary negligence». Ahora bien, los daños punitivos no son automáticos porque «it is not so much the particular tort committed as the defendant's motives and conduct in committing it will be important as the basis of the award».

${ }^{145}$ LANDES y POSNER, ob. cit., p. 171.

${ }^{146}$ El Derecho de daños es la respuesta estandarizada al carácter prohibitivo de las relaciones resarcitorias no transaccionales. En efecto, ante un daño, que se presume resulta de un comportamiento desviado de las condiciones de un mercado eficiente, el Derecho entien- 
El principal problema relacionado con el consentimiento versa sobre su errónea percepción por parte del agente (misleading impression of consent). Las variables a considerar, dadas por el análisis económico del Derecho, son más que predecibles: la eficiente alocación de recursos de prevención en el error, así como las condiciones específicas del mercado. En efecto, la parte cuyo cost of avoidance, según las condiciones del mercado, sea más bajo, asumirá las consecuencias económicas del consentimiento erróneo. Contrario a la solución civilista de este vicio relativo, la eficiencia económica de la relación resarcitoria no endilga presunción alguna; tanto la víctima como el agente deberán probar que las variables antedichas no los perjudican ${ }^{147}$.

La segunda causal tipificada es la legítima defensa (self-defense). Su función es preventiva, más que disuasoria. El derecho que tiene la víctima a defenderse de la agresión (evento que la ubica a su vez como demandado por haberse anticipado al resultado dañino) aumenta los costes del daño evitado, afectando la expectativa de utilidad del ofensor y, por ende, disminuyendo la probabilidad $^{148}$.

Pero el derecho de defensa no es ilimitado, sino que debe ser ejercido dentro de límites precisos de la razonabilidad (reasonableness). La razonabilidad se refiere tanto a la apreciación de la agresión como a su respuesta. Lo primero se refiere a posibles errores del agresor en, por ejemplo, la legitimación de su conducta o el deseo del resultado dañino. El segundo habla de que la respuesta debe ser proporcional y solo justificable en relación con amenazas que atenten contra la integridad personal de quien la ejerce; y siempre y cuando sea el mecanismo más eficiente de respuesta. Y es que la víctima debe ser consciente de que el bien jurídico que intenta salvaguardar es mayor que el vulnerado por el agresor.

Por eso se dice que esta causal de exoneración versa, no sobre la responsabilidad compensatoria sino respecto del reconocimiento de daños punitivos; como «esfuerzo por minimizar los costes de prevención de las partes ${ }^{149}$ »

de que su corrección difícilmente podrá darse en condiciones privadas de negociación; con independencia de los mecanismos alternativos de resolución de controversias.

${ }^{147} \mathrm{El}$ ejemplo que da lo doctrina es el de la unforseen emergency en procedimientos quirúrgicos; como el caso de un paciente en cuya intervención debió ser operado de algo distinto a aquello para lo cual había emitido expresamente su consentimiento. El galeno debió asumir su consentimiento como implícito para poder salvarle la vida. Ver LANDES y POSNER, ob. cit., p. 172.

${ }^{148} G^{a}=p(x, y)(G-D)-B(y)>0$, donde $\mathrm{G}^{\mathrm{a}}$, utilidad desencadenante del daño, es mayor a cero, y $\mathrm{D}$ es el daño resultante de ambas agresiones (el que origina la self-defense y el que es que ésta desencadena); $B(y)$ incluirá a su vez, el coste de prevención, por lo general negativo, no solo del agente (quien intentará producir el daño), sino también de la víctima, la cual, al anticiparse al daño, invertirá recursos para generar un daño en su ofensor. Ver en LANDES y POSNER, ob. cit., p. 173.

${ }^{149}$ LANDES y POSNER, ob. cit., p. 174. 
(damage limitation). No puede perderse de vista que el agresor que, pese al mayor coste de su conducta, la ejecuta, es difícilmente disuasible; el objetivo de la self-defense no es otro que el de subordinar la disuasión a la limitación del daño. La valoración del error en la defensa debe basarse, entonces, en las mismas variables estudiadas respecto del consent: alocación eficiente de prevención y otras alternativas no prohibitivas del mercado. Es decir, un modelo de culpa simple (negligence).

El tercero y último medio de exoneración reglado por el Common Law es la defensa a la propiedad (defense or property). Esta causal incluye los eventos de atentado a la integridad personal del agresor potencial (use offorce), por parte de la víctima, para defender su propiedad; el desconocimiento de la propiedad ajena para proteger la propia; y el de defensa de la propiedad de un tercero.

El primer supuesto (agresión de la víctima al agente para proteger su propiedad) suele estar delimitado estatutariamente en la integridad personal del agresor (muerte o lesiones graves). Este condicionamiento de eficacia de la exoneración se justifica teóricamente en la asunción del mayor valor de la vida que el de la propiedad (damage-limitation theory); y en la improcedencia de una finalidad disuasoria de la responsabilidad, según se explicó en la self-defense.

No obstante, si bien el Common Law no es indiferente a la razonabilidad de esta causal de exoneración, también contempla, como criterio de interpretación, el de si el medio de defensa es el menos prohibitivo en la relación coste-probabilidad de daño. No puede olvidarse que el objetivo económico de las causales de exoneración (self-help remedies) es la prevención (no la retaliación o venganza).

El ejemplo clásico recogido por la doctrina es el del arma con dispositivo de disparo automático ${ }^{150}$ (spring guns). Su coste es, evidentemente, menor que el de otros mecanismos de prevención (v.gr., vigilancia privada), y la probabilidad de error disminuye significativamente por medio de una advertencia visible a potenciales intrusos no ilegítimos; conciliando así los postulados de la regla de damage-limitation (que la vida vale más que la propiedad como premisa de razonabilidad de la defensa), con la eficiente alocación de recursos de prevención perseguida por el análisis económico del tort law (la advertencia de las consecuencias de la agresión, traslada la prevención del error en el agente: si este invade propiedad ajena será a su propio riesgo).

El segundo supuesto (desconocimiento de la propiedad ajena para salvaguardar la propia) hace referencia a las reglas de trespass of necessity o private necessity ${ }^{151}$. Por simple lógica, la necesidad de una de las partes confiere a la otra tal poder de negociación (asumido por la última como cost of

${ }^{150}$ LANDES y PoSNER, ob. cit., p. 174.

${ }^{151}$ LANDES y PoSNER, ob. cit., p. 177. 
opportunity), que torna prohibitivo cualquier acuerdo privado (bilateral monopoly). Lo anterior explica que, de aplicarse el modelo de la culpa simple (negligence), el agente de un daño por necesidad debería ser exonerado completamente, si ha procedido, con razonable consciencia, de que su propiedad protegida vale más que la sacrificada (daño esperado es menor que el daño real o $L>D$ ).

No obstante, el Common Law suele aplicar la regla de la responsabilidad objetiva en eventos de necesidad, aceptando la causal en estudio con el único efecto de no reconocer daños punitivos. Y es que el modelo de la strict liability también se justifica en lo esporádico del daño (alocar recursos de prevención permanentes en relación con riesgos con muy baja probabilidad sería ineficiente); y en que incentiva cambios de comportamiento, a largo plazo, en los potenciales agentes, de manera tal que el sacrificio de la propiedad ajena sea verdaderamente excepcional ${ }^{152}$.

Solución distinta se da en el tercer y último supuesto de la causal defense to property (defensa de un bien público en sacrificio de un derecho de propiedad ajeno). Su objetivo económico no es otro que el de incentivar la defensa colectiva de bienes de interés general, a través de la externalización del daño privado; típico evento de public necessity.

Para ello, y a pesar de tratarse de un daño esporádico (que ameritaría, según el argumento esgrimido para el supuesto segundo de esta causal, arriba estudiado), el modelo de responsabilidad idóneo en relación con el ejercicio erróneo de la defensa, es la culpa simple (negligence). Es decir, esta causal es eximente, no solo de daños sancionatorios, sino también de responsabilidad compensatoria; porque, además de ser prohibitiva la internalización de beneficios, debido al alto número de individuos con quienes podría el agente negociar, debe ser política pública el incentivo en la defensa activa de derechos e intereses colectivos ${ }^{153}$.

\subsection{Cómo medir eficientemente el daño punitivo}

La teoría de la Internalización racional de la norma, planteada por Coo$\operatorname{ter}^{154}$ (Rational self-monitoring theory) explica la importancia de aumentar

${ }^{152}$ La irresponsabilidad, por su parte, desincentivaría la solidaridad pública, incrementando la inversión en prevención contra daños remotos, de manera completamente ineficiente.

${ }^{153}$ Recuérdese cómo el argumento contrario justifica el reconocimiento de daños punitivos, en relación con derechos e intereses colectivos. En efecto, cuando el agente pretende obtener beneficios privados, en sacrificio de su propia colectividad, el mecanismo punitivo de la responsabilidad civil, en su función disuasoria, no es más que la internalización, también privada, de los dichos daños colectivos, más allá de las dificultades teóricas y prácticas en su cuantificación.

${ }^{154}$ COOTER, «Punitive damages for deterrence: when and how much». Alabama Law Review, Vol. 40, Spring 1989, No. 3, p. 73, en <http://works.bepress.com/cgi/viewcontent.cgi?article= 1097\&context=robert_cooter $>$. 
el daño compensatorio, cuando el objetivo disuasorio de la norma falla, debido a su racional desconocimiento por parte del agente, quien pretende derivar un beneficio privado de su conducta dañina. En otras palabras, el daño punitivo tiene como función corregir la ineficiencia de la norma respecto de daños intencionales ${ }^{155}$.

Pero, una incorrecta valoración del mínimo correctivo del daño, traería como consecuencias, bien una disuasión inadecuada aunque excesivamente costosa en términos sociales (enriqueciendo a unos pocos pero sin alterar la conducta del agente), cuando es insuficiente; o distorsionando la naturaleza de la responsabilidad, irrogándole funciones administrativas de índole policivo a la administración de justicia, así como atentando contra el normal desarrollo de mercados económicamente productivos, cuando es excesiva. Esto explica la generalizada reticencia hacia este tipo de daños, no solo por parte de ordenamientos jurídicos de corte civilista, sino por el propio Derecho estatutario elaborado a la sombra del Common Law ${ }^{156}$.

Y es que la jurisprudencia del Common Law, así como el Derecho regulado $^{157}$, poco han ayudado a trazar, de manera consistente y pacífica, las pautas necesarias para que estos daños coincidan con su finalidad económica.

${ }^{155}$ COOTER, R, «Punitive Damages...» ob. cit., p. 74: «Optimal deterrence requires increasing compensatory damages by the reciprocal of the enforcement error».

${ }^{156}$ Un ejemplo es la normativa antitrust de los EE.UU., Clayton Act, que en su reforma de 1994 prevé diferentes limitaciones al poder de la Corte a la hora de imponer sanciones civiles a los directores de empresas implicadas en prácticas desleales, dominantes o anticompetitivas. Así, en su apartado 7A § 18a. (g), sobre penas civiles, cumplimiento y facultad de la Corte, reza: «Any person, or any officer, director, or partner there of, who fails to comply with any provision of this section shall be liable to the United States for a civil penalty of not more than $\$ 10,000$ for each day during which such person is in violation of this section. Such penalty may be recovered in a civil action brought by the United States». Y, más específicamente, en su apartado 14: «whenever a corporation shall violate any of the penal provisions of the antitrust laws, such violation shall be deemed to be also that of the individual directors, officers, or agents of such corporation who shall have authorized, ordered, or done any of the acts constituting in whole or in part such violation, and such violation shall be deemed a misdemeanour, and upon conviction therefore of any such director, officer, or agent he shall be punished by a fine of not exceeding $\$ 5,000$ or by imprisonment for not exceeding one year, or by both, in the discretion of the court». Ver en <http:// siteresources.worldbank.org/INTCOMPLEGALDB/Resources/ClaytonAct.pdf>, $§ 14$ Clayton Act, 15 U.S.C. § 24., 5 de Octubre de 2008.

${ }^{157}$ Por ejemplo, el Código Civil de California, en su modificación de 1998, No. 3294: únicamente se limita a describir la conducta dañina en que es posible reconocer daños punitivo: «(a) In an action for the breach of an obligation not arising from contract, where it is proven by clear and convincing evidence that the defendant has been guilty of oppression, fraud, or malice, the plaintiff, in addition to the actual damages, may recover damages for the sake of example and by way of punishing the defendant». En la letra $b$ cualifica la conducta del empleador por daños de sus dependientes, para efectos de daños punitivos; y en la $g$ individualiza conceptualmente esta modalidad de daño en caso de muerte de la víctima. Ver en <http://law.justia.com/california/codes/civ/3294-3296.html>, 10 de Octubre de 2008. 
Antes de continuar, es necesario recordar la diferencia entre prevención y disuasión o, de manera más técnica, entre liability right y prohibition. En el primer caso, la finalidad del modelo no es otra que la eficiente alocación de recursos entre las partes, de manera que se internalicen proporcionalmente las consecuencias económicas del siniestro. No es de extrañar que esto se consiga a través de lo que la doctrina anglosajona denomina como perfect compensation, donde el agente es libre de valorar sus propios riesgos en la medida en que puede asumir el resultado.

Cuando la condena excede a los daños reales $(D>L)$, o cuando el daño es intangible ${ }^{158}$, este rubro extra compensatorio también tiene una finalidad correctiva, aunque no disuasoria, de los errores de la internalización, tal y como se estudió en los daños prima facie intencionales, pero económicamente culposos. El método del riesgo equivalente ${ }^{159}$ (risk-equivalent method) proporciona un criterio consistente de tasación de esta acepción de daños punitivos $^{160}$.

Solución distinta para comportamientos prohibidos, donde la reparación de la víctima pasa a un segundo plano respecto de la finalidad disuasoria del modelo. Aquí los daños punitivos corrigen la prohibición, por lo cual tienen como primera variable de tasación la utilidad del agente, más que el perjuicio causado. Debe tenerse en cuenta que, cuando el modelo compensatorio falla, por ejemplo, por ser incierta la intencionalidad del agente, sobre todo en regímenes de responsabilidad objetiva, la cuantificación del rubro punitivo deberá también acudir al perjuicio real como criterio adicional a la utilidad.

${ }^{158}$ El origen de los daños punitivos se encuentra en los derechos a la honra y buena imagen. COOTER nos ejemplifica rubros del daño inmaterial difícilmente individualizables por la jurisprudencia, ante la insolvencia probatoria, y cuyo remedio usual preventivo es el incremento punitivo de los perjuicios resarcitorios (filling the gap): «Sometimes the legal methodology for computing compensatory damages omits categories of harm. To illustrate, the law may fail to compensate fully for consequential damages, remote damages, economic losses, exposure to risk, emotional distress, or pain and suffering» (COOTER, R., «Punitive Damages...», ob. cit., p. 85). Es tal el caso Alcorn v. Mitchel, analizado por PosNER, en el que, en 1872, se reconocen US\$ 1000 por concepto de daños punitivos (frente a tan solo US\$ 20 por daños compensatorios), a la víctima de una agresión verbal en un lugar público (LANDES y POSNER, ob. cit., p. 161).

${ }^{159} L=X / p$, donde $L$ es el daño a un bien prohibitivamente sustituible (tanto material como inmaterial; v.gr. un cuadro original, o el dolor por la muerte de un ser querido), un daño intencional atenuado (v.gr. por un error en una causal de exoneración), o un daño no intencional pero con otros errores no transaccionales (bajo el modelo de la negligence); $X$ es el nivel adecuado de prevención por cada unidad de riesgo $p$, según una norma social o legal, siendo $X>p L$. Ver más en CoOTER, Robert, «Punitive Damages...», ob. cit., p. 84.

${ }^{160}$ Este método puede ser usado para corregir las inconsistencias de jueces del sistema continental a la hora de tasar perjuicios inmateriales. Son frecuentes las discrepancias jurisprudenciales en la creación de reglas (o en el seguimiento de pautas legales) que valoran artificialmente y con poco rigor científico, estos rubros del daño; a través de los cuales, valga la pena mencionarlo, se corrigen ciertas conductas socialmente reprochables. 
En relación con daños intencionales, la doctrina ofrece criterios auxiliares, la mayoría de las veces no seguidos por las cortes ${ }^{161}$. Cooter, por ejemplo, diferencia tres situaciones causantes de daños intencionales, cada una con reglas propias de tasación.

Una primera causa de intencionalidad en el agente es ocasionada por la incorrecta valoración de daños compensatorios, debido, principalmente, a la baja probabilidad de ejecución de la norma, es decir, que no siempre el causante del daño es encontrado o paga efectivamente por su conducta (errors in enforcing compensatory damages).

$\mathrm{Tal}$ es la regla de la reciprocidad (rule of reciprocral ${ }^{162}$ ), formulada $\mathrm{L}=$ $L+\mathrm{PD}(\mathrm{L}=\mathrm{D})$, donde L (liability) es el daño total que debe reconocer la

${ }^{161}$ El modelo de juicio-jurado propio del Common Law dificulta la elaboración o seguimiento de reglas estándares de disuasión respecto de daños intencionales. En efecto, el papel del juez es ilustrar al jurado acerca de los requerimientos mínimos de reconocimiento y tasación de daños punitivos, aunque según consta en las estadísticas, la probabilidad de un individuo de repetir su rol como jurado son mínimamente prohibitivas. Tal incertidumbre tiene un resultado nefasto para la finalidad económica de la responsabilidad, como puede verse en la teoría de la incertidumbre formulada por CALFEE y CRASWELL, analizada en este estudio, y mejor entendida según el modelo expuesto por COOTER en la Teoría de las Normas Sociales. Corolario de lo anterior, no existen en el Common Law criterios o reglas ciertas y constantemente seguidas para este tipo de daños. Ver más en COOTER, Robert, «Punitive Damages...», ob. cit., p. 85.

${ }^{162}$ Una más profusa explicación de la regla de la reciprocidad puede verse en COOTER, Robert, y Ulen, Thomas. Derecho y economía. Ed. Fondo de Cultura Económica. México: 1997, pp. 442-446. Se advierte al lector que las siglas han sido traducidas a las utilizadas a lo largo del presente trabajo. Ha de entenderse que cada autor maneja sus propias siglas; y que el siguiente análisis es meramente económico. Supóngase un agente racionalmente egoísta, interesado únicamente en minimizar su coste de prevención en relación con el daño esperado: $X^{\prime}=\mathrm{cx}+\mathrm{p}(\mathrm{x}) \mathrm{D}\left(K^{\prime}\right.$ es el coste minimizado de precaución; $p$ es la probabilidad de causación del daño; $D$ es el daño esperado; $x$ el nivel de prevención efectivamente asumido; $c$ es el coste de dicha unidad de prevención $x$ ). Pero a dicho agente solo le interesa el valor del daño efectivamente reconocido en juicio, es decir, el daño subjetivamente esperado $\mathrm{X}^{\wedge}$, en lugar del daño esperado por la víctima $\mathrm{D}$, asumiendo un coste de prevención que minimiza la probabilidad del daño efectivamente reconocido en juicio, $\mathrm{L}: X^{\wedge}=\mathrm{cx}+\mathrm{p}(\mathrm{x}) \mathrm{L}$. Para evitar ser condenado en daños punitivos, la responsabilidad del agente debe asumir el error de ejecución de la norma, $e$, de manera que se actualice el daño efectivamente reconocido, resultado de tal error: $e \rightarrow \mathrm{L}=\mathrm{D} e . \mathrm{X}^{\prime}=\mathrm{cx}+\mathrm{p}(\mathrm{x}) \mathrm{D} \rightarrow \mathrm{X}^{\prime}=\mathrm{cx}+\mathrm{p}(\mathrm{x}) \mathrm{D} e$ (donde $e$ representa la externalización del coste social que incentiva al agente a asumir una prevención ineficiente). Para que el agente internalice el coste social (error en la ejecución de la norma), los daños compensatorios deben ser aumentados a través de una sanción. Así, de admitirse los daños punitivos, el multiple punitive deberá multiplicarse por los daños compensatorios (daño esperado), actualizados por el error: $e \rightarrow \mathrm{L}=\mathrm{D} e m \rightarrow \mathrm{X}^{\prime}=\mathrm{wx}+\mathrm{p}(\mathrm{x})$ A $e m$. De esta manera, el coste marginal de prevención, $w$ (o sea, el asumido por el agente de manera egoísta), iguala a la reducción marginal de la probabilidad del daño, $p$, multiplicado el daño esperado, ya valorado el error: $\mathrm{A} e \rightarrow 0=\mathrm{c}+\mathrm{p}(\mathrm{x}) \mathrm{D} e$. Adecuando la ecuación, $e$ es percibido por el agente como la unidad de prevención asumida dividido por la reducción de daño compensatorio por cada unidad de prevención adicional: $e=\mathrm{c} /[-\mathrm{p}(\mathrm{x}) \mathrm{D}]$. Entonces, 
corte para corregir el error de ejecución, $L$ (loss) es el daño efectivamente reconocido según la probabilidad de error $(L=\mathrm{D}(\mathrm{e})$, siendo $\mathrm{D}$ el daño esperado -expected damage-, y $e$ el margen de error), y $\mathrm{PD}$ es el daño punitivo (punitive damage), donde $\mathrm{PD}=\mathrm{D}-L$.

Un ejemplo servirá para entender mejor la regla. Supóngase que la norma prohíbe cruzar un semáforo cuando está en rojo la señal. Obviando correctivos externos de índole administrativo (multas, talleres forzosos o trabajo social), la probabilidad de que a los transgresores de esta norma sean castigados, es apenas del $11 / 2(50 \%) ; 1 / 2$ es el margen de error en la aplicación de la norma. Acéptese un daño predeterminado de $10.000 €$, y un coste de prevención $(X)$ de $6.000 €$. El análisis de prevención (self-monitoring judgement) de un individuo ante la norma hará que se arriesgue a no cumplir la norma, para ahorrar $1.000 €$ (la diferencia entre coste de prevención y daño reconocido bajo el error, o $X-L$ ).

De aplicar la regla de la reciprocidad propuesta por COOTER, el jurado debería, para corregir el error de ejecución (e) aumentar $L$ en $\mathrm{PD}$, reconociendo por concepto de DP, $5.000 €(P D=10.000-(10.000 / 2))$.

Similar análisis puede hacerse respecto de las empresas (con independencia de su personalidad jurídica, que para estos efectos deviene irrelevante). El juicio de prevención se basa ahora en la noción de control de calidad (quality control), equivalente al self-monitoring de personas naturales; solo que el análisis de responsabilidad debe hacerse respecto de sus directivas y de los empleados o aquellas personas que ejecutan un política que reporta beneficios a la empresa.

Ahora bien, no siempre es necesario corregir el error descrito, dado que su magnitud no repercute significativamente en el desconocimiento del enunciado normativo, por ejemplo, por tratarse de mandatos sociales recogidos pacíficamente por una prescripción legal ${ }^{163}$ (nadie duda de que el matar a alguien, si bien está prohibido por la ley, es un mandato impe-

el múltiplo punitive óptimo es igual al inverso del error: $e \rightarrow m=1 / e \rightarrow m=(\mathrm{D} / \mathrm{w})[-\mathrm{p}(\mathrm{x})]$. El modelo resta sobre la presunción de que la prevención es constante y determinante en la reducción de la probabilidad del daño, así como en el ánimo racional del agente de evitar ser condenado por daños punitivos (es decir, un agente verdaderamente racional). De esta manera, el objetivo de internalización del coste social asociado al error de ejecución de la norma, solo es posible si el múltiplo punitivo iguala los daños compensatorios al coste de prevención asumido racionalmente, multiplicado por la probabilidad marginal de anticiparse al resultado dañino. Es por esto por lo que solo deben reconocerse daños punitivos cuando el agente asume un nivel de prevención considerable, es decir, cuando el error de ejecución normativo deriva un coste social excesivo; evento que no se presenta cuando, por ejemplo, el agente es un individuo solvente.

${ }^{163}$ COOTER, R., «Punitive Damages...», ob. cit., p. 86: «In general, the necessity of reciprocal damages to deterr wrongdoing depends upon the relative size of the enforcement error and the jump in liability costs at the legal standard». 
rativo internalizado socialmente como fundamental para una convivencia pacífica $^{164}$ ).

Esta regla tiene el inconveniente de la dificultad para prevalorar $D$, nada distinto a expresión emotiva de la norma (emotive expresión of rational rules) desarrollada en la Teoría de la norma de COOTER; porque, en efecto, la compensación perfecta es una utopía, tanto desde una perspectiva económica como legal de cualquier sistema normativo.

Una segunda causa de intencionalidad es descrita por COOTER como malicia (malice), es decir, aquella conducta consumada únicamente con el propósito de derivar un beneficio privado y egoísta del daño. COOTER diferencia el supuesto de beneficio psicológico (subjective satisfaction) del beneficio económico, para concluir que el primero carece de regla de tasación del daño punitivo como disuasorio ${ }^{165}$.

En relación con el segundo, debe advertirse que los criterios seguidos en el reconocimiento jurisprudencial de daños punitivos son la conducta dañina (harmful behaviour) y la disuasión (deterrence). Tales son, sin lugar a dudas, los parámetros más complejos y que han dado lugar a un considerable número de sentencias relevantes para el análisis económico del daño punitivo, cuando quiera que su cuantía exceda desproporcionadamente el monto reconocido por concepto de daños compensatorios (compensatory damages).

Un ejemplo de lo anterior es el caso Mathias V. Accor Economy Lodging, Inc. ${ }^{166}$. Del acervo probatorio se coligen los siguientes hechos. Las víctimas fueron mordidas durante su corta estadía en el «Motel 6», parte de la cadena hotelera «Accor Economy Lodging, Inc.». El demandado rehusó a fumigar las habitaciones, pese a ser advertido de tal necesidad por parte del contratista «EcoLab». Ante el creciente número de reclamos por parte de clientes afectados, el encargado del hotel optó por engañar al público, diciendo que, en lugar de pulgas, se trataba de otros insectos ${ }^{167}$ y que su proliferación obedecía a la estación del año, que nada se podía hacer, continuando con la política de devoluciones. El coste de la fumigación era mucho menor que el de las devoluciones de un mes. Pese a que el daño demostrado no era mayor que un par de días de incapacidad debido a malestar general e irritación, el jurado reconoció, en primera instancia, US\$ 5.000 por daños compensatorios

\footnotetext{
${ }^{164}$ El papel de la Filosofía del Derecho cobra aquí notoria importancia, aunque no será desarrollado por exceder el objetivo del presente estudio.

165 Cooter admite la viabilidad del Método del Riesgo Equivalente (Risk-Equivalent Method), desarrollado para compensar daños de naturaleza intangible, a la hora de valorar el beneficio psicológico que reporta el agente en esta modalidad de daños intencionales.

166 El caso puede obtenerse en la dirección online <http://www.wileyrein.com/ docs/docs/82.pdf>. 12 de octubre de 2008 .

${ }^{167}$ Como medida para no asustar a la clientela, dado que las pulgas generan un mayor temor entre el público que otros insectos, pero sin advertir que los insectos que alegaban que existían en el lugar, eran, en efecto, más peligrosos epidemiológicamente hablando.
} 
para cada víctima, y US\$382.000 por daños punitivos. La decisión fue recurrida bajo el argumento de exceso punitivo (daños punitivos 37,2 veces el compensatorio).

La apelación correspondió al famoso tratadista y juez Richard Posner, quien ratificó lo fallado por el $a$ quo, bajo el argumento de que, dadas las circunstancias del caso, es palpable que, debido al bajo monto de los daños compensatorios (hecho que lleva a las víctimas a internalizar el resultado dañino ante los prohibitivos costes judiciales), así como el desequilibrio económico de las partes (que el hotel tenía mucho más dinero para asumir el juicio), hecho que volvía prohibitivo cualquier acuerdo voluntario no transaccional, era presumible una muy baja probabilidad en la ejecución de la norma (no necesariamente legal, pues en la sentencia no se tienen en cuenta las regulaciones legales o administrativas de la industria hotelera).

Para Posner, la insuficiencia fáctica de la probabilidad de inejecución da discrecionalidad al jurado ${ }^{168}$, incluso para desconocer, en el caso concreto y sin pretensión de regla, lo establecido por la jurisprudencia relevante (o más aún, el propio mandato constitucional) ${ }^{169}$; motivo que, unido a la finalidad intrínseca de disuasión del daño sancionatorio, son suficientes para no cuestionar la decisión ${ }^{170}$.

${ }^{168}$ Mathias V. Accor Economy Lodging, Inc, p. 3: «(...) limiting the defendant's ability to profit from its fraud by escaping detection and (private) prosecution. If a tortfeasor is 'caught' only half the time..., then when he is caught he should be punished twice as heavily in order to make up for the times he gets away».

${ }^{169}$ De ser posible asumirse una determinada regla en esta modalidad de daños intencionales, no puede ser otra que la esgrimida en State Farm Mut. Auto. Ins. Co. v. Campbell: «few awards -of punitive damages-exceeding a single-digit ratio between punitive and compensatory damages, to a significant degree, will satisfy due process. (...)-it's-suggested that four times the amount of compensatory damages might be close to the line of constitutional impropriety». Nótese como esta decisión apela a criterios constitucionales de limitación del daño, concretamente la Octava Enmienda de la Constitución de los EE. UU. que reza que «no serán impuestas fianzas, multas o castigos excesivos, inusuales o crueles» (traducción al castellano propia). La Constitución de los Estados Unidos de América puede obtenerse en <http://constitutioncenter.org/files/constitution.pdf>. El case State Farm Mut. Auto. Ins. Co. v. Campbell en United States Reports, No. 538, Oct. Term 2002, «Cases Adjudged in The Supreme Court». Entrega oficial realizada el día 5 de marzo de 2008. Compilación hecha por Wagner, Frank D. United States Reports, Vol. 38, Cases Adjudged in The Supreme Court, Oct, 2002. Washington: Uncoated Printing Paper, 2004, en $<\mathrm{http}$ ://www.supremecourtus.gov/opinions/boundvolumes/538bv.pdf>, p. 408 y ss. Sobre un mejor análisis de las implicaciones constitucionales en la cuantificación de daños sancionatorios, la diferencia entre mitigation y deterrence, los límites del poder disuasorio de los jueces, entre otros, ver a COOTER, Robert D. The Strategic Constitution, ob. cit., pp. 459 a 467.

${ }^{170}$ Críticas a este caso, en Shavell, Steven. On the Proper Magnitude of Punitive Damages: Mathias V. Accor Economy Lodging, Inc. Harvard Law Review, Vol. 120, pp. 12231229, publicado en <http://www.harvardlawreview.orgissues/120/march07/shavell.pdf >. Lo relevante de las críticas de Shavell al caso, aplicables a otros casos donde se reconocen 
La tercera fuente de intencionalidad es la indiferencia del agente a la exposición indiscriminada del riesgo, debido, principalmente, a circunstancias transitorias de índole emocional (emotional states). El ejemplo planteado por Cooter es el del sujeto que celebra sin control, conduciendo en estado de embriaguez. Esta es apenas una de las modalidades de la culpa grave (reckless disregard of the safety of others). Debido a la dificultad reinante en la valoración de elementos subjetivos, COOTER propone una reformulación de la teoría de los lapsos (model of lapses) a través de la incorporación de un valor constante de valor de utilidad a la regla tradicional de la responsabilidad por culpa, arriba estudiada ${ }^{171}$.

\subsection{De los posibles correctivos a la incertidumbre}

La doctrina propone las siguientes alternativas puntuales de corrección ante la incertidumbre del daño:

\subsubsection{LA APLICACIÓN DE UN MÚLTIPLO PUNITIVO, CAPAZ DE MEDIR LA IMPROBA- BILIDAD EN LA APLICACIÓN DE LA NORMA}

La fórmula, mayormente aceptada por la literatura que analiza el Derecho de daños desde un enfoque económico, hace hincapié en la relación uti-

daños punitivos excesivos, giran alrededor de tres puntos: 1. De los hechos no se puede colegir que el agente, que es una compañía económicamente solvente, esté dispuesto a arriesgar su actividad so pretexto de evadir el juicio. Además, dado la causa del perjuicio, es natural inferir que las víctimas pueden fácilmente asociar su daño al demandado. 2. En relación con lo anterior, deben diferenciarse las víctimas vinculadas por una relación contractual, de aquellas ajenas a la actividad comercial del agente. En efecto, las primeras podrán incidir más directamente en la finalidad lucrativa de este, bien directamente (cambiando de prestador del bien o servicio), o a través de mecanismos públicos de regulación (quejas). 3. Deben, igualmente, valorarse criterios no legales (non legal criteria), tales como la reputación del demandado, de la industria a la que este pertenece, o la posibilidad de transacciones voluntarias de reembolso; para admitir que el mercado cuenta con herramientas suficientes de disuasión (el demandado terminaría internalizando los costes de prevención, de manera espontánea, ante un detrimento patrimonial ostensible, o ante la presión del gremio). Para Shavell, los daños punitivos en este caso, deben reconocerse como criterio auxiliar canalizador de la conducta dañina el mercado voluntario, pero no en detrimento de reglas jurisprudenciales ni, mucho menos, poniendo en peligro mandatos constitucionales. «Concealment... might not greatly reduce the probability of suit if-according to the factual data-. Also, it is not clear that damage of $\$ 382,000-\$ 191,000$ for each plaintiff - is needed to induce suit... (although perhaps winning might not have been easy). Lo anterior no es aplicable, según el propio autor, a otros casos renombrados como el de Philip Morris USA v. Mayola; el cual puede obtenerse en <http://www.law.cornell.edu/supct/ html/05-1256.ZO.html>.

${ }^{171}$ Ver más en CoOTER, Robert. Models of Morality in Law and Economics: Self-control and self-improvement for the «Bad Man» of Holmes. Boston University Review, Vol. 78, pp. 903-930, publicado en <http://works.bepress.com/cgi/viewcontent.cgi?article=1011\&context=robert_cooter>. 15 de octubre de 2008. 
lidad-expectativa de utilidad (privada) del daño como variables para medir el margen de error en la adecuada valoración el estándar óptimo de cuidado, $e$ (due optimal care), dejando en un segundo plano la vocación del agente para evadir la norma.

Es frecuente que el jurado infiera la vocación elusiva del agente de gravedad del daño (gross damages) o, lo que es peor, de la irrazonabilidad de su conducta, llevándoles a fijar sanciones exorbitantes.

Una plausible solución ${ }^{172}$ a la problemática de la prohibición total, como exceso de disuasión (overdeterrence), es la de obtener un múltiplo punitivo que mida directamente, y sin otras variables de incierta verificación (nada mas difícil que medir la utilidad que el agente espera derivar de su conducta), la ejecución estadística de sanciones civiles en relación con el daño real $^{173}$ (true social costs).

Pero la alternativa de Coleman, entendida como Regla del Múltiplo Individual (Individual Multiple Rule) no es fácilmente aplicable, en gran medida porque malinterpreta la fórmula tradicional expuesta por COOTER ${ }^{174}$. En efecto, COLEMAN entiende que COOTER hace recaer el problema de la probabilidad en la gravedad de la conducta, lo que termina por ahondar el problema de la incertidumbre.

El error está en entender la regla como un múltiplo inferior a uno (como divisor) lo que hace que, a mayor probabilidad, menor sea el múltiplo punitivo; nada más contrario a la descripción que hace COOTER de su fórmula, como un número mayor a uno. A favor de ColEMAN, está el hecho de que la regla de CoOTER está pensada para daños punitivos relacionados con la gravedad de la conducta y no con la probabilidad de evasión de la norma; motivo por el cual se incluyen las otras variables. En su contra,

172 Solución que también es aplicable a las denominadas negligencias intencionales. Ver más en Posner, Richard A. El análisis económico del Derecho. Ed. Fondo de Cultura Económica. México: 1998, pp. 198-202.

${ }^{173}$ Es decir, qué porcentaje de las condenas compensatorias se han efectivamente pagado, en relación directa con los costes sociales del daño (no solo los perjuicios de la víctima, sino además los costes procesales, rubros a terceros no tenidos en cuenta, etc.). Solo así será posible medir el correctivo sancionatorio de conductas no disuadibles bajo un modelo de culpa simple (negligence). Esta solución parte de la necesidad de daños punitivos, no en relación directa con la intencionalidad de la conducta dañina, sino con la predisponibilidad del agente para asumir el coste del perjuicio (diferencia entre la probabilidad de no condenar a un culpable, como de culpa a un inocente); o mejor dicho, la inoperancia misma del modelo subjetivo tradicional de responsabilidad, ante cierto tipo de daños.

${ }^{174}$ COLEMAN critica la fórmula de COOTER en los siguientes términos «Even when probability of punishment is less than one, if that probability declines as defendants take more care, then defendants may tend to overcomply. In such a case, increasing the expected fine or damage award would only increase overdeterrence, exacerbating the problem rather than curing it». CALFEE, John E. \& CRASHWEll, ob. cit. p. 218. 
puede sostenerse la dificultad empírica para hallar los múltiplos punitivos individuales.

Parece como si COLEMAN evadiera la anterior observación al afirmar que los múltiplos punitivos, más que individuales, son temáticos (o por categoría de daños), y que no vienen dados de manera diferenciada sino constante; como en el caso del múltiplo triple que consagra la normativa antitrust norteamericana. Sin embargo, el problema de la overdeterrance de COLEMAN, se resolvería si se comprendiese que el daño intencional suele darse en individuos con un nivel inferior de sensibilidad y respeto a la norma, es decir, más indiferente al castigo ${ }^{175}$.

\subsubsection{LA FIJACIÓN DEL ESTÁNDAR DE RESPONSABILIDAD ${ }^{176}$ EN EL PUNTO INTER- MEDIO ENTRE EL COSTE MARGINAL Y UTILIDAD}

Para COLEMAN, la incertidumbre genera que la localización del estándar legal solo sea posible como probabilidad ${ }^{177}$. Ello lo lleva a proponer que dicho estándar debería establecerse artificialmente por encima o por debajo del nivel óptimo de prevención para cada modelo de responsabilidad.

${ }^{175}$ El mayor inconveniente radica en aquellos supuestos de intencionalidad por equivalencia, como la culpa grave (reckless) o daños socialmente beneficiosos aunque con ausencia de mecanismos redistributivos de utilidad, donde el individuo, socialmente afecto por la norma, la incumple por otros motivos; aunque este múltiplo punitivo solo se refiera a casos de escape de la norma (no de otras variables). Así las cosas, se entiende que ColEMAN hable de un múltiplo inferior a uno, lo cual explica su preocupación ante la consecuente ovecompliance; y que las variables de COOTER son más complejas (valoración de daños intangibles, conducta dolosa, daño masivo, etc.). En efecto, CoLEMAN propone reducir el daño en el detrimento marginal que supone una mayor prevención por miedo a la incertidumbre, aunque esta solución no puede entenderse como limitada a todas las causas de incertidumbre, sino solo de aquellas generadas por la irresponsabilidad del agente. Una solución estandarizada sería reducir la sanción fija (en una cantidad predeterminada o determinable a través de un múltiplo sancionador fijo) en el detrimento marginal derivado de la mayor prevención (CALFEe, John E. \& CRAShwell, ob. cit. p. 219). Sin embargo, esta solución dista de ser fácil y objetivamente aprehensible, dado que en la práctica la determinación del estándar de cuidado no es necesariamente eficiente (así no existiese incertidumbre). El problema de la reducción no punitiva (compensación por la mayor prevención, contrario al castigo por la undercompliance o el dolo) no es viable en casos de daños intencionales, porque la no compensación por la mayor prevención no elimina el beneficio derivado de la acción dañina, la cual no sancionatoriamente amortizada (el agente consumará el daño, con independencia de si gana o no el incentivo de no hacerlo, si sabe que no habrá sanción y que a lo sumo tendrá que pagar el coste real del daño, sea cual fuere el nivel de certidumbre en la ejecución de la norma).

${ }^{176}$ Como por ejemplo, el de cuidado óptimo (reasonable due care), en el modelo de culpa simple (negligence).

${ }^{177}$ CALFEe, John E. \& CRASHWEll, ob. cit. p. 220: «In the real model, legal standards are more like the quarks and other basic particles studied in particle physics, which have no definite location and can only be expressed as a distribution of probabilities». 
Así, por ejemplo, en un modelo de responsabilidad objetiva (strict liability), donde la conducta del agente es irrelevante (bajo el supuesto de inaplicación de daños punitivos), y debido a que la tendencia es hacia la undercompliance, el estándar de cuidado debería fijarse por encima del ideal (optimal care); por su parte, frente a daños intencionales, donde la tendencia es hacia la overcompliance (obviando el que los agentes de este tipo de daños sean difícilmente disuadibles), lo ideal sería fijar un nivel de cuidado por debajo del nivel óptimo ${ }^{178}$.

Pero, el nivel de ajuste (resultante de la distribución de probabilidades del estándar tradicional de cuidado coste-beneficio) no garantiza que el estándar así calculado sea el más eficiente. La práctica demuestra que el juego de las probabilidades es implícitamente seguido por las cortes, cuando fijan el estándar de prevención según la relación coste-beneficio del daño ${ }^{179}$ (mayor si el beneficio del daño es alto y el coste de prevención es bajo; y menor en el sentido opuesto).

\subsubsection{CORRIGIENDO LA INCERTIDUMBRE A TRAVÉS DE MECANISMOS LEGALES}

Tales como un estándar fijo de cuidado, pretasación de daños, mejor recopilación de pruebas o la internalización de costes mayores o menores de prevención que no sigan el nivel preestablecido. El inconveniente estriba en que, además del mayor coste administrativo implícito en la implementación de tales medidas, surge la necesidad de modificar los estándares, cada vez que el contexto social varíe (por ejemplo, si se establece como límite de velocidad $60 \mathrm{~km} / \mathrm{h}$, y por cada $\mathrm{km}$ adicional se prevé un aumento determinado del daño, cuando se construyan mejores vías de comunicación, se deberá modificar la norma a la nueva realidad), lo que a su vez aumentará los costes del sistema; por no mencionar el abandono de la más notoria ventaja del Common Law respecto del Derecho continental, como lo es la flexibilidad de adaptación con que cuenta el precedente ${ }^{180}$.

\section{Eficiencia económica de las reglas de responsabilidad convencionales}

Determinar la eficiencia de las reglas convencionales de responsabilidad del transportista en supuestos de muerte y lesiones de pasajeros entraña un alto riesgo de superficialidad, habida cuenta de los múltiples factores que

${ }^{178}$ Lo que se traduciría en una reducción del rubro punitivo como consecuencia de la previa reducción del daño compensatorio (variable usualmente considerada en la fórmulas estudiadas), por cuanto si el estándar de cuidado se infravalora, el agente solo debería internalizar el coste marginal del daño (de aplicarse la incremental damage rule).

${ }^{179}$ Calfee, John E. \& Crashwell, ob. cit., p. 219-221.

${ }^{180}$ Calfee, John E. \& Crashwell, ob. cit., p. 221 y 222. 
han condicionado su negociación. Por su parte, valorar la adecuación contributiva de cada uno de dichos factores, implicaría una tarea de monumentales dimensiones, que de lejos escapa las pretensiones del presente estudio. Por ello, solo será posible limitarse al análisis económico aislado de la eficiencia de tales reglas, pero literalmente interpretadas.

Como se tuvo la oportunidad de estudiar en el acápite anterior, la eficiencia de toda regla de responsabilidad debe ser valorada en razón de la manera como logre distribuir los riesgos entre los actores de la relación jurídica, tanto contractual como extracontractual. Esta distribución será económicamente válida si tiene en consideración sus posibilidades reales (e incluso, potenciales) de prevención, como criterio principal, y la capacidad de acceso probatorio, como criterio secundario. Lo anterior, bajo el entendido de racionalizar recursos, disminuir el riesgo, y maximizar la utilidad marginal; entendida esta como la suma de utilidades individuales, restadas en los costes directos e indirectos de la transacción.

El análisis económico del Derecho parte de que el mercado es suficientemente eficiente como para únicamente justificar su intervención pública en casos puntuales. La debilidad estructural de cada mercado referenciado, y no intereses individuales y/o sectoriales, justifican, per se, el intervencionismo externo (proveniente de un agente que se ubique por fuera del mercado).

Traduciendo estos derroteros interpretativos, debe pasarse a su concreción en la relación contractual (o extracontractual) configurada alrededor del transporte internacional aéreo de personas. En primer lugar, es claro que un porcentaje considerable del riesgo aeronáutico escapa de la esfera de control del primer llamado a obtener beneficios de la actividad, entiéndase el transportista (la utilidad del pasajero, aunque eventualmente cuantificable, se presenta en un primer momento como no pecuniaria). La compleja operatividad de la industria, en la cual intervienen muchos actores (transportistas de hecho, personal aeroportuario, técnicos no dependientes del transportista, agentes públicos de control, etc.), además de particularizar el transporte aéreo como realidad sui generis, dificulta la tarea de delimitar el ámbito de control de cada uno de ellos. Es así, como no todo riesgo podrá ser eficientemente asumido por quien los crea, ni siquiera por quien se beneficia de él.

Desde esta óptica (la del control del riesgo), el régimen de responsabilidad objetiva puro (sin matices) del transportista no es viable; además, porque la adjudicación del riesgo sería demasiado oneroso y por demás ineficiente. La complejidad descrita sí que justifica la regla de la solidaridad; y en esto de estimarse parcialmente incongruente el Derecho convencional (tanto el anterior SV como el actual CM 1999); por cuanto este no extiende la solidaridad a los otros actores de la relación jurídica. Tal yerro es parcialmente subsanado por la exigencia de un seguro y, para evitar injerencias públicas de índole subvencionistas (lo que sería una regulación exagerada del mercado que dificultaría la finalidad de uniformidad), en lugar de obli- 
gar el pago público de primas, limita la responsabilidad base del obligado a suscribirlos, es decir, el transportista.

En este único entendido (al menos desde una visión meramente económica y no garantista), tiene validez la limitación resarcitoria. En efecto, tienen razón quienes, consciente o inconscientemente, pregonan la función niveladora de la limitación convencional, relativa a la objetividad. Pero, además, debe apreciarse otro criterio que explica, paralelo a la solidaridad, la objetividad inicial del modelo: el pasajero es el menos indicado para invertir en prevención, por cuanto su esfera de control es completamente ajena al riesgo propiamente aeronáutico. Con todo, tanto el SV como el CM 1999 admiten la exoneración del transportista, total o parcial, y en cualquier momento de ejecución contractual, cuando se acredite concurrencia culposa o dolosa del pasajero. Nada más acorde con la teoría de asunción mínima de prevención, como medida económica de no agravación del daño. En consecuencia, el pasajero procurará no incidir negativamente, no solo en la generación del daño, sino también en la no extensión de sus efectos.

Algo que sí que no encuentra mayor sustento económico es la graduación de la limitación objetiva de responsabilidad. ¿Por qué 100.000 DEG, y no 150.000, por ejemplo? Esta es una de aquellas situaciones en que el Derecho coadyuva a la economía, como canalizador de factores interdisciplinarios. Aunque podría argüirse que tal cifra fue calculada en criterios vectoriales de sostenibilidad del sector asegurador, su valoración sería puramente económica.

Debido a las fuentes externas (condiciones atmosféricas), e internas (las compleja estructura de la actividad aérea, arriba explicadas) incrementadoras del riesgo, no sería descartable la solución del texto original del CV 1929, de no ser por la excesiva carga probatoria que se hacía recaer sobre el pasajerovíctima (dolo o culpa grave). En consecuencia, la propia complejidad técnica del transporte tornaba nugatoria dicha posibilidad. Las posteriores modificaciones configurativas del SV corrigieron la ineficiencia original, aunque parcialmente.

Parecería que el CM 1999 recoge las «recomendaciones» de la teoría económica: responsabilidad objetiva ante la sustancial imposibilidad del pasajero de controlar el riesgo; culpa presunta no cualificada por encima de los límites resarcitorios, como respuesta a la excesiva onerosidad de implicaría transmitir la carga probatoria de elementos de imputación subjetivos al pasajero (además de que el transportista tampoco tiene absoluto control de su actividad; es decir, es creador parcial del riesgo); y liímites indemnizatorios que, además de coadyuvar los argumentos previos, facilita la socialización del riesgo a través del seguro.

No obstante, lo que sí es económicamente ineficiente, es la naturaleza exclusivamente reparadora del modelo. Se ha analizado ya a profundidad la importancia de emplear, en supuestos tasados (y aplicando los correctivos a la incertidumbre del sistema jurisprudencial del Common Law), y previa 
delimitación estatutaria, la responsabilidad civil para materializar políticas públicas de control social. Obviando estas, la racionalización de recursos de prevención solo es posible si se reconoce la admisibilidad ${ }^{181}$ de daños no indemnizatorios («punitivos» o como quiera llamarse).

La tesis contraria alega incompatibilidad jurídica de la institución civil punitiva, adecuadora o correctiva, propia del Common Law, con la tradición del sistema continental; además de la necesidad de prevenir prácticas tecnicistas, meramente procedimentales, que pudiesen atentar contra la uniformidad tan anhelada: el bad forum shopping. No obstante, se ha demostrado plenamente que uniformidad, como símbolo de seguridad jurídica, y cohesión social y económica entre naciones, no es más que una utopía.

\section{Conclusiones-futuro de la convención y propuestas de reforma}

Para no ser reiterativos, solo resta complementar el acápite anterior, en tres puntos concretamente: remisión legeforista, límites indemnizatorios y alocación del riesgo.

A manera de conclusión, se sugieren las siguientes reformas del Modelo de Responsabilidad Convencional del transportista para los eventos de muerte o lesiones del pasajero; para poder imprimirle una mayor uniformidad al CM 1999, y garantizar su éxito futuro y su eficiencia económica. Primero, incrementar la precisión de las remisiones legeforistas, en especial los rubros del daño que son indemnizables. Tal precisión bien podría darse de manera negativa, por ejemplo, excluyendo taxativamente los rubros no reconocibles por interpretación autóctona (y que los demás sean admisibles). A manera de ejemplo, son divergentes las interpretaciones jurisprudenciales relativas a admisibilidad de rubros no materiales del daño (daño psíquico o moral). No obstante, debe defenderse la tesis de incorporación de elementos extra-resarcitorios del daño, como criterio de eficiencia económica del sistema, aunque bien precisados en aspectos tales como su definición, cuantía y límites.

Segundo, los límites indemnizatorios siguen siendo injustificadamente bajos. Los argumentos relacionados con la socialización privada de los riesgos (seguro privado), y la consecuente desregularización pública del mercado, como condicionante de políticas de liberalización económica (rechazo a las subvenciones estatales), devienen incongruentes con la actual bonanza económica del sector, sobre todo en los países más ricos, donde precisamen-

${ }^{181}$ No contradice esta postura la sostenida al comienzo de este trabajo, por cuanto lo que incentiva el forum shopping no es la admisibilidad o inadmisibilidad del daño intencional por parte del Régimen Convencional; sino su desconocimiento (que aunque aislado, existente) por Ordenamientos Estatales que reconocen los «daños punitivos» (aunque bajo la acepción no «sancionatoria»), o cualesquiera rubros espaciales del daño (no reconocidos por la mayoría de los otros Ordenamientos). Ver pie de pág. 56 
te se ejerce mayor presión por parte de asociaciones de usuarios. Se ha comprobado que el CM 1999 es poco innovador en la materia, al recoger modificaciones ya previstas en instrumentos anteriores; permanece así la principal causa del cisma y posterior ruptura del SV.

Tercero, sí que parece lógico extender la solidaridad a otros actores de la realidad aeronáutica, que contribuyen (unos más, otros menos) en la creación del riesgo. En efecto, no tiene sentido que la objetividad se endilgue únicamente al transportista durante el período de espera en sala, el cual, se ha visto, es uniformemente interpretado como parte del «embarque» en «medida en que este pueda ejercer control del pasajero». El ámbito natural de prevención (aquel que puede darse a un menor coste) no corresponde, en este ejemplo, al transportista más que al personal que administra el aeropuerto; por lo que se le debe extender, al menos durante este lapso, la solidaridad mencionada. Otro tanto, y para cada supuesto específico, podría alegarse de autoridades públicas de control, contratistas externos de mantenimientos de pistas de despegue, etc.

\section{Bibliografía}

AREAl LudeÑA, Santiago. «El contrato internacional de transporte aéreo», en Curso de contratación internacional (A.L. Calvo Caravaca y J. Carrascosa González -dirs.-). Madrid: Colex, 2. ${ }^{a}$ ed., 2003, pp. 759803.

- El seguro aeronáutico. Especial referencia a la responsabilidad del fabricante de productos defectuosos. Madrid: ed. Colex, 1998.

Botana Agra, M. La ilimitación de la responsabilidad del transportista aéreo comunitario por daños a los pasajeros en caso de accidente: un estudio del Reglamento (CE) 2027/1997. Madrid: Ed. Marcial Pons, 2000.

Brown, John P. «Economic theory of liability rules». En Economic Analysis of the Law: Selected Readings. Editado por WitTMAn, Donald A. Oxford: Blackwell Publishing, 2003, pp. 34-42.

CALABRESI, Guido. El coste de los accidentes: análisis económico y jurídico de la responsabilidad civil. Traducida por BISBAL, Joaquín. Barcelona: Ed. Ariel: 1984.

Calvo Caravaca, A. L \& Areal Ludeña -edit.-. Seminario Sobre Derecho Aeronáutico. Madrid, 13-14 de Mayo de 1998. Madrid: Universidad Carlos III de Madrid y Boletín Oficial del Estado, 1999.

Calvo Caravaca, A. L \& Carrascosa González. «Desregularización del sector aéreo y Derecho comunitario», CDP, N. ${ }^{\circ} 4,1998$, pp. 9 y ss.

CALFEE, John E. \& CRASHwell, Richard. «Some effects of uncertainty on compliance with the legal standards». Virginia Law Review, Vol. 70, pp. 965-1003. En Coleman, Jules \& LANGE, Jeffrey. Law and Economics, Vol. I. Cambridge: Ed. Dartmouth, 1992, pp. 187 a 229. 
Coleman, Jules. Markets, Morals and the Law. New York, Oxford University Press \& Yale Law School Press, 2003.

COOTER, Robert. «Models of Morality in Law and Economics: Self-control and self-improvement for the "Bad Man" of Holmes». Boston University Review, Vol. 78, pp. 903-930, publicado en <http://works.bepress.com/ cgi/viewcontent.cgi?article $=1011 \&$ context=robert_cooter $>$. Fecha de consulta: 10 de octubre de 2008.

- «Punitive damages for deterrence: when and how much». Alabama Law Review, Vol. 40, Spring 1989, No. 3, p. 73, en <http:// works.bepress.com/cgi/viewcontent.cgi?article $=1097 \&$ context=robert cooter>. Fecha de consulta: 10 de octubre de 2008.

- «Punitive damages, social norms, and economics». En Law and Contemporary Problems, Duke University, School of Law Journal. Vol. 60, summer \& autumn 1997, No. 3. \& 4. <http://works.bepress.com/cgi/ viewcontent.cgi?article $=1013 \&$ context=robert_cooter $>$. Fecha de consulta: 10 de octubre de 2008.

- The Strategic Constitution. Cambridge: Princeton University Press, 2000, Chapters 12 y 14, pp. 434-440, y 512-521. Publicación online en $<$ http://works.bepress.com/cgi/viewcontent.cgi?article=1039\&context=r obert_cooter>. Fecha de consulta: 10 de octubre de 2008.

COOTER, Robert \& Ulen, Thomas. Derecho y economía. Traducida por SuÁREZ, Eduardo L. México: Ed. Fondo de Cultura Económica, 1998.

DE CuPIs, Adriano, El daño, teoría general de la responsabilidad civil. Barcelona: Ed. Bosch, 1996.

De Paz Martín, Jesús. La responsabilidad en el transporte aéreo internacional: de Varsovia (1929) a Montreal (1999). Universidad de CastillaLa Mancha. Madrid: Ed. Marcial Pons, 2006.

De Querol A., Nuria. Análisis económico del Derecho: teoría y aplicaciones. Revista Colección Derecho, Vol. 2. España: Ediciones FIEC, 2007.

DiEDERIKS-VERSCHOOR. An introduction to air law. Amsterdam: Ed. Kluwer Law International, 8. ${ }^{a}$ ed., 2006.

DíEz-Picazo, L. El Derecho de daños. Madrid: Ed. Civitas, 1999.

FRIEDMAN, David D. Law's Order: what Economics has to do with Law and why it matters. Princeton, New Jersey: Princeton University Press, 2000.

García Matamorros, Laura. «El concepto de los daños punitivos o 'Punitive Damages'». Revista Estudios Socio-Jurídicos, vol. 5, No. 001, Universidad del Rosario, Bogotá: 2003, en <http://dialnet.unirioja.es/servlet/articulo? codigo=2315022> . Fecha de consulta: 10 de octubre de 2008.

Giemulla/SCHMID -edit-. Montreal Convention. Amsterdam: Ed. Kluwer Law International, 2006.

IpPOLITO, Richard A. Economics for Lawyers. New Jersey: Princeton \& Oxford University Press, 2005.

LANDES, William M. \& Posner, Richard A. The economic structure of Tort Law. Cambridge: Harvard University Press, 1987. 
Larsen, Paul B.; Sweeney, Joseph C.; y Guillick, John E. Aviation Law: cases, laws and related Sources. New York: Ed. Transnational Publishers, Inc, 2006.

Maden, M., Stuart y Boston, Gerald W., Law of environmental and toxic torts, cases, materials and problems. Cambridge: Ed. Thomson West, 2005 , pp. 240 y ss.

MALlOY, Robin P. Law and Economics: a comparative approach to theory and practice. St. Paul, Minn., USA: West Publishing Co., 1990.

MAPELLI, E. El contrato de transporte aéreo internacional. Comentarios al Convenio de Varsovia. Madrid: ed. Tecnos, 1968.

MARTíN-CASALS, Míquel. «Spanish product liability today -Adapting to the new rules». En Products liability in comparative perspective. Editado por Duncan, Fairgrieve. New York: Cambridge University Press, 2005.

MENÉNDEZ M. Adolfo -dir.-. Régimen jurídico del transporte aéreo. Navarra: Ed. Aranzadi, 2005.

Moller, Erik, Pace, Nicholas M., \& CARrol, Stephen J. Punitive damages in financial injury, and its implication for the industrial economies: jury veredicts. Institute for Civil Justice. Washington: Ed. Rand, 1997. Versión virtual en <http://www.rand.org/pubs/testimonies/2006/CT143.pdf>. Fecha de consulta: 20 de octubre de 2008.

Pizarro, Ramón Daniel. Derecho de daños. Ed. La Roca, Buenos Aires: 1996, pp. 287-337.

Polinsky, A. Mitchell. An introduction to Law and Economics. Third Edition. New York: Aspen Publishers, 2003.

Polinsky, A. Mitchell \& Shavell, Steven. «Punitive damages: an economic perspective». En Litigation services handbook, Chap. 13, Third Edition. Ed. Roman L. Weil, Michael J Wagner, Peter B. Frank, John Wiley \& Sons, 2001. Versión virtual en <http://www.law.harvard.edu/faculty/shavell/pubs.php>.

PoSNER, Richard A. El análisis económico del Derecho. Ed. Fondo de Cultura Económica. México: 1998, pp. 198 a 202.

RuBIo, Mauricio. Economía jurídica: introducción al análisis económico del Derecho. Bogotá: Ed. Universidad Externado de Colombia, 2007, pp. 578 a 622.

RUEDA VALDIVIA, Ricardo. La responsabilidad del transportista aéreo en la Unión Europea. Granada: Ed. Comares, 2002.

SANTOS BRIZ, «Unidad del concepto de culpa civil», en Perfiles de la responsabilidad civil en el nuevo milenio. Madrid, Dykinson, 2000,

SHAVELL, Steven. «A note on marginal deterrence». International Review of Law and Economics, Vol. 12, Sept. 1992, pp. 345 a 355, Harvard Institute of Law and Economics. Versión virtual en <http:// www.law.harvard.edu/faculty/shavell/pdf/12_Inter_Rev_Law_Econ_34 5.pdf $>$. Fecha de consulta: 10 de octubre de 2008.

— «Do excessive legal standards discourage desirable activity?» Economics Letters, Vol. 95, 2007, pp. 394-397, Harvard Institute of Law and Eco- 
nomics. Versión virtual en <http://www.law.harvard.edu/faculty/shavell/ Excessive_Legal_Standards_95_Economic\%20Letters_2007_p394.pdf $>$. Fecha de consulta: 10 de octubre de 2008.

- Economic analysis of Accident Law. Cambridge, Massachusetts: Harvard University Press, 1987.

— «On the proper magnitude of punitive damages: Mathias V. Accor Economy Lodging, Inc». Harvard Law Review, Vol. 120, pp. 1223-1229. Versión virtual en <http://www.harvardlawreview.org/issues/120/ march07/shavell.pdf $>$. Fecha de consulta: 10 de octubre de 2008.

— «Punitive damages: an economic analysis». Harvard Law Review, Vol. 111, Feb. 1998, No. 4. Disponible en HeinOnline 111, Harv.L.869 (19971998), <http://www.law.harvard.edu/faculty/shavell/pdf/111_Harvard_ Law_Rev_869.pdf $>$.

— «Uncertainty over causation and the determination of civil liability». Harvard Journal of Law and Economics, Vol. 28, Oct. 1985. Versión virtual en HeinOnline 28, J.L. \& Econ. p. 587, 1985: <http:// www.law.harvard.edu/faculty/shavell/pdf/29_Uncertainty.pdf $>$. Fecha de consulta: 10 de octubre de 2008.

- «The appeals process as a means of error correction in the quantification of punitive damages». Journal of Legal Studies, Vol. 24, June 1995, pp. 379-426. Versión virtual en HeinOnline, 24, J. Legal Stud. 379, 1999, en $<$ http://www.law.harvard.edu/faculty/shavell/pdf/66_Appeals_Process. pdf $>$. Fecha de consulta: 10 de octubre de 2008.

- «The fairness of sanctions: some implication for optimal enforcement policy». American Law and Economics Review, Vol. 2, Number 2, Fall 2000, p. 223-237, Harvard Law and Economics Institute. Versión virtual en <http://www.law.harvard.edu/faculty/shavell/pdf/2_Amer_Law_ Econ_Rev_223.pdf>. Fecha de consulta: 10 de octubre de 2008.

SierRa Gil DE La Cuesta, Ignacio. Tratado de la responsabilidad civil, Tomo I. Barcelona: Ed. Bosch: 2008.

StePHEN Dempsey, Paul. European Aviation Law. Amsterdam: Kluwer Law International, 2004.

Tamayo, J. Javier. Tratado de responsabilidad civil, Tomo II. Ed. Legis: Bogotá, 2007.

VON DEN STEINEN, Erwin. National interest and international aviation. Ámsterdam: Kluwer Law International, 2006.

Wagner, Frank D. United States Reports, Vol. 38, Cases Adjudged in The Supreme Court, Oct, 2002. Washington: Uncoated Printing Paper, 2004, pp. 408 y ss. Versión virtual en <http://www.supremecourtus.gov/opinions/ boundvolumes/538bv.pdf>, Fecha de consulta: 10 de octubre de 2008.

WERNER, Z., Hirsch. Law and Economics: an introductory analysis. London: Academic Brace Jovanovich, Publishers, 1988.

WitTMan, Donald. Economic Foundation of Law and Organization. New York: Cambridge University Press, 2006. 